
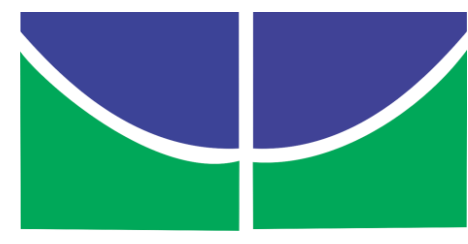

UNIVERSIDADE DE BRASÍLIA

INSTITUTO DE CIÊNCIAS BIOLÓGICAS

DEPARTAMENTO DE FITOPATOLOGIA

PROGRAMA DE PÓS-GRADUAÇÃO EM FITOPATOLOGIA

\title{
IDENTIFICAÇÃO DE VÍRUS EM TOMATEIRO ATRAVÉS DE ANÁLISE POR SEQUENCIAMENTO DE ALTO DESEMPENHO
}

THAIS PEREIRA MARTINS

Brasília - DF 


\section{IDENTIFICAÇÃO DE VÍRUS EM TOMATEIRO ATRAVÉS DE ANÁLISE POR SEQUENCIAMENTO DE ALTO DESEMPENHO}

Dissertação apresentada à Universidade de Brasília como requisito parcial para obtenção de título de Mestre em Fitopatologia pelo Programa de PósGraduação em Fitopatologia.

\section{Orientador}

Dra. Alice Kazuko Inoue Nagata

\section{Co-orientador}

Dra. Fernanda Rausch Fernandes

\section{BRASÍLIA}

DISTRITO FEDERAL - BRASIL 


\section{FICHA CATALOGRÁFICA}

Martins, Thais Pereira.

Identificação de vírus em tomateiro através de análise por sequenciamento de alto desempenho./ Thais Pereira Martins.

Brasília, 2016.

p. 117.

Dissertação de mestrado. Programa de Pós-graduação em

Fitopatologia, Universidade de Brasília, Brasília.

1. Sequenciamento de alto desempenho - Tomateiro.

I. Universidade de Brasília. PPG/FIT.

II. Identificação de vírus em tomateiro através de análise por sequenciamento de alto desempenho. 
À minha avó Maria Madalena (In memoriam) e à minha mãe Mariza Natalici, dedico. 


\section{AGRADECIMENTOS}

Agradeço a Deus pela força e proteção durante toda minha vida.

À minha mãe pelo amor, a paciência, a proteção, o carinho, as orações, e as conquistas pelas quais ela foi a maior responsável. Obrigada por ser esse exemplo de vida e essa mãe maravilhosa.

À minha irmã Marcia pela presença, a consideração e o apoio a mim concedidos desde criança. Obrigada pela força e o acolhimento nos dias difíceis.

À toda minha família pelo apoio constante nos momentos de conquista e a força no adeus a um ente querido.

À minha orientadora Alice Nagata pela oportunidade, a compreensão, os ensinamentos e a dedicação. Obrigada pelo esforço para realização desse trabalho da melhor forma possível, e pelo apoio e compreensão que foram além do ambiente de trabalho.

À minha co-orientadora Fernanda Rausch pela atenção concedida sempre que necessário e o apoio na realização deste mestrado.

Ao Dr. Erich Nakasu pelos ensinamentos essenciais à realização do trabalho e pelo esforço e preocupação em nos proporcionar o melhor ambiente de trabalho.

Ao Dr. Márcio Sanches, por me apresentar a virologia vegetal através oportunidade que me concedeu na graduação e os ensinamentos que me foram dados nos dois anos de estágio na Embrapa Cenargen.

Ao técnico do laboratório de virologia Lúcio Flávio pelos ensinamentos, conversas incentivadoras e o apoio durante a realização do trabalho na Embrapa Hortaliças.

Aos funcionários da Embrapa Hortaliças, Sr. Hamilton e Iran, pelo suporte técnico necessário à realização do trabalho.

Aos meus amigos Jéssica (também minha prima-irmã), Marcus, Jennifer, Maria Clara, Gabriela, Ritanne e Juliana pelos momentos de descontração e diversão, e pela compreensão e apoio na realização desse trabalho.

Ao meu namorado Tadeu, pelo amor, o companheirismo e a paciência durante realização desse trabalho e sempre. 
Aos meus amigos da Fitopatologia Bruno, Débora, Érica, Daniela, Carina, Sérgio, Aldemiro, Marcelo, Kamila e William, pela ajuda com as disciplinas, as conversas na hora do café da manhã e da tarde, a saidas animada e descontraídas. Obrigada por tornarem essa jornada ainda mais prazerosa!

Aos meus amigos e colegas de bancada Cristiano, Moana, Pedro, Vivian e Geane, pela ajuda diária com pequenos gestos que fazem uma grande diferença, e em especial às amigas Mônica Macêdo e Camila de Moraes, pelas conversas, ensinamentos e pelo apoio que foram indispensáveis para a conclusão desse trabalho.

Aos professores, funcionários e colegas do curso de Pós-Graduação em Fitopatologia.

Ao Centro Nacional de Pesquisa em Hortaliças - Embrapa Hortaliças pela estrutura necessária para realização deste trabalho.

Ao CNPq pelo apoio financeiro.

A todos que de alguma forma me ajudaram, meus agradecimentos. 
Trabalho realizado junto ao Departamento de Fitopatologia do Instituto de Ciências Biológicas da Universidade de Brasília, sob orientação da Dra. Alice Kazuko Inoue Nagata, com apoio do Conselho Nacional de Desenvolvimento Científico e Tecnológico (CNPq), Embrapa Hortaliças e Universidade de Brasília (UnB).

Identificação de vírus em tomateiro através de análise por sequenciamento de alto desempenho

\title{
THAIS PEREIRA MARTINS
}

DISSERTAÇÃO APROVADA em 18/10/2016 por:

Dra. Simone Ribeiro

Embrapa Recursos Genéticos e Biotecnologia

(Examinador Externo)

\section{Dr. Renato de Oliveira Resende}

Departamento de Biologia Celular da Universidade de Brasília

(Examinador Interno)

\author{
Dra. Alice Kazuko Inoue Nagata \\ Embrapa - CNPH \\ (Orientador - Presidente)
}

Dra. Rita de Cássia Pereira-Carvalho

Departamento de Fitopatologia da Universidade de Brasília

(Suplente)

\author{
BRASÍLIA - DISTRITO FEDERAL \\ BRASIL




\section{SUMÁRIO}

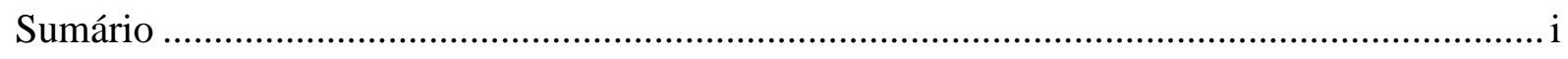

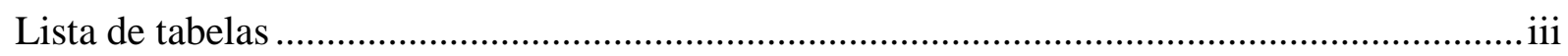

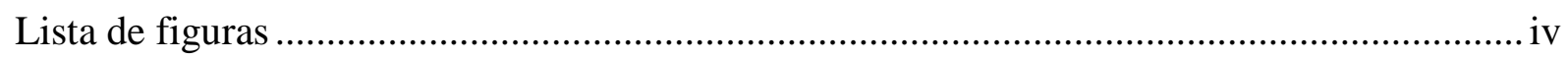

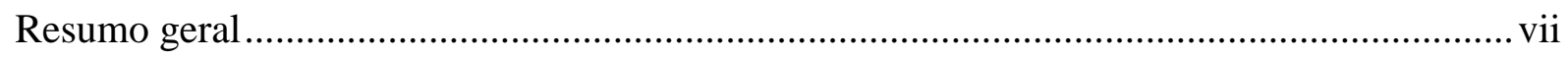

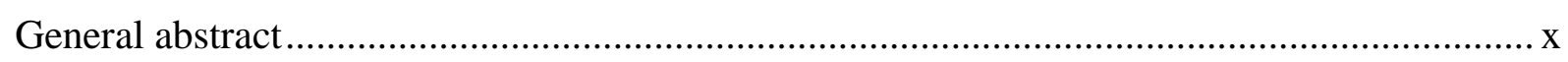

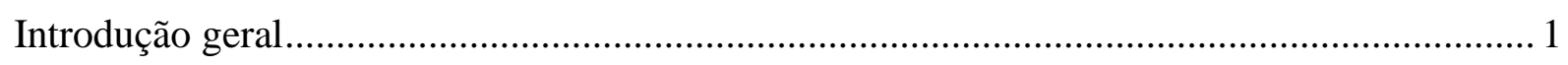

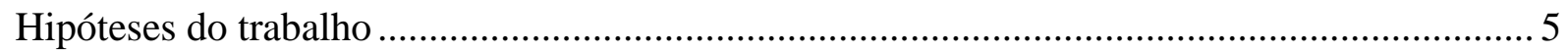

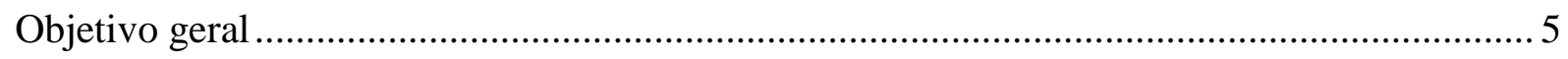

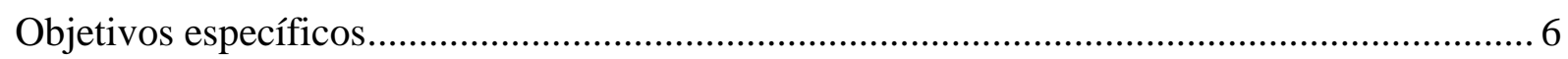

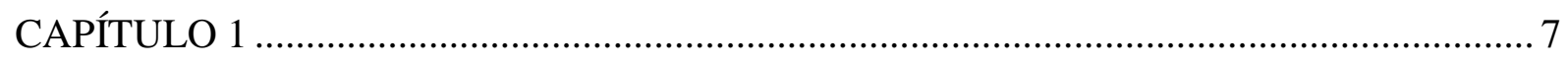

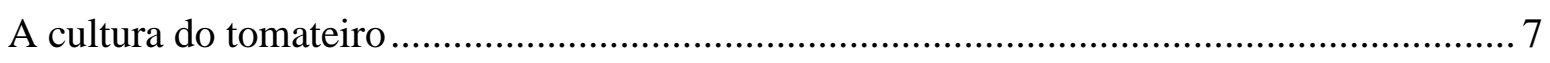

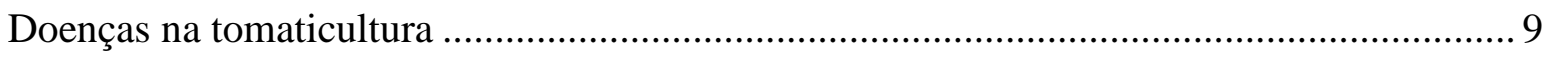

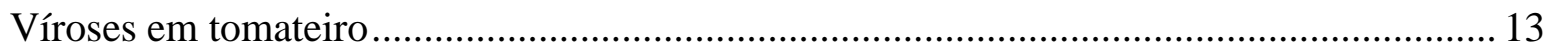

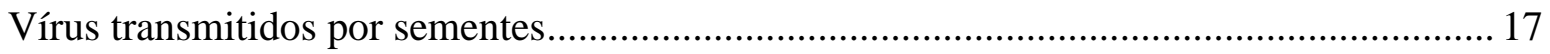

O gênero Amalgavirus e o Southern tomato virus ........................................................... 19

Técnicas tradicionais utilizadas para detecção e identificação de vírus vegetais ................. 23

Sequenciamento de alto desempenho (Next generation sequencing - NGS) ...................... 25

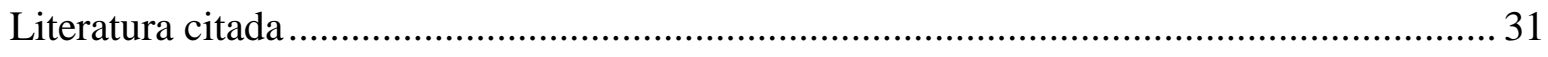

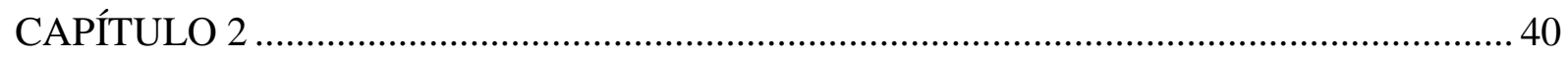

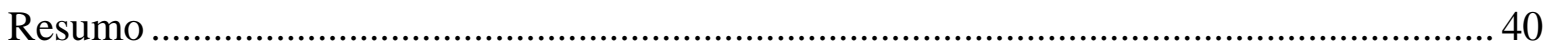

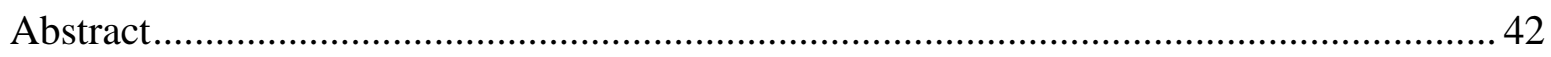

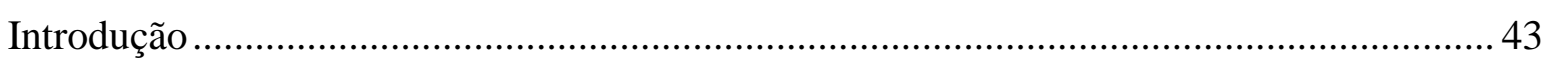

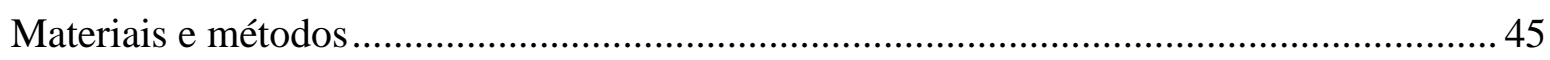

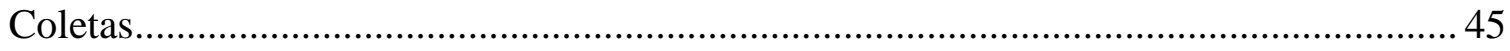

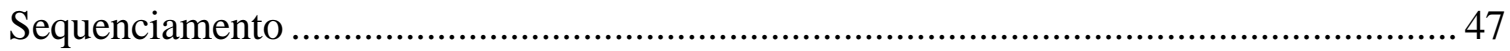

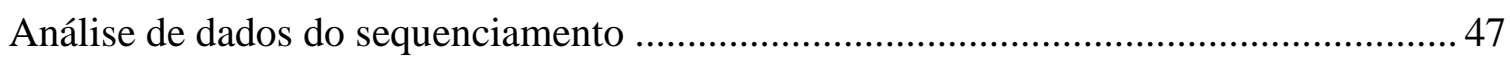

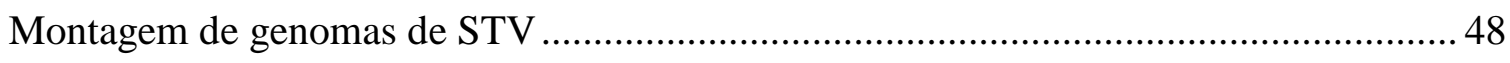

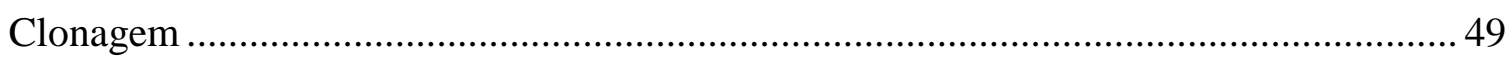

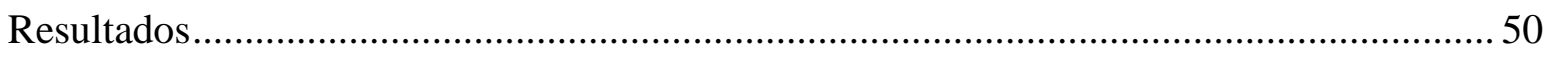

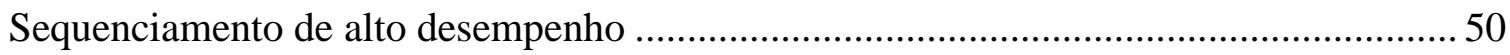

Vírus detectados por Next generation sequencing ....................................................... 50

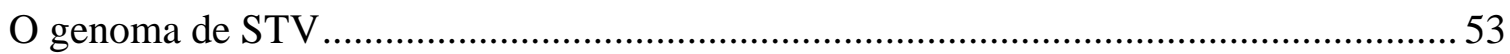




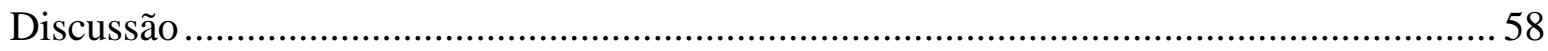

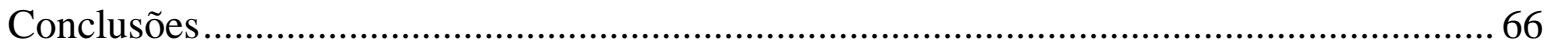

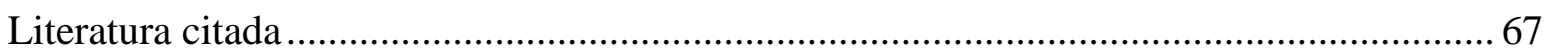

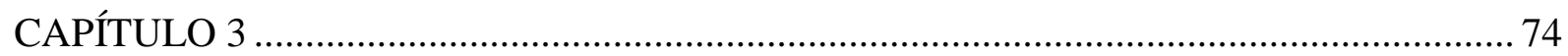

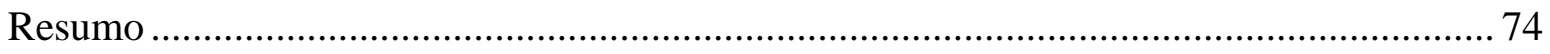

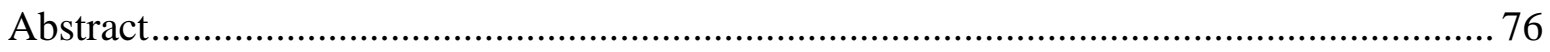

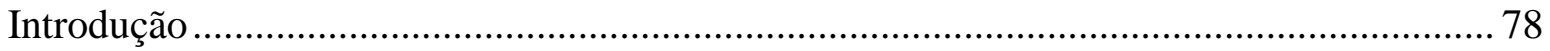

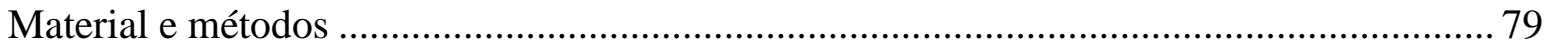

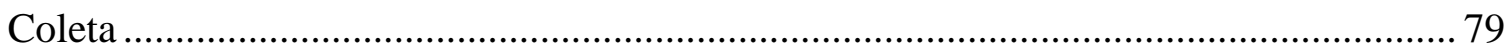

Análise filogenética da sequência genômica de Southern tomato virus ........................... 80

Germinação de plântulas de tomateiro......................................................................... 81

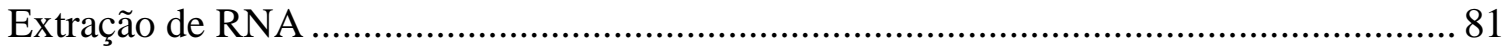

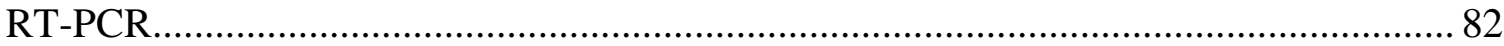

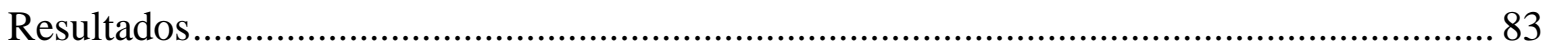

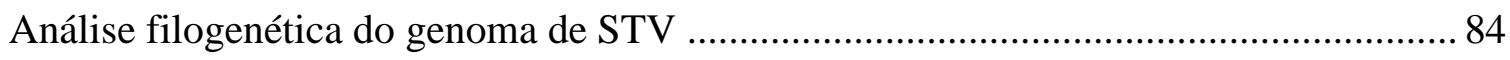

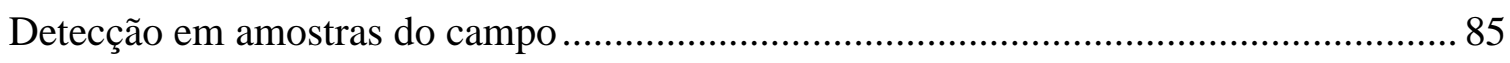

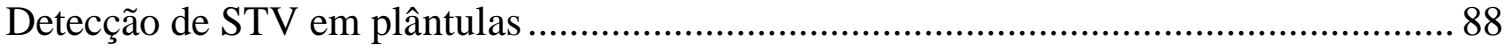

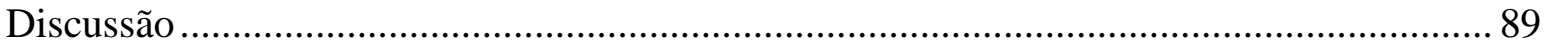

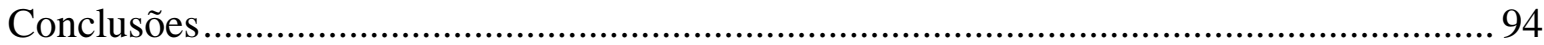

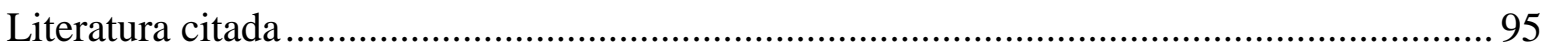

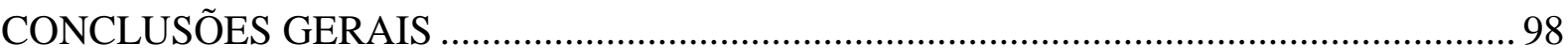




\section{LISTA DE TABELAS}

Tabela 1: Vírus que infectam tomateiro e são considerados pragas quarentenários ausentes para o Brasil.

Tabela 2: Características dos reads obtidos pelo sequenciamento de alto desempenho. 50

Tabela 3: Análise por Megablast dos contigs obtidos em cada biblioteca.

Tabela 4: Oligonucleotídeos iniciadores (primers) utilizados para a detecção de Southern tomato virus (STV) em plântulas de diferentes cultivares de tomateiro e em amostras de plantas coletadas em campo. 83

Tabela 5: Resultados obtidos na detecção de STV por RT-PCR com os pares de primers STVm e STV3, para as amostras de tomateiro coletadas em diferentes campos de produção, mostrando a quantidade de amostras positivas e amostras testadas, a incidência do vírus no local de origem e a(s) cultivar(es) coletadas.

Tabela 6: Resultados obtidos na detecção de STV por RT-PCR com par de primers STVm para as cultivares BRS Sena, H-9553, H-9992, Santa Clara. 89 


\section{LISTA DE FIGURAS}

Figura 1: (A) Produção mundial de tomate em milhões de toneladas do ano 2010 ao ano 2013; (B) dez maiores produtores mundiais de tomate no ano de 2013; (C) contribuição de cada região do Brasil para a produção nacional de tomates na safra de 2015. Fonte: IBGE, FAOSTAT, 2016. 10

Figura 2: Representação esquemática do genoma de um amalgavírus que consiste de um RNA dupla fita (dsRNA) de aproximadamente $3,5 \mathrm{~Kb}$, com duas ORFs sobrepostas que codificam uma capa proteica (CP) com massa molecular de $42,4 \mathrm{kDa}$ e uma RNA polimerase (RdRp) com massa molecular de 87,4 kDa (Adaptado de Sabanadzovic et al., 2010).

Figura 3: Representação esquemática do processo de imobilização e preparo de amostras. (A) Os fragmentos são ligados a uma superfície com primers complementares aos adaptadores, conhecida como flowcell; (B) múltiplas amplificações por PCR gerarão aglomerados de fragmentos conhecidos como clusters (Adaptado de Metzker et al., 2010). 27

Figura 4: Representação esquemática do processo de sequenciamento utilizado na plataforma Illumina. (A) Um nucleotídeo marcado com fluorescência é incorporado; (B) ocorre a lavagem para a retirada dos nucleotídeos que não foram incorporados e a obtenção de imagem de quatro cores para captação da fluorescência; e (C) clivagem é realizada para retirada da fluorescência e do grupo de inibição (Adaptado de Metzker et al., 2010). 28

Figura 5: Tomateiros coletados em Brazlândia com sintomas típicos de infecções virais como clorose (A) e manchas cloróticas, bolhosidade e rugosidade (B).

Figura 6: Etapas do processo de semi-purificação de partículas virais. (A) material foliar no almofariz após trituração em nitrogênio líquido; (B) extrato contendo o material foliar triturado e o tampão de purificação sendo filtrado em gaze; (C) aplicação de solução de sacarose a $20 \%$ no fundo do tubo contendo sobrenadante obtido após centrifugação; (D) precipitado formado no fundo do tubo após ultra-centrifugação a 33.000 rpm (rotor Ti-45).. 47

Figura 7: Gel de agarose mostrando plasmídeo p-GEM-T Easy-STV 440 DF 1 não digerido (ND) e plasmídeo p-GEM-T Easy-STV 440 DF 1 digerido com a enzima EcoRI (D). Marcador utilizado: $1 \mathrm{~Kb}$ Plus (Invitrogen). .54 
Figura 8: Representação esquemática do genoma STV-DF mostrando região sem cobertura de reads pelo sequenciamento de alto desempenho (em vermelho, do nucleotídeo 1.139 ao 1.324) e sequência obtida a partir do sequenciamento do pGEM-T easy-STV 440 DF 1, que completa a sequência de STV-DF.

Figura 9: Desenho esquemático dos genomas de STV e a cobertura dos reads obtidos para a biblioteca BRAZ (A) e CAM-RNY2 (B). (A) O fragmento longo de cor cinza representa o genoma STV-DF e os fragmentos menores representam alguns dos reads mapeados na sequencia. Os fragmentos vermelhos nas extremidades e na parte central da sequência representam regiões sem cobertura dos reads, sendo que o central possui indicação do local que foi necessário o preenchimento da sequência por meio de RT-PCR e clonagem do fragmento; (B) O fragmento longo de cor cinza representa o genoma STV-MG e os fragmentos menores abaixo representam alguns dos reads mapeados na sequência. Os fragmentos vermelhos nas extremidades representam regiões sem cobertura dos reads 56

Figura 10: Matriz de comparação em cores e com porcentagem, entre os isolados de STV do Brasil (DF e MG) e todas as sequências de STV disponíveis em bancos de dados: Carolina do Norte (acesso KT852573), Mississipi (acesso EU413670), México (acesso NC_011591), Bangladesh (acesso KT634055) e China (acesso KT438549).

Figura 11: (A) Gel de agarose a 1\% mostrando fragmento de 440 pares de bases amplificado por RT-PCR utilizando os primers STV3-F e STV3-R com as amotras originais das bibliotecas TOCA1, TOCA2, AHOL e BRAZ e o tomateiro sadio (TS) como controle negativo; (B) Gel de agarose a 1\% mostrando fragmento de 240 pares de bases amplificado a partir de RT-PCR utilizando primers STVm-F e STVm-R nas mesmas bibliotecas. $\mathrm{M}=1 \mathrm{~kb}$ plus (Invitrogen) 84

Figura 12: Árvore filogenética obtida pelo método da máxima verossimilhança. A análise envolveu sequências de nucleotídeos da RNA polimerase de quatorze isolados: STV-DF e STV MG (em vermelho); México (NC_011591); Bangladesh (KT634055); Carolina do Norte (KT852573); Mississipi (EU413670); China (KT438549); Blueberry latent vírus - BILV (NC_014593); Rhododendron virus A - RhVA (NC_014481); White clover cryptic virus 1 WCCV-1 (NC_006275), Rose cryptic virus 1 - RCV-1 (NC_010346), Vicia cryptic virus VCV (NC_007241); Fig cryptic virus - FCV (NC_015494) e Giardia lamblia virus - GLV (NC_003555). A barra indica número de substituições por sítio. .85 
Figura 13: Géis de agarose a 1\% mostrando resultados de RT-PCR com o par de primers STV3 para amostras de tomateiro coletadas em Brazlândia. (A) amostras da cultivar Serato; (B) amostras da cultivar BRS Zamir; e (C) tomate sadio - TS, negativo - N e positivo - P. Os fragmentos esperados foram de 440 pares de bases e estão marcados dentro de caixas vermelhas. $\mathrm{M}=1 \mathrm{~Kb}$ plus (Invitrogen) .86

Figura 14: (A) Foto de plântulas da cultivar BRS Sena com quatro dias de idade, sob papel filtro umedecido com água destilada, em recipiente plástico transparente; (B) Foto de plântula da cultivar BRS Sena com 10 dias de idade. .88 


\section{RESUMO GERAL}

MARTINS, Thais Pereira. Identificação de vírus em tomateiro através de análise por sequenciamento de alto desempenho. 2016. 117 p. Dissertação (Mestrado em Fitopatologia) - Universidade de Brasília, Brasília, DF.

O tomateiro é uma solanácea cultivada em várias partes do mundo, com fruto rico em compostos com propriedades antioxidantes e anticancerígenas. A tomaticultura está sujeita a várias doenças que podem limitar sua produção, diversos vírus têm sido descritos e estão amplamente disseminados nos campos de produção. As viroses estão dentre as doenças de maior importância, pois são de difícil controle e não existem produtos anti-virais disponíveis no mercado. A diagnose das espécies virais é realizada comumente por técnicas tradicionais e modernas, testes sorológicos como o ELISA e testes moleculares como a RT-PCR e a PCR são utilizados para detecção de patógenos previamente caracterizados. As limitações dessas técnicas aparecem quando se trata da detecção e identificação de um novo vírus. Identificar o agente causador de uma nova doença, onde não se tem informações sobre a morfologia, composição ou características químicas e físicas do patógeno, utilizando tais técnicas juntamente com microscopia eletrônica constitui uma tarefa difícil que pode demorar meses ou anos. Devido a essas dificuldades, novas abordagens para melhorar a identificação dos agentes causadores de novas doenças foram desenvolvidas. A abordagem metagenômica utilizando o método de Sanger gerou uma série de realizações importantes, porém, ao final do século XX, o sequencimento de alto desempenho (Next generation sequencing - NGS) foi lançado para suprir as limitações desse método. O sequenciamento de alto desempenho sequencia massalmente a população de ácidos nucleícos presentes em uma amostra, gerando sequências curtas de uma ou de ambas as extremidades, conhecidas como reads. O advento dessa forma de sequenciar transformou os estudos metagenômicos de grande escala em procedimentos práticos e de baixo custo. Com o objetivo de conhecer a população viral (viroma) e de obter genomas virais completos ou parciais, o sequenciamento de alto desempenho foi implementado para detectar patógenos virais em tomateiros de Brazlândia (DF), Campinas (SP) e Araguari (MG). Amostras de tomateiros que apresentavam sintomas típicos de infecções virais foram coletadas e agrupadas em cinco amostras compostas: BRAZ, com plantas de Brazlândia e AHOL, TOCA1, TOCA2, com plantas de Campinas e CAMRNY2, com plantas de Araguari. As amostras compostas foram submetidas ao processo de semi-purificação de partículas virais, à extração de RNA e posteriormente foram enviadas 
para sequenciamento na plataforma Illumina HiSeq2000, na Macrogen (Coréia do Sul). Diversos vírus de ocorrência habitual nos campos de produção brasileiros foram detectados: os tospovírus Groundnut ringspot virus, o Tomato spotted wilt virus; o tobravírus Pepper ringspot virus; o crinivírus Tomato chlorosis virus; os begomovírus Sida micrantha mosaic virus e o Tomato severe rugose virus; o tymovírus Tomato blistering mosaic virus; e os potyvírus Pepper yellow mosaic virus e Potato virus Y. O Pepper mild mottle virus foi detectado como um resultado inesperado, devido à predominância de tobamoviroses causadas por Tomato mosaic virus em tomateiro. Dois contigs da amostra BRAZ geraram suspeitas de existência de uma nova espécie de ilarvírus, devido a sua baixa identidade com Ageratum latent virus e Parietaria mottle virus. O amalgavírus Southern tomato virus foi detectado em todas as bibliotecas e dois genomas semi-completos foram montados (STV-DF e STV-MG). Esses genomas mostraram alta identidade de nucleotídeos entre si e com os demais isolados de STV depositados no banco de dados. O STV é um vírus de RNA fita-dupla de aproximadamente 3,5 Kbp, pertencente ao gênero Amalgavirus, que foi descrito na América do Norte (Estados Unidos e México). Não há evidências de transmissão mecânica ou por enxertia desse vírus, porém, estudos anteriores confirmaram elevadas taxas de transmissão vertical $(70 \%-90 \%)$. Os relatos desse vírus têm crescido nos últimos anos, foi relatado também na França, na Espanha, na China, na Itália e em Bangladesh. A detecção sempre em co-infecção com outros vírus e a ausência de sintomas em plantas positivas para o vírus gerou dúvidas a respeito de sua patogenicidade, porém sua alta taxa de transmissão vertical e a expansão de sua distribuição gerou preocupações para a indústria do tomate. Maiores estudos são necessários para definir o efeito de sua presença em lotes de sementes comerciais e o seu potencial de patogenicidade. Com o objetivo de caracterizar o isolado de STV encontrado no Brasil, a presença desse vírus foi confirmada e foi realizado um estudo filogenético, além da detecção por RT-PCR em plantas coletadas no campo e em sementes comerciais de tomateiro utilizando dois pares de primers. Todas as amostras compostas originais testadas apresentaram resultados positivos para RT-PCR, com ambos os primers. A clonagem e sequenciamento de fragmento gerado a partir da amostra BRAZ possibilitou a obtenção dos nucleotídeos faltantes na sequência STV-DF. A análise filogenética da RNA polimerase pelo método da máxima verossimilhança, mostrou agrupamento dos isolados de STV-DF e STVMG com as demais sequências de STV. Os isolados de STV permaneceram próximos a outros vírus pertencentes à família Amalgaviridae, que se mostraram mais próximos dos vírus da família Partitiviridae que do vírus pertencente à família Totiviridae. O vírus foi detectado em amostras coletadas em Brazlândia e Taquara (DF), em São José do Rio Preto (SP), em 
Corúmba de Goiás, Morrinhos e Goianápolis (GO) e em Reserva (PR) As plântulas testadas das cultivares Predador, Santa Clara, H-9992 e H-9553 também apresentaram resultados positivos para infecção por STV. A alta similaridade entre os isolados de STV encontrados e os existentes e a detecção desse vírus em plântulas de sementes comerciais indicam uma provável introdução do vírus através de materiais vegetais importados. Aproximadamente um sétimo dos vírus de plantas conhecidos são transmitidos por sementes de pelo menos uma espécie vegetal por ele infectada. A detecção desse vírus em plântulas oriundas de sementes comerciais demonstra a fragilidade do controle do material vegetal que entra no país. Quatorze países exportam sementes de tomate para o Brasil sem a análise de risco de pragas por estarem autorizados pelo MAPA. Embora a importação seja importante para a economia do país, a ineficiência das medidas fitossanitárias para autorizar a entrada das sementes pode trazer consequências desastrosas para agricultura brasileira.

Palavras-chave: sequenciamento de alto desempenho, STV, tomateiro, transmissão vertical. Orientadora: Dra. Alice Kazuko Inoue Nagata - Embrapa Hortaliças.

Co-orientadora: Dra. Fernanda Rausch Fernandes - Embrapa Quarentena Vegetal. 


\section{GENERAL ABSTRACT}

\section{MARTINS, Thais Pereira. Identification ofviruses in tomato by next generation}

sequencing. 2016. 117 p. Dissertation (Master in Plant Pathology) - Universidade de Brasília, Brasília, DF, Brazil.

The tomato is a solanaceous plant, rich in substances with antioxidant properties, and which is cultivated in several regions of the world. Susceptible to infection by different viruses, the tomato production has serious risks that limit its production. Viruses are among the most important diseases because of the difficulty in their control. The diagnosis of viral species is commonly carried out by traditional and modern techniques, such as serological and molecular tests such as PCR or RT-PCR, which are used to detect previously characterized pathogens. These tools have limitation in cases when there is a need for detection and identification of unknown viruses. The identification of the etiological agent of a new disease, i.e. without information on particle morphology, genome composition and chemical and physical properties, starting from electron microscopy, is a difficult task that can take months or years to accomplish. To circumvent these difficulties, new techniques were developed. The metagenomics approach, using the Sanger method, has generated a number of important achievements, but at the end of the 21 st century, high-performance sequence was launched to overcome the limitations of this method. The Next generation sequencing (NGS) strategy enables the determination of sequences of the whole population of nucleic acids present in a sample, by generating sequences of one or both ends (named reads). The advent of this sequencing technique has transformed metagenomic studies of large-scale practical and with a low cost. In order to determine the viral population (virome) and assemble the complete or partial viral genomes present in tomato plants, high-performance sequencing has been implemented in plants collected in the regions Brazlândia (DF), Campinas (SP) and Araguari (MG). Tomato samples with typical symptoms of viral infections were collected and grouped into five composite samples: BRAZ, containing plants collected in Brazlândia; AHOL, TOCA1, TOCA2 from Campinas; and CAM-RNY2 from Araguari. The composite samples were subjected to the process of semi-purification of viral particles, extraction of RNA and sequencing on Illumina platform HiSeq2000 at Macrogen, Inc. (South Korea). Several viruses commonly found in Brazilian production fields were detected, such as tospovírus Groundnut ringspot virus and Tomato spotted wilt virus; the tobravírus Pepper ringspot virus; the crinivírus Tomato chlorosis virus; the begomovírus Sida micrantha mosaic virus and Tomato severe rugose virus; the tymovírus Tomato blistering mosaic virus; and the potyvírus Pepper 
yellow mosaic virus and Potato virus Y. The tobamovirus Pepper mild mottle virus was also detected, though this result was not expected due to the predominance of Tomato mosaic virus in tomato. Two contigs generated from BRAZ sample showed a proximity to the ilarvirus Ageratum latent virus and Parietaria mottle virus suggesting the presence of a new ilarvirus in the plants. The amalgavirus Southern tomato virus (STV) was detected in all libraries and two semi-complete genomes (STV-DF and STV-MG) were assembled. These genomes showed high nucleotide identity each other and among other STV sequences deposited in nucleotide databases. STV is a double-stranded RNA virus of approximately $3.5 \mathrm{kbp}$, belonging to the genus Amalgavirus, which was described in North America (United States and Mexico). There is no evidence for mechanical transmission or by grafting of this virus, however, previous studies have confirmed high vertical transmission rates $(70 \%-90 \%)$. The reports of this virus have increased in the last years, being reported in France, Spain, China, Italy and Bangladesh. Questions regarding its pathogenicity properties are unanswered since they are usually detected in co-infection with other viruses and because of the absence of symptoms in positively infected plants. Its high rate of vertical transmission and the expansion of its worldwide spread are of big concerns for the tomato industry. Further studies are needed to define the effect of their presence in batches of commercial seeds and its potential for pathogenicity. In order to characterize the STV isolates found in Brazil, the presence of this virus has been confirmed and we performed a phylogenetic study, in addition to the RT-PCR using two primer sets, detection in plants collected in the field and in commercial tomato seeds. The original composite test samples were all positive for RT-PCR with both primer sets. The gap on the STV NGS-sequence from Brazlândia was filled by cloning and sequencing of an RT-PCR amplified fragment. The phylogenetic analysis of the RNA-dependent RNA polymerase gene by the maximum likelihood method showed grouping of STV-DF and STV-MG sequences with other STV sequences reported throughout the world. The STV sequences were closely related to viruses of other genus within the family Amalgaviridae, and to those of Partitiviridae than to those of Totiviridae. The virus was detected in new samples from Brazlândia and Taquara (DF), in São José do Rio Preto (SP), in Corumba de Goiás, Morrinhos and Goianápolis (GO), and Paraná (PR). Seedlings tested for the detection of STV of the cultivars Predator, Santa Clara, H-9992 and H-9553 were positive. The high identity among the isolates and the high incidence rate of STV in seeds indicate a possible introduction of the virus from the tomato seeds. Approximately one in seven known plant viruses is transmitted by seeds of at least one plant species. The detection of this virus in commercial seed seedling demonstrates the fragility in the control system of 
importation of plant materials. Fourteen countries export tomato seeds to Brazil without the need of risk analysis of pests because they are authorized by MAPA. Although this importation is important for the tomato production chain, the inefficiency of phytosanitary regulation system by authorizing the entry of contaminated seeds can have disastrous consequences for the Brazilian agriculture.

Keywords: next generatin sequencing, STV, tomato, vertical transmission.

Advisor: Dr. Alice Kazuko Inoue Nagata - Embrapa Vegetables.

Co-advisor: Dr. Fernanda Rausch Fernandes - Embrapa Vegetal Quarantine. 


\section{INTRODUÇÃO GERAL}

O tomateiro é uma solanácea que teve origem na América do Sul, em uma região que vai desde o Equador até o Norte do Chile. Foi introduzida no Brasil por imigrantes europeus no final do século XIX, mas sua difusão e consumo começaram por volta de 1930. Seu fruto é uma baga carnosa e suculenta, com elevada importância na dieta humana pela presença de compostos com propriedades antioxidantes e anticancerígenas (Carvalho \& Pagliuca, 2007; Alvarenga, 2013; Alvarenga \& Coelho, 2013).

A produção global do tomate duplicou nos últimos vinte anos, devido ao crescimento no consumo. Hoje ele é consierado um dos principais produtos do agronegócio, tanto em nível mundial como nacional. Em 2015, a safra brasileira foi de 3.686.000 toneladas com 56,8 mil hectares plantados. As regiões Sudeste e Centro-Oeste foram responsáveis por $69 \%$ dessa produção (IBGE, 2016).

A tomaticultura apresenta características particulares como alto custo de produção e alta suscetibilidade a doenças. Essa cultura é prejudicada por diversas espécies de fungos, bactérias, nematoides e vírus, o que reflete no aumento dos custos da produção (do Vale et al., 2013; Nascimento et al., 2013).

As principais doenças de origem fúngica são a pinta-preta, causada por fungos do gênero Alternaria (Kurozawa \& Pavan, 2013); a requeima, causada por Phytophthora infestans (Reis, 2010; Lopes \& Reis, 2011); a septoriose, causada por Septoria lycopersici (Blair \& MacNeill, 1950; Kurozawa \& Pavan, 2013); a murcha-de-fusário, causada por Fusarium oxysporum f. sp. lycopersici (Reis et al., 2004); a murcha-de-esclerócio, causa por Sclerotium rolfsii (Lopes \& Reis, 2011); o oídio, causado por Oidiopsis haplophilli e Oidiopsis lycopersici (Lopes \& Reis, 2011; do Vale et al., 2013) e o mofo-branco, causado por Sclerotinia sclerotiorum (Dildey et al., 2014). 
Dentre as doenças bacterianas, as mais importantes são a murcha bacteriana, causada por Ralstonia solanacearum (Lopes \& Reis, 2011); a podridão-mole, causada por bactérias pectolíticas do gênero Pectobacterium ou Dickeya (Lopes \& Reis, 2011); o cancro-bacteriano, causado por Clavibacter michiganensis subsp. michiganensis (Kurozawa \& Pavan, 2013); a mancha bacteriana, causada por um complexo de espécies de Xanthomonas: X gardneri. X. vesicatoria, X. euvesicatoria e X. perforans (Jones et al., 2000; 2004; Quezado-Duval \& Lopes, 2010); a pinta-bacteriana, causada pela bactéria Pseudomonas syringae pv. tomato (Kurozawa \& Pavan, 2013); e a podridão-da-médula, causada por Pseudomonas corrugata (Kurozawa \& Pavan, 2013; do Vale et al., 2013).

Os principais nematoides que constituem ameaça para a cultura do tomateiro são aqueles do gênero Meloidogyne, causadores de galhas nas raízes (Pinheiro et al., 2014), e os do gênero Pratylenchus, que provocam lesões necróticas que podem servir de entrada para fungos e bactérias (do Vale et al., 2013).

Doenças causadas por fitovírus estão se tornando cada dia mais preocupantes por se tratarem de patógenos com aumento acentuado da incidência e prejuízos econômicos expressivos. Os principais gêneros virais com espécies responsáveis por perdas consideráveis nesta cultura no Brasil são Begomovirus, Crinivirus, Tospovirus, Tobamovirus e Potyvirus (Inoue-Nagata, 2013).

A diagnose de vírus fitopatogênicos conhecidos é realizada com sucesso através da utilização de técnicas tradicionais e modernas como testes sorológicos (ELISA) e moleculares (PCR), porém, essas técnicas detectam o patógeno-alvo ou variantes próximas, sendo pouco eficientes na identificação de novos vírus. Identificar o agente causador de uma nova doença sem informações sobre a morfologia, composição ou características químicas e físicas constituia-se então em um trabalho oneroso e demorado (Quan et al., 2008; Adams et al., 2009; Wu et al., 2015). Devido a essas dificuldades, uma nova abordagem promissora 
envolvendo metagenômica e um método de sequenciamento de alto rendimento foi lançada no final do século XX e tem sido utilizada por diversos grupos de pesquisa, transformando a realização de estudos metagenômicos de grande escala em procedimentos práticos e de baixo custo (Adams et al., 2009; Barba et al., 2014).

O sequenciamento de alto desempenho feito a partir de RNA consiste na sua conversão para cDNA, segmentação desse cDNA, inclusão de adaptadores nas extremidades, ligação em superfície com primers complementares as sequências dos adaptadores, amplificação de cada fragmento para formação de agrupamentos e sequenciamento. São obtidas sequências curtas conhecidas como reads, que serão utilizados para a montagem de sequências maiores com a ajuda de ferramentas de bioinformática (Wang et al., 2009).

O rápido desenvolvimento das tecnologias de sequenciamento de alto desempenho reduziu o custo e o tempo para identificação de patógenos, levando a uma explosão de estudos metagenômicos com vírus e viróides vegetais (Wu et al., 2015).

Os vírus estão dentre os patógenos mais importantes para essa cultura devido ao aumento acentuado da incidência nos campos de produção, a dificuldade de controle e a indisponibilidade de produtos anti-virais no mercado (Inoue-Nagata, 2013). As medidas de controle mais eficientes contra as doenças virais são baseadas no princípio da exclusão, com a prevenção da entrada do patógeno na lavoura (Kimati et al., 2011). As medidas de controle baseadas nesse princípio são praticadas através de medidas quarentenárias, consolidadas em legislações fitossanitárias promulgadas por órgãos governamentais, nacionais e internacionais (Kimati et al., 2011). A importação de sementes e mudas, por exemplo, é regulada pela Instrução Normativa $n^{0}$ 06, de 16 de maio de 2005, que estabele a prévia avaliação da veiculação de pragas dos materiais (MAPA, 2005; da Silva, 2013).

Cerca de um sétimo dos vírus vegetais conhecidos são transmitidos por sementes de pelo menos uma espécie vegetal que ele infecta (Hull, 2002). A persistência desses vírus nas 
sementes por longos períodos favorece a disseminação desses vírus a longas distâncias (Sanches \& Krause-Sakate, 2013).

O Southern tomato virus é um exemplo de vírus transmitido por sementes e de difícil detecção e caracterização. Não há evidências de transmissão mecânica ou por enxertia, porém a taxa de transmissão vertical é elevada, variando de $70 \%$ a $90 \%$ de acordo com a variedade testada. Esse vírus pertence ao gênero Amalgavirus e possui genoma com RNA fita dupla de aproximadamente $3,5 \mathrm{~Kb}$ e duas fases de leitura aberta sobrepostas, que codificam a capa proteíca e a RNA polimerase (Sabanadzovic et al., 2009). Os relatos desse vírus têm aumentado nos últimos anos, com relatos na França (Candresse et al., 2013), na Espanha (Verbeek et al., 2012), na China (Padmanabhan et al., 2015), em Bangladesh (Padmanabhan et al., 2015b) e na Itália (Iacono et al., 2015). Em todos os casos, a detecção foi em coinfecção com outros vírus, o que dificulta o estudo de sua sintomatologia (Sabanadzovic et al., 2009).

Ausência de sintomas em plantas positivas causaram dúvidas com relação à patogenicidade do STV, mas sua alta taxa de transmissão vertical e o aumento de sua distribuição gerou preocupações para a indústria de tomate, que desconhece o efeito de sua presença em lotes de sementes comerciais de diversas variedades (Sabanadzovic et al., 2009; Candresse et al., 2013). Estudos que investiguem suas propriedades biológicas e moleculares são necessários para uma resposta final e conclusiva quanto ao seu potencial de patogenicidade (Iacono et al., 2015).

Este trabalho implementou a técnica de sequenciamento de alto desempenho para detectar e identificar vírus presentes em amostras de plantas de tomate supostamente infectadas, e realizar análises mais detalhadas de um vírus selecionado. 


\section{HIPÓTESES DO TRABALHO}

Existem vírus ainda não descritos no Brasil infectando o tomateiro;

É possível, através da utilização do sequenciamento de alto desempenho e da bioinformática, identificar e analisar sequências de origem viral em amostras de tomateiro;

Genomas completos de vírus presentes nas plantas amostradas podem ser montados por sequenciamento de alto desempenho;

A detecção da infecção viral pode ser realizado através de testes de RT-PCR com a utilização de oligonucleotídeos específicos;

O Southern tomato virus (STV) está presente em tomateiros no Brasil;

STV é transmissível por sementes;

É possível sua detecção em plântulas por RT-PCR;

As sementes comerciais de diversas cultivares utilizadas no Brasil estão contaminadas com o STV.

\section{OBJETIVO GERAL}

\section{Capítulo 2}

Estudar o viroma em amostras de tomate de Brazlândia - DF, Campinas - SP e Araguari - MG, através de sequenciamento de alto desempenho e com o auxílio de análises de bioinformática.

\section{Capítulo 3}

Realizar análises mais detalhadas do Southern tomato virus detectado no Brasil, através de análise filogenética e detecção em plântulas e em amostras de campo. 


\section{OBJETIVOS ESPECÍFICOS}

\section{Capítulo 2}

Identificar a população viral em amostras de tomate supostamente infectadas por vírus utilizando a técnica de sequenciamento de alto desempenho (Next generation sequencing, NGS);

Clonar e sequenciar fragmento gerado na detecção do STV;

Realizar a montagem de genoma do vírus Southern tomato virus (STV) utilizando as sequências obtidas por sequenciamento de alto desempenho e por sequenciamento do clone.

\section{Capítulo 3}

Realizar análises filogenéticas com o STV para comparação com outros isolados do banco de dados;

Definir oligonucleotídeos iniciadores para o diagnóstico viral por RT-PCR;

Detectar o vírus STV em amostras do campo e em plântulas de sementes comerciais. 


\section{CAPÍTULO 1}

\section{Revisão de literatura}

\section{A cultura do tomateiro}

O tomateiro (Solanum lycopersicum) é uma dicotiledônea que pertence à ordem Tubiflorae e família Solanaceae. Tem origem na América do Sul, em uma região que vai desde o Equador até o Norte do Chile, com temperaturas mais amenas (médias entre 15 e $\left.19^{\circ} \mathrm{C}\right)$, e altitudes mais elevadas (1.000 metros) (da Graça, 2013; Souza, 2014).

A domesticação dessa cultura ocorreu no México. No século XVI, o tomateiro foi cultivado em jardins de países europeus como ornamental, pela beleza dos frutos. O consumo iniciou-se na Espanha e na Itália e esse fruto integrou-se profundamente à gastronomia italiana, sendo amplamente usado em pizzas e saladas, com azeite, sal e condimentos. No Brasil, a introdução deve-se aos imigrantes europeus no final do século XIX, porém, a difusão e o consumo começaram por volta de 1930 (Alvarenga, 2013; da Graça, 2013).

O tipo de condução e manejo da cultura é definido principalmente pelo hábito de crescimento da planta, que pode ocorrer de duas formas. O tomateiro de crescimento determinado apresenta redução da taxa de crescimento após a emissão dos botões florais, tem crescimento limitado e é popularmente conhecido como tomateiro rasteiro. A maior parte de sua produção é destinada ao processamento agroindustrial (Alvarenga, 2013; Souza, 2014).

No tomateiro de crescimento indeterminado, mesmo após o aparecimento e desenvolvimento dos botões florais a planta continua crescendo, possibilitando a existência de frutos maduros e botões florais ainda se abrindo na mesma planta. A colheita deve ser parcelada e pode durar até quatro meses dependendo do manejo empregado, em campo aberto ou em estufas. A condução é feita com estacas ou fitilhos (Alvarenga, 2013; Souza, 2014).

O fruto do tomateiro é uma baga, carnosa e suculenta, que se desenvolve a partir de um ovário com 5 a $10 \mathrm{mg}$ de peso. Seu peso final varia de acordo com a cultivar e as condições 
de desenvolvimento (Alvarenga, 2013; da Graça, 2013). O tomate é um fruto de elevada importância na dieta humana, pois possui altos teores de vitamina A e C, e é rico em licopeno, xantofilas e carotenoides, que possuem propriedades antioxidantes e anticancerígenas. Além do valor nutricional, atributos como aparência, sabor, aroma, textura e facilidade de preparo atraem a preferência de consumo (Carvalho \& Pagliuca, 2007; Alvarenga \& Coelho, 2013; da Graça, 2013).

Nos últimos anos, o tomateiro tem sido alvo de seleções que propiciaram a melhoria da qualidade dos frutos (Alvarenga, 2013). Novas cultivares e híbridos foram lançados no mercado com características de precocidade, alta produtividade, resistência às pragas e doenças e adaptação ao ambiente (Carvalho \& Pagliuca, 2007).

Didaticamente, as cultivares de tomate podem ser divididas em cinco grupos varietais: Grupo Santa Cruz, com frutos oblongos e resistentes ao transporte, e planta com hábito de crescimento indeterminado e porte geralmente alto; Grupo Caqui, com frutos grandes de formato globular achatado e consistência mole, e planta de crescimento indeterminado; Grupo Salada, com frutos de formato também globular achatado, porém menores que os do Grupo Caqui e qualidade gustativa inferior, há cultivares com hábito de crescimento determinado ou indeterminado; Grupo Saladete ou Italiano, com frutos alongados de cor vermelha intensa e sabor adocicado, com cultivares com hábito de crescimento determinado ou indeterminado; e Grupo Minitomate, com frutos de grande variedade de cores e formatos, com tamanho reduzido e sabor adocicado, e plantas geralmente de crecimento indeterminado e porte alto, necessitando de tutoramento (Alvarenga et al., 2013).

Como um produto versátil, o tomate é usado em saladas, molhos e em receitas culinárias sofisticadas (Reetz et al., 2014). A sua produção global duplicou nos últimos 20 anos, por conta do crescimento do consumo, que foi de $14 \mathrm{~kg}$ por pessoa por ano para $19 \mathrm{~kg}$. 
O crescente consumo também está relacionado com a sua consolidação nas redes de fast food (Carvalho \& Pagliuca, 2007).

O tomate é considerado um dos mais importantes produtos do agronegócio de hortaliças, tanto em nível nacional como mundial. A produção mundial cresce a cada ano e foi de aproximadamente 152 milhões de toneladas em 2010 para mais de 164 milhões de toneladas em 2013 (Figura 1A). No ano de 2013, o continente asiático foi responsável por $60,5 \%$ da produção mundial, sendo que a China foi a maior produtora mundial, com mais de 50 milhões de toneladas. A produção brasileira neste ano ficou em oitavo lugar, com 4.187.646 toneladas em 59,9 mil hectares plantados (Figura 1B) (FAOSTAT, 2016).

Em 2015, a safra brasileira foi de aproximadamente 3.686.000 toneladas, com quase 56,8 mil hectares plantados. As regiões Sudeste e Centro-Oeste juntas foram responsáveis por 69\% dessa produção (Figura 1C). Os maiores estados produtores foram Goiás, Minas Gerais e São Paulo, com 879, 568 e 715 mil toneladas, respectivamente (IBGE, 2016).

\section{Doenças na tomaticultura}

A tomaticultura apresenta características particulares como alta suscetibilidade a doenças e custos elevados de produção. No Brasil, essa cultura é prejudicada por uma ampla gama de doenças causadas por espécies de fungos, bactérias, nematoides e vírus, refletindo no aumento dos custos, em razão principalmente da necessidade do uso intensivo de agrotóxicos para controlar a maior parte das doenças (do Vale et al., 2013; Nascimento et al., 2013; Quezado-Duval et al., 2013). 

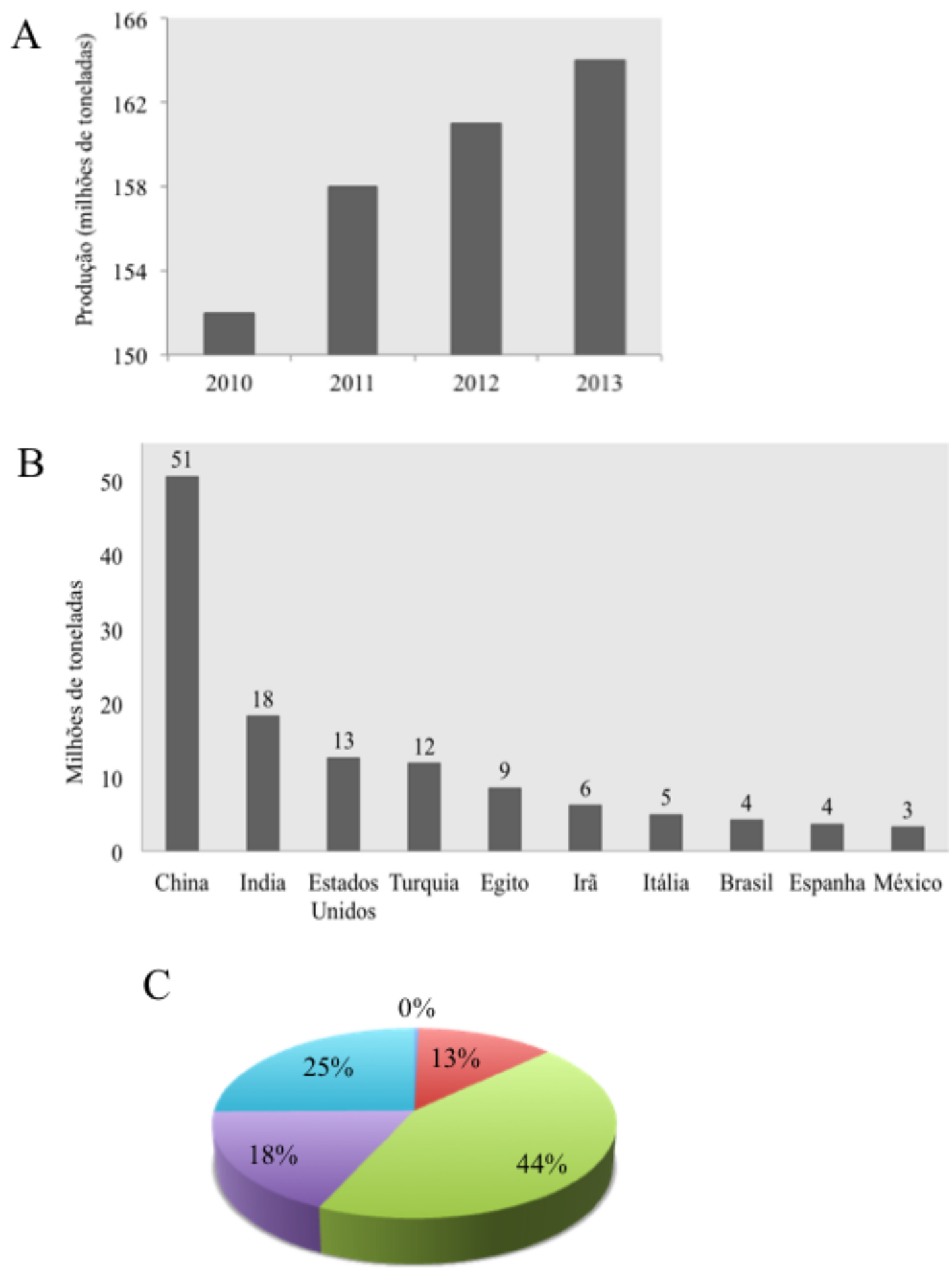

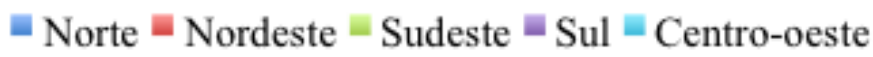

Figura 1: (A) Produção mundial de tomate em milhões de toneladas do ano 2010 ao ano 2013; (B) dez maiores produtores mundiais de tomate no ano de 2013; (C) contribuição de cada região do Brasil para a produção nacional de tomates na safra de 2015. Fonte: IBGE, FAOSTAT, 2016. 
As principais doenças fúngicas que podem atingir essa cultura são: a pinta-preta ou mancha de alternaria, causada por fungos do gênero Alternaria spp., com sintomas marcantes que consistem em manchas escuras ou pretas, de formato elíptico nas folhas e frutos (Rodrigues et al. 2010; Kurozawa \& Pavan, 2013; do Vale et al., 2013); a requeima, causada por Phytophthora infestans, forma manchas encharcadas, grandes e escuras, é altamente destrutiva e dependente de condições favoráveis como baixa temperatura e alta umidade, sendo provavelmente a doença mais importante dessa cultura em todo o mundo (Suassuna et al., 2004; Lopes \& Reis, 2011; do Vale et al., 2013); a septoriose, causada pelo fungo Septoria lycopersici, com sintomas e sinais visualizados através de pequenas lesões esbranquiçadas com bordos definidos e no centro, pequenos pontos pretos (Blair \& MacNeill, 1950; Pereira et al., 2013; Kurozawa \& Pavan, 2013); a murcha-de-fusário, causada por Fusarium oxysporum f. sp. lycopersici, com sintomas de amarelecimento intenso seguido de murcha e seca nas folhas mais velhas, progredindo aos poucos na direção das folhas novas e escurecimento dos tecidos vasculares (Reis et al., 2013; Kurozawa \& Pavan, 2013; do Vale et al., 2013); a murcha-de-esclerócio, causa por Sclerotium rolfsii, causa podridão castanha que surge próxima ao solo, a lesão se desenvolve e chega a anelar o caule, resultando em murcha repentina e permanente de toda a parte aérea da planta (Lopes \& Reis, 2011; do Vale et al., 2013); o oídio, causado por Oidiopsis haplophilli e Oidiopsis lycopersici, é muito comum em todas as regiões produtoras de tomate e caracteriza-se pela formação de um pó esbranquiçado sobre os tecidos infectados, sendo que no caso do oídio causado por Oidiopsis haplophilli tem a presença de lesões amarelas na superfície superior das folhas (Lopes \& Reis, 2011; do Vale et al., 2013) e o mofo-branco, causado por Sclerotinia sclerotiorum, cujos sintomas se caracterizam pela podridão úmida coberta por um micélio de cor branca na superfície do solo e/ou tecido hospedeiro, produzindo eventualmente estruturas de resistência denominadas escleródios (Dildey et al., 2014). 
$\mathrm{Na}$ fase de mudas, a podridão-de-colo e o tombamento-de-mudas causadas por Pythium spp., Phytophthora spp. e Rhizoctonia solani são consideradas as doenças fúngicas mais importantes, ocorre o afinamento e necrose na região do colo e pode ocorrer o tombamento ou a morte das mudas (Lopes \& Reis, 2011; Quezado-Duval et al., 2013).

As principais doenças bacterianas que são motivo de preocupação por parte dos produtores são a murcha-bacteriana, a podridão-mole, o cancro-bacteriano, a manchabacteriana, a pinta-bacteriana e a podridão-da-medula (do Vale et al., 2013). A murchabacteriana é causada pela espécie Ralstonia solanacearum e caracteriza-se por uma murcha repentina das plantas de cima para baixo e escurecimento vascular de cor marrom. A podridão-mole é causada por bactérias pectolíticas do gênero Pectobacterium ou Dickeya e provoca o apodrecimento da medula a partir dos pontos de ferimentos no caule, por onde a infecção se inicia (Lopes \& Reis, 2011; do Vale et al., 2013).

O cancro-bacteriano é causado por Clavibacter michiganensis subsp. michiganensis e apresenta sintoma característico nos frutos, conhecido como "olho-de-passarinho", com formação de lesões circulares e brancas que se rompem formando manchas redondas marrons com um halo branco (Kurozawa \& Pavan, 2013; do Vale et al., 2013).

O complexo de espécies de Xanthomonas (X gardneri. X. vesicatoria, X. euvesicatoria $\mathrm{e}$ X. perforans) causam a mancha-bacteriana em tomateiro (Jones et al., 2000; 2004). A infecção por essas bactérias causa sintomas como pequenas áreas de tecido encharcado que posteriormente necrosam nas folhas e lesões ásperas de cor parda com um halo verde encharcado nos frutos (Quezado-Duval \& Lopes, 2010; do Vale et al., 2013).

A pinta-bacteriana é causada pela bactéria Pseudomonas syringae pv. tomato e tem sintomas de lesões arredondadas e encharcadas que necrosam tornando-se pardo-escuras a preta, nos frutos são visualizadas lesões pretas, lisas e brilhantes. A podridão-da-medula é causada por Pseudomonas corrugata e seu sintoma típico é o amarelecimento das folhas, 
seguido de murcha apical e escurecimento da medula, que permanece firme, o que difere do sintoma da podridão-mole (Kurozawa \& Pavan, 2013; do Vale et al., 2013).

Dois gêneros de nematoide são considerados importantes em tomateiro no Brasil: Meloidogyne spp. e Pratylenchus spp. Os nematoides do gênero Meloidogyne spp. provocam galhas nas raízes (Pinheiro et al., 2014), que afetam a absorção e o transporte de água e nutriente para a parte aérea da planta, causando redução no crescimento, deficiência nutricional e clorose. As espécies mais comuns nos tomateiros do Brasil são M. incognita e M. javanica (Lopes \& Reis, 2011).

Os nematoides do gênero Pratylenchus spp. provocam lesões necróticas nas raízes e radicelas, mas isoladamente não se destacam como patógenos importantes. Os danos causados são indiretos, as lesões podem servir de entrada para fungos e bactérias que levam ao comprometimento do sistema radicular (do Vale et al., 2013).

\section{Víroses em tomateiro}

Doenças causadas por fitovírus estão se tornando cada dia mais preocupantes por se tratar de patógenos com aumento acentuado da incidência e prejuízos econômicos expressivos. Além disso, não existem produtos químicos que restabeleçam a sanidade de uma planta após a infecção (Inoue-Nagata, 2013). As doenças virais que ocorrem nos campos de produção de tomate brasileiros diferem de acordo com o tipo de cultivo, e a época e região também podem influenciar na ocorrência de doenças (Inoue-Nagata, 2013).

Em tomateiro rasteiro, as principais doenças que ocorrem são as begomoviroses, seguidas das tospoviroses. Em tomateiros estaqueados, a incidência varia, podendo ocorrer begomoviroses, tospoviroses, potyviroses, cucumoviroses, tobamoviroses, criniviroses e tymoviroses (Inoue-Nagata, 2013). Mais de trinta espécies de vírus podem infectar o tomateiro (Lima et al., 2015), alguns dos gêneros mais importantes e suas principais espécies serão abordados mais detalhadamente a seguir. 
O gênero Begomovirus (família Geminiviridae) possui espécies com genoma monopartido (componente único de DNA circular fita simples) ou bipartido (dois componentes genômicos, DNA-A e DNA-B). De acordo com a origem desses begomovírus, eles podem ser relacionados à begomovírus do Velho Mundo (monopartido e bipartido) e do Novo Mundo (begomovírus bipartidos) (Melgarejo et al., 2013). A transmissão dos begomovírus ocorre através do inseto-vetor, a mosca branca (Bemisia tabaci) de forma circulativa não-propagativa, porém alguns trabalhos relatam a replicação de Tomato yellow leaf curl virus (TYLCV) em insetos submetidos a condições de estresse (Pakkianathan et al., 2015).

No Brasil, os begomovírus são considerados o grupo de vírus mais importante para a cultura do tomateiro. Pelo menos quinze espécies foram relatadas infectando essa cultura, sendo que há predominância de Tomato golden vein virus - TGVV, Tomato severe rugose virus - ToSRV e Tomato mottle leaf curl virus - ToMoLCV (Fernandes et al., 2008; Albuquerque, 2012; Souza, 2014; Lima et al., 2015). A principal forma de controle de begomoviroses em tomateiro é feita através do controle químico do inseto vetor com inseticidas e da utilização de cultivares resistentes com o gene Ty-1 (Nogueira et al., 2011).

O Tomato chlorosis virus - ToCV, a única espécie de pertencente ao gênero Crinivirus (família Closteroviridae) relatada no Brasil, também é constantemente detectada em tomateiros (Barbosa et al. 2011). A infecção por ToCV apresenta sintomas fortes de clorose internerval, enrolamento foliar, folhas coriáceas e quebradiças, observados nas folhas mais velhas (Wisler et al., 1998). Estes sintomas causam danos significativos à produção, principalmente devido à diminuição da área fotossintética (Wisler et al., 1998b).

O ToCV é transmitido por moscas-brancas das espécies B. tabaci (biótipo A ,B e Q) e Trialeurodes vaporariorum, de forma semi-persistente (Wintermantel et al., 2006; Fortes \& Navas-Castillo, 2012). O controle de crinivírus em tomateiro pode ser feito através do 
controle químico do vetor, escolha de plantio em épocas com baixa população de moscabranca e eliminação de plantas daninhas hospedeiras próximas aos cultivos (Fonseca et al. 2013; Arruabarrena et a., 2015). Ainda não foram disponibilizadas no mercado cultivares com resistência a esse vírus (García-Cano et al., 2006).

A doença "vira-cabeça do tomateiro" é causada por um complexo de espécies pertencentes ao gênero Tospovirus (família Bunyaviridae): Tomato spotted wilt virus TSWV, Tomato chlorotic spot virus - TCSV, Groundnut ringspot virus - GRSV e Chrysanthemum stem necrosis virus - CSNV (Resende et al., 1996; Bezerra et al. 1999; Nagata et al., 1998). Os sintomas de infecção em tomateiro incluem arroxeamento, pontos ou anéis necróticos nas folhas e nas hastes da planta, o ápice da planta torna-se curvado, o que deu origem ao nome da doença. Os frutos podem apresentar anéis concêntricos, que desenvolvem para necrose e resultam em frutos inviáveis à comercialização (Inoue-Nagata, 2013).

Esses vírus são transmitidos por tripes dos gêneros Frankliniella e Thrips, de forma circulativa propagativa, ou seja, eles também infectam e multiplicam-se nos seus vetores (Wijkamp et al., 1995). As espécies vetoras mais importantes no Brasil são $F$. schultzei, $F$. occidentalis e T. tabaci (Nagata et al., 2004).

O "vira-cabeça do tomateiro" é manejado principalmente através da utilização de materiais com o gene $S w-5$, capaz de proporcionar resistência a todas as espécies de tospovírus que infectam o tomateiro (Stevens et al., 1992). Contudo, a durabilidade desse gene de resistência está em risco, devido ao surgimento de isolados de TSWV capazes de superar a resistência conferida por esse gene (Aramburu et al., 2010).

A principal espécie do gênero Tobamovirus que infecta o tomateiro é o Tomato mosaic virus (ToMV). Frequentemente o ToMV causa infecções latentes, mas estirpes severas podem induzir mosaico, bolhosidades, enrolamento, rugosidade, redução e afilamento do limbo 
foliar, epinastia dos folíolos e ausência de sementes nos frutos (Jones et al., 1991; Duarte et al., 2002). Essa espécie não possui nenhum vetor conhecido, porém possui uma partícula altamente estável, que facilita a transmissão mecânica. Além disso, o vírus é transmitido por sementes (Broadbent, 1976).

A maioria das cultivares de tomateiro comercializadas atualmente no Brasil possuem genes de resistência contra a infecção por ToMV. O gene de resistência identificado como $T m-2^{2}$ tem sido utilizado durante décadas para o controle desse tobamovirus (Hall, 1980). O mecanismo de controle utilizado por este gene está associado a restrição da movimentação do vírus na planta (Nishigushi \& Motoyoshi 1987). Entretanto, mesmo com a utilização de variedades de tomateiro com resistência, infecções esporádicas podem ocorrer em decorrência do surgimento de isolados ToMV capazes de superar a resistência conferida pelo gene $T m-2^{2}$ (Weber et al., 1993).

O gênero Potyvirus (família Potyviridae) é o segundo maior gênero de vírus de planta conhecido. Esses vírus são transmitidos mecanicamente, por sementes e por afídeos de forma não circulativa, pois os insetos são capazes de adquirir o vírus de uma planta infectada e transmitir para uma planta sadia apenas através de picadas de prova, de forma rápida e eficiente (Powell et al., 1995; Adams et al., 2011).

A risca do tomeiro tem como agente causal o potyvírus Potato virus $Y$ - PVY (Lima et al., 2015). Alguns isolados desse vírus causam apenas mosaico leve, outros induzem lesões necróticas nas folhas e estrias necróticas nas hastes, causando perdas no rendimento e na qualidade dos frutos (Legnani et al., 1995).

Além do PVY, o potyvírus Pepper yellow mosaic virus - PepYMV também infecta tomateiros no Brasil (Maciel-Zambolim et al., 2004). Esse vírus tem um grande potencial de dano à essa cultura e sua incidência tem aumentado nos últimos anos. Seus sintomas incluem clorose internerval, bolhosidade, mosqueado e mosaico (Inoue-Nagata, 2013). 
Algumas espécies virais afetam o tomateiro e são consideradas emergentes na cultura, porém não foram relatadas no Brasil. Por conta do potencial dano que causariam em caso de introdução, estão incluídas na lista de pragas quarentenárias ausentes do Ministério da Agricultura, Pecuária e Abastecimento (MAPA). Alguns desses vírus estão listados na Tabela 1.

Tabela 1: Vírus que infectam tomateiro e são considerados pragas quarentenárias ausentes para o Brasil.

\begin{tabular}{ll}
\multicolumn{1}{c}{ Espécie } & Gênero \\
\hline Pepino mosaic virus & Potexvirus \\
\hline Tomato black ring virus & Nepovirus \\
\hline Tobacco rattle virus & Tobravirus \\
\hline Tomato ringspot virus & Nepovirus \\
\hline Pelargonium zonate spot virus & Anulavirus \\
\hline & Fonte: Mapa.
\end{tabular}

\section{Vírus transmitidos por sementes}

A transmissão por sementes, também conhecida como transmissão vertical, foi demonstrada no início do século XIX através de pesquisas que apresentaram o potyvírus Bean common mosaic virus - BCMV sendo transmitido por aproximadamente $50 \%$ das sementes de feijoeiro (Reddick \& Steart, 1919).

A passagem dos vírus de plantas infectadas para seus descendentes através das sementes era um fenômeno considerado raro, hoje se sabe que isso ocorre em cerca de um sétimo dos vírus vegetais em pelo menos uma espécie por ele infectada (Hull, 2002; Albrechtsen, 2006; Sanches \& Krause-Sakate, 2013). Existe um alto grau de proteção dos embriões das sementes para evitar a invasão por vírus que infectem a planta-mãe, porém, alguns vírus são capazes de superar essa proteção e passar para a geração seguinte (Albrechtsen, 2006). 
A localização do vírus na semente define o tipo de transmissão por sementes (Lima et al., 2015). O tipo embrionário ocorre quando o vírus se aloja no interior do embrião da semente. A invasão do embrião pode ocorrer através dos grãos de pólen, do óvulo ou de invasão direta do embrião em algum estádio de desenvolvimento após a fecundação. A grande maioria dos vírus transmitidos por sementes pode invadir e sobreviver nos tecidos embrionários, onde ocorre uma intensa atividade metabólica (Johansen et al., 1994; Lima et al., 2015)

A transmissão não-embrionária ocorre quando a semente possui partículas virais aderidas à sua superfície e elas permanecem ativas até o momento da germinação, quando penetram o tecido da plântula durante os primeiros estádios de desenvolvimento (Johansen et al., 1994).

A porcentagem de transmissão por semente pode variar de acordo com a espécie e a estirpe do vírus, o genótipo do hospedeiro, a interação vírus-hospedeiro, a época de infecção da planta-mãe, a temperatura de produção e o tempo de armazenamento das sementes (Albrechtsen, 2006; Lima et al., 2015).

A característica mais importante nesse tipo de transmissão é a capacidade de disseminação a longa distância do(s) vírus associado(s), devido ao comércio de sementes em todo o mundo (Albrechtsen, 2006). A transmissão por sementes é um meio eficaz de introdução de vírus em um cultivo em fase inicial, pois se formam diversos focos de infecção primária em todo o plantio (Hull, 2002). O inóculo viral inicial associado a outras formas de transmissão horizontal eficientes levam a ocorrência de epidemia na lavoura (Albrechtsen, 2006).

Os danos econômicos diretos causados por vírus transmitidos por sementes incluem redução no rendimento e/ou na qualidade das colheitas, enquanto o dano indireto inclui os custos das medidas de controle. Um exemplo famoso é o caso do relato de perdas causadas 
por Barley stripe mosaic virus - BSMV nas plantações de cevada em Montana, nos Estados Unidos, estimadas em mais de 30 milhões de dólares entre os anos 1953 e 1970 (Carroll, 1983). Outro exemplo foi observado na Califórnia, onde os danos em plantações de alface foram causados por Lettuce mosaic virus - LMV na década de 1950 (Grogan, 1980). Ambos os casos foram resolvidos com a utilização de sementes livres ou quase livres de vírus (Albrechtsen, 2006).

A principal forma de manejo de vírus transmitidos por sementes é através da indexação de sementes (uso de sementes livres ou quase livres de vírus). A indexação normalmente implica em um maior controle fitossanitário, o que gera custos mais altos para a produção (Albrechtsen, 2006; Lima et al., 2015).

No Brasil, a preocupação com a entrada de patógenos por meio das sementes culminou na publicação da Instrução Normativa ${ }^{\circ}$ 06, em 16 de maio de 2005, que estabeleceu a prévia avaliação da veiculação de pragas dos materiais importados destinados à multiplicação ou propagação vegetal, por laboratórios de diagnóstico fitossanitário ou quarentena (MAPA, 2005; da Silva, 2013).

\section{O gênero Amalgavirus e o Southern tomato virus}

A família Amalgaviridae foi estabelecida em 2013, com o gênero Amalgavirus incluindo quatro espécies: Blueberry latent virus, Rhododendron virus A, Vicia cryptic virus M e Southern tomato virus (Tzanetakis \& Sabanadzovic, 2013). O compartilhamento de diversas propriedades e a história evolutiva em comum entre esses vírus justificaram o reconhecimento desses táxons como distintos dos demais vírus de RNA fita dupla (Tzanetakis \& Sabanadzovic, 2013).

Os novos membros da família Amalgaviridae compartilham propriedades com os totivirus, como o genoma monopartido, a organização bicistrônica e a RNA polimerase expressa como uma proteína de fusão, por meio do mecanismo de frameshifting ribossomal 
+1 (Sabanadzovic et al., 2009). A falta de qualquer sintoma ou efeito visível sobre os hospedeiros, a alta eficiência na transmissão vertical e a não transmissão através de enxertia são características compartilhadas com os partitivirus existentes (Sabanadzovic et al., 2009). Essas semelhanças sugerem que os amalgavírus podem representar uma ligação evolutiva entre essas duas famílias. Análises filogenéticas demonstram a maior proximidade dos amalgavírus com membros da família Partitiviridae do que com membros da família Totiviridae, apesar dos partitivírus terem seu genoma separado em mais de um segmento de RNA fita dupla (Sabanadzovic et al., 2009; Tzanetakis \& Sabanadzovic, 2013).

O Southern tomato virus (STV), espécie-tipo do gênero Amalgavirus, foi descrito em 2009 na América do Norte (isolados dos Estados Unidos e do México) com suspeitas de associação com uma nova desordem em tomate (Sabanadzovic et al., 2009). A sua detecção em mudas assintomáticas de algumas variedades deixou dúvidas sobre a sua patogenicidade. Não há evidências de transmissão mecânica ou por enxertia do STV, porém experimentos realizados com sementes coletadas de plantas infectadas com o vírus confirmaram elevadas taxas de transmissão vertical (70 - 90\%) (Sabanadzovic et al., 2009).

Segundo Sabanadzovic et al. (2009), seu genoma consiste em um RNA fita dupla (dsRNA) de aproximadamente 3,5 Kb, composto de duas fases de leitura abertas (ORFs) sobrepostas: a primeira inicia-se no nucleotídeo 138, estendendo-se até o nucleotídeo 1.271, e codifica uma proteína de revestimento (capa proteíca - CP) composta de 377 aminoácidos, com massa molecular de 42,4 kDa. A segunda ORF está localizada entre os nucleotídeos 1.039 e 3.325 e dá origem à uma RNA polimerase (RNA-dependent RNA polymerase RdRp) composta de 762 aminoácidos, com massa molecular de 87,4 kDa (Figura 2). Essa RdRp é expressa como uma proteína de fusão com massa molecular de 121,5 kDa. O heptanucleotídeo GGGAAGA, localizado entre os nucleotídeos 984 e 990, foi identificado 
como a sequência "deslizante" que facilita esse frameshifting ribossomal +1 (Sabanadzovic et al., 2009).

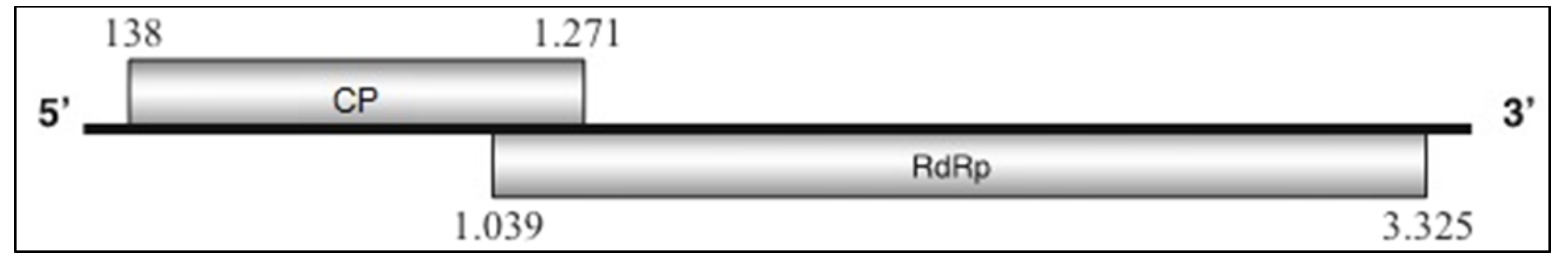

Figura 2: Representação esquemática do genoma de um amalgavírus que consiste de um RNA dupla fita (dsRNA) de aproximadamente $3,5 \mathrm{~Kb}$, com duas ORFs sobrepostas que codificam uma capa proteica (CP) com massa molecular de 42,4 kDa e uma RNA polimerase (RdRp) com massa molecular de 87,4 kDa (Adaptado de Sabanadzovic et al., 2010).

Candresse et al. (2013) relataram STV infectando tomateiros que apresentavam diversos sintomas de infecção viral como mosaico e deformação foliar, coletadas em 2011 no Sudoeste da França. Após análise por sequenciamento, a presença do vírus foi confirmada por RT-PCR e sequenciamento do fragmento obtido. Este foi o primeiro relato de STV infectando o tomateiro fora da América do Norte. As plantas a partir da qual foi recuperado o vírus apresentavam distintos sintomas típicos de infecção viral, tais como mosaico e deformação foliar, e também estavam infectadas com Tomato mosaic virus (ToMV) e Potato virus Y (PVY), o que impediu os autores de definirem a potencial contribuição do STV nos sintomas observados (Candresse et al., 2013).

O vírus foi relatado na Espanha após análise por NGS de tomateiros da cultivar Mariana, coletados em 2006, os quais também estavam infectados com Tomato torrado virus (ToTV) e Tomato chlorosis virus (ToCV). Uma nova amostragem feita em 2014 revelou a presença do STV em plantas da mesma cultivar, porém também em co-infecção com Pepino mosaic virus (PepMV), Tomato spotted wilt virus (TSWV) e Tomato yellow leaf curl virus (TYLCV) (Verbeek et al., 2015).

No verão de 2012, plantas de tomateiro com sintomas como mosaico forte, epinastia, enrolamento foliar e nanismo foram coletadas em estufas no leste da China, analisadas por 
sequenciamento de alto desempenho, sendo detectado o STV (Padmanabhan et al., 2015). Adicionalmente, Cucumber mosaic virus (CMV), Tomato yellow leaf curl virus (TYLCV) e Tomato chlorosis virus (ToCV) também foram detectados. O genoma obtido nessas análises compartilhava $99 \%$ de identidade de nucleotídeos com outros genomas depositados no GenBank, o que indica conservação da sequência entre os diferentes isolados de STV e possível compartilhamento de origem (Padmanabhan et al., 2015).

Ainda na Ásia, o STV foi detectado em Bangladesh após análise de plantas de um campo de produção de sementes (Padmanabhan et al., 2015b). Havia alta incidência de sintomas semelhantes aos de doenças virais, o que levou a realização de análises por sequenciamento de alto desempenho, detectando STV, PVY e CMV (Padmanabhan et al., $2015 b)$.

Iacono et al. (2015) analisaram 25 amostras de tomateiro na Itália, que apresentavam sintomas como clorose nas folhas e frutos, deformações e manchas escuras que posteriormente evoluiram para necrose nos frutos. Sete plantas apresentaram co-infecção com STV, PepMV e PVY. Os autores sugeriram a possibilidade de aumento da severidade dos sintomas em plantas co-infectadas com STV e PepMV em comparação a plantas infectadas apenas com PepMV.

Em todos os casos, o STV foi detectado em co-infecção com outros vírus, o que dificulta o estudo de sua sintomatologia e os efeitos de sua presença em lotes de sementes comerciais de diversas variedades. Outros fatores que complicam essas análises estão relacionados a não transmissão por enxertia ou inoculação mecânica, e a incapacidade de purificação de virions de tomateiros infectados (Sabanadzovic et al., 2009)

A ausência do vírus em amostras sintomáticas e mudas positivas sem sintomas causaram dúvidas a respeito de sua patogenicidade (Sabanadzovic et al., 2009). Sua alta taxa de transmissão vertical sugere que a sua distribuição pode ser mais ampla do que é atualmente 
conhecido. Tal distribuição mais ampla gerou preocupações para a indústria do tomate (Candresse et al., 2013).

Pesquisas adicionais e caracterização de suas propriedades biológicas e moleculares são necessárias para uma resposta final e conclusiva quanto ao seu potencial de patogenicidade (Iacono et al., 2015).

\section{Técnicas tradicionais utilizadas para detecção e identificação de vírus vegetais}

A diagnose de espécies virais pode ser realizada pela simples observação dos sintomas na planta infectada (Lima et al., 2015), mas a diferenciação de espécies com base na sintomatologia é difícil, incompleta e pouco confiável, devido a semelhança dos sintomas causados por diferentes vírus (Sanches \& Krause-Sakate, 2013).

A diagnose utilizando os diversos métodos disponíveis é o procedimento mais seguro, que leva a um diagnóstico correto e definitivo (Lima et al., 2015). Há diversos testes disponíveis para se detectar e identificar um vírus fitopatogênico, dentre testes biológicos, sorológicos e moleculares (Sanches \& Krause-Sakate, 2013).

Os testes biológicos incluem inoculação mecânica e a enxertia (Sanches \& KrauseSakate, 2013). A inoculação mecânica consiste em promover a liberação das partículas virais do interior da célula através da maceração do tecido da planta na presença de solução tampão e inoculá-las no interior das células de novas plantas indicadoras, friccionando o extrato contendo as partículas sobre a superfície das folhas (Lima et al., 2015). A enxertia é utilizada quando existem suspeitas de infecção por vírus não transmitidos mecanicamente. Sua realização envolve características peculiares a cada cultura (Sanches \& Krause-Sakate, 2013).

A sorologia é o método mais usado nos últimos 30 anos para identificação, caracterização e diagnose de vírus vegetais. O grande valor dos métodos sorológicos é a especificidade da reação entre antígeno (partícula viral ou proteína capsidial) e seu anticorpo específico (Lima et al., 2015). A principal técnica baseada em sorologia utilizada é o 
"enzyme- linked immunosorbent assay" - ELISA, que baseia-se na mudança de cor de um substrato incolor (normalmente $p$-nitrofenil fosfato) para uma coloração amarela a partir da ocorrência da reação específica entre antígeno e anticorpo (Lima et al., 2015). O ELISA e suas variações possuem alta adaptabilidade, sensibilidade, especificidade e praticidade (Lima et al., 2015; Sanches \& Krause-Sakate, 2013).

Os testes moleculares são considerados os mais específicos e precisos por se relacionarem com o genoma viral (Sanches \& Krause-Sakate, 2013). A Polymerase Chain Reaction - PCR foi desenvolvida no final dos anos 1980 e revolucionou a genética molecular. Essa técnica permite a amplificação de um fragmento de DNA limitado por dois oligonucleotídeos (primers) em progressão geométrica, utilizando a DNA polimerase (Erlich, 1989). Ela é utilizada para a detecção e identificação de vírus com genoma composto por DNA, para patógenos com genoma composto de RNA, antes da PCR deve-se realizar a etapa de transcrição reversa (RT), que sintetiza um DNA complementar (cDNA) a partir do RNA, utilizando a enzima transcriptase reversa (Sanches \& Krause-Sakate, 2013).

O resultado é obtido a partir da análise do produto de PCR por meio de gel de agarose, corado com um corante fluorescente intercalante. As bandas são comparadas com um marcador padrão de bandas previamente conhecido e a visualização de banda com o tamanho do fragmento amplificado pelos primers determina um resultado positivo (Sanches \& KrauseSakate, 2013).

A microscopia eletrônica é um método útil em casos de pouca ou nenhuma informação de ocorrência do vírus na cultura analisada ou quando um diagnóstico conclusivo não foi possível com a utilização de outros métodos mencionados. As duas técnicas mais utilizadas são o "leaf dip", simples, mas não detecta organismos restritos ao floema, e a técnica das seções ultrafinas, mais complexa e que demanda utilização de ultramicrótomo (Sanches \& Krause-Sakate, 2013). O "leaf dip" permite a visualização das partículas virais em alguns 
minutos, a partir do extrato da planta macerado em um corante (Lima et al., 2015). A técnica de seções ultrafinas exige reações que fixam, lavam, desidratam e polimerizam a amostra antes da realização dos cortes em ultramicrótomo, e a realização dessas preparações levam no mínimo sete dias (Sanches \& Krause-Sakate, 2013).

A microscopia eletrônica é uma técnica pouco utilizada para diagnose, pois microscópios eletrônicos são equipamentos caros e de difícil manutenção. Além disso, a especifidade da identificação chega ao nível de família ou gênero apenas (Sanches \& KrauseSakate, 2013).

Todas as técnicas utilizadas possuem algumas limitações, mas no geral, atendem perfeitamente à demanda em casos de diagnose de vírus já caracterizados.

\section{Sequenciamento de alto desempenho (Next generation sequencing - NGS)}

O sequenciamento de alto desempenho é um recente e marcante avanço na identificação e descoberta de vírus. Está rapidamente se tornando um método comum, utilizado principalmente para a obtenção de genomas completos de vírus de plantas em um período de tempo relativamente curto, ou de um enorme volume de informações sobre o genoma de forma rápida e precisa (Kehoe et al., 2014).

A diagnose de vírus fitopatogênicos é realizada através de técnicas biológicas, sorológicas e moleculares que funcionam perfeitamente para vírus conhecidos, porém, seu sucesso depende da existência de compostos específicos para o patógeno-alvo (Quan et al., 2008; Adams et al., 2009; Wu et al., 2015). Por exemplo, uma detecção por ELISA exige um antissoro específico para reagir com a proteína capsidial ou a partícula viral, assim como a detecção por PCR e/ou RT-PCR exige primers desenhados para a sequência do patógenoalvo.

A detecção e identificação de novo vírus exigia uma grande variedade de técnicas tradicionais e modernas. O processo iniciava-se por um rastreio de uma gama de vírus 
conhecidos e suspeitos, utilizando testes sorológicos como o ELISA, ou moleculares como reação em cadeia da polimerase (PCR). Posteriormente, caso os patógenos não sejam detectados, a microscopia eletrônica também é aplicada (Adams et al., 2009).

O problema significativo está no período de tempo necessário para a identificação do agente causador de uma nova doença, onde não se tem informações sobre sua morfologia, composição ou características químicas e físicas (Quan et al., 2008; Adams et al., 2009; Wu et al., 2015).

A necessidade de execução de múltiplos testes para a identificação precisa do patógeno demanda um período longo de análises, por exemplo, a identificação do Blackcurrant reversion virus foi possível após anos de pesquisa, utilizando métodos sorológicos e moleculares (Adams et al., 2009). Devido a essas dificuldades, virologistas procuraram novas abordagens para melhorar a identificação das causas de novas doenças. Uma abordagem promissora foi a da metagenômica. A metagenômica é o estudo de populações microbianas de uma amostra através da análise de sua sequência de nucleotídeos. A abordagem metagenômica para diagnose na virologia vegetal ofereceu a possibilidade de superação dos problemas com as técnicas de identificação tradicionais (Adams et al., 2009).

Os primeiros projetos metagenômicos utilizaram o sequenciamento feito com o método de Sanger e tinham custos bastante elevados. O método de Sanger automatizado gerou uma série de realizações importantes, mas as limitações desse método mostraram a necessidade do desenvolvimento de novas tecnologias para o sequenciamento de um grande número de genomas. Ao final do século XX, os esforços resultaram no lançamento de novo método conhecido como Next generation sequencing - NGS (Adams et al., 2009; Barba et al., 2014).

O sequenciamento de alto desempenho sequencia cada molécula em modo de elevado rendimento para a obtenção de sequências curtas de uma ou de ambas as extremidades. Antes do sequenciamento, uma população de RNA é convertida para uma biblioteca de cDNA, que 
posteriormente é segmentada e aditada para inclusão de adaptadores em ambas extremidades. Os reads gerados possuem tipicamente 30 a 400 nucleotídeos, a depender da tecnologia de sequenciamento utilizada. Após o sequenciamento, os reads resultantes são utilizados em análises de bioinformática para identificação e montagem de genomas (Wang et al., 2009).

Diversas plataformas que utilizam diferentes tecnologias para preparação da amostra, sequenciamento e obtenção de dados estão disponíveis comercialmente (Barzon et al., 2011). A combinação única de protocolos específicos distingue uma tecnologia da outra e determina o tipo de dados produzidos a partir de cada plataforma (Metzker et al., 2010).

Exemplos de plataformas disponíveis são a Roche/454, a Life/APG e a Illumina/Solexa. As plataformas Roche/454 e Life/APG utilizam a amplificação por PCR, realizada em emulsão contendo micro-esferas para o preparo das amostras. Para sequenciar, a plataforma Roche/454 utiliza o pirossequenciamento, e a plataforma Life/APG utiliza o sequenciamento por ligação (Metzker et al., 2010).

A plataforma Illumina domina o mercado de plataformas para sequenciamento de alto desempenho (Metzker et al., 2010). O processo realizado na plataforma Illumina/Solexa inicia-se com a fragmentação do DNA ou cDNA e a ligação de adaptadores às extremidades desses fragmentos (Lu et al., 2016). Essa plataforma utiliza a amplificação em fase sólida para a preparação das amostras, técnica que pode produzir 100 a 200 milhões de agrupamentos amplificados separadamente (Figura 3) (Metzker et al., 2010).

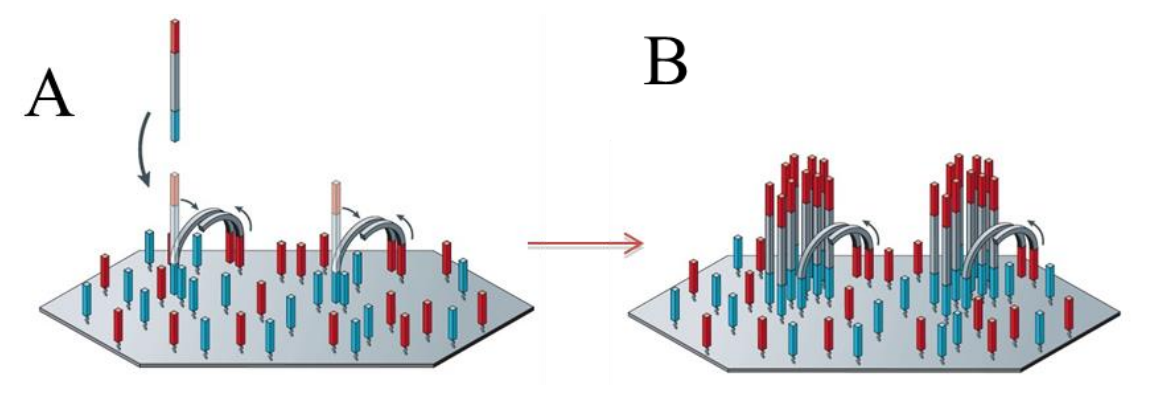

Figura 3: Representação esquemática do processo de imobilização e preparo de amostras. (A) Os fragmentos são ligados a uma superfície com primers complementares aos adaptadores, 
conhecida como flowcell; (B) múltiplas amplificações por PCR gerarão aglomerados de fragmentos conhecidos como clusters (Adaptado de Metzker et al., 2010).

O sequenciamento ocorre através da técnica conhecida como Cyclic reversible termination, que compreende a incorporação de um nucleotídeo fluorescente, a lavagem (retirada de nucleotídeos não incorporados), a obtenção de imagem de quatro cores (obtenção de dados) e a clivagem (remoção do corante florescente e do grupo de inibição) (Figura 4) (Metzker et al., 2010; Lu et al., 2016).
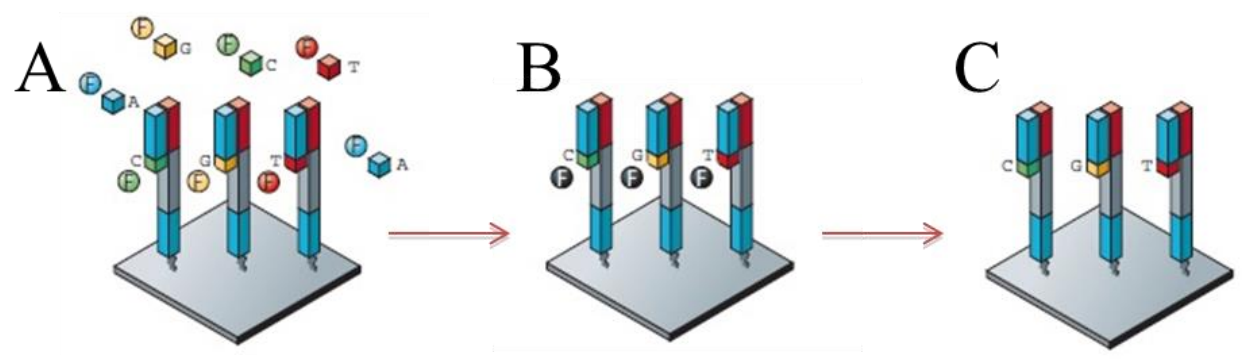

Figura 4: Representação esquemática do processo de sequenciamento utilizado na plataforma Illumina. (A) Um nucleotídeo marcado com fluorescência é incorporado; (B) ocorre a lavagem para a retirada dos nucleotídeos que não foram incorporados e a obtenção de imagem de quatro cores para captação da fluorescência; e (C) clivagem é realizada para retirada da fluorescência e do grupo de inibição (Adaptado de Metzker et al., 2010).

O advento do sequenciamento de alto desempenho transformou a realização de estudos metagenômicos de grande escala em procedimentos práticos e de baixo custo. Um exemplo disso foi o trabalho desenvolvido por Al Rwahnih et al. (2009), visando elucidar os vírus associados aos sintomas de declínio da videira cv. Syrah., analisando sequências obtidas do RNA total destas plantas por meio do sequenciamento de alto desempenho. Um total de 67,5 megabases de dados de sequência foram obtidos e analisados para a presença de sequências de origem viral. Constatou-se que os sintomas de declínio estavam associados à infecção mista de sete diferentes RNAs virais. Do total de fragmentos sequenciados, 1.527 foram derivados de um marafivirus desconhecido, cujo genoma completo foi sequenciado e caracterizado. RT-PCR foi desenvolvido para analisar a distribuição do novo vírus 
(Grapevine Syrah virus 1, GSyV-1) e assim demonstrou-se sua presença em cigarrinhas vetoras (Al Rwahnih et al., 2009).

Em trabalho semelhante, Wylie et al. (2012) conduziram sequenciamento de alto desempenho usando a Plataforma Illumina GAIIx a partir de RNAs poliadenilados extraídos de 120 amostras de 17 espécies de plantas, reunidos e sequenciados em conjunto. Após a análise, sequências genômicas completas ou parciais de 20 isolados distribuídos em 16 espécies virais foram determinadas. Doze dos vírus identificados foram previamente descritos e pertenciam aos gêneros Potyvirus, Nepovirus, Allexivirus e Carlavirus. Quatro eram desconhecidos e foram propostos como membros dos gêneros Potyvirus, Sadwavirus e Trichovirus, sendo que as sequências virais obtidas também foram detectadas nas hospedeiras originais por meio de RT-PCR. Já Poojari et al. (2013) identificaram uma nova linhagem evolucionária de um vírus da família Geminiviridae, que infecta videiras, também utilizando sequenciamento de alto desempenho.

Diversos relatos da ocorrência de sintomas típicos de infecções virais em plantas forrageiras em áreas experimentais da Embrapa Gado de Corte e da Embrapa Gado de Leite e o pouco conhecimento de infecções virais em plantas forrageiras no Brasil motivaram da Silva (2015) a realizar análise por NGS em gramíneas forrageiras com o objetivo de identificar o agente etiológico de sérias doenças ainda não caracterizadas. Johnsongrass mosaic virus - JGMV, um potyvírus, foi relatado infectando espécies de Pennisetum, Brachiaria e Panicum. Dois isolados do vírus foram caracterizados e o trabalho demonstrou a presença de alta diversidade genética de JGMV em plantas forrageiras, que está associada à estreita base genética das forrageiras, dificultando a obtenção de resistência a vírus em programas de melhoramento genético.

Dos Santos (2016) utilizou o sequenciamento de alto desempenho para identificar e caracterizar espécies virais em espécies arbóreas nativas de diversos biomas encontrados no 
Brasil. Uma sequência genômica com 9.529 nucleotídeos foi analisada e sugerida como genoma de novo membro da ordem Picornavirales, denominado Hovenia dulcis associated virus (HDAV).

Os aperfeiçoamentos das tecnologias utilizadas no sequenciamento de alto desempenho atraem cada vez mais pesquisadores da área de virologia vegetal. Os trabalhos mostram como é possível a ampliação do conhecimento acerca da população viral de qualquer cultura de interesse. 


\section{LITERATURA CITADA}

ADAMS, I.P.; GLOVER, R.H.; MONGER, W.A.; MUMFORD, R.; JACKEVICIENE,E.; NAVALINSKIENE, M.; SAMUITIENE, M. \& BOONHAM, N. 2009. Next generation sequencing and metagenomic analysis: a universal diagnostic tool in plant virology. Molecular Plant Pathology 10: 537-545.

ADAMS, M.J.; ZERBINI, F.M.; FRENCH, R.; RABENSTEIN, F.; STENGER, D.C. \& VALKONEN, J.P.T. 2011. Genus Potyvirus. In: KING, A.; LEFKOWITZ, E.; ADAMS, M. J.; CARSTENS, E. B. Virus Taxonomy: Ninth Report of the International Committee on Taxonomy of Viruses. Elsevier Academic Press, San Diego, Califórnia. p. 1072-1078.

AL RWAHNIH, M.; DAUBERT. S.; GOLINO, D. \& ROWHANI, A. 2009. Deep sequencing analysis of RNAs from a grapevine show ing Syrah decline symptoms reveals a multiple virus infection that includes a novel virus. Virology 387: 395-401.

ALBRECHTSEN, S. E. 2006. Testing methods for seed-transmitted viruses: principles and protocols. CABI International. Cambridge, Estados Unidos da América.

ALBUQUERQUE, L.C.; VARSANI, A.; FERNANDES, F.R.; PINHEIRO, B.; MARTIN, D.P.; FERREIRA, P.T.O; LEMOS, T.O. \& INOUE-NAGATA, A.K. 2012. Further characterization of tomato-infecting begomoviruses in Brazil. Archives of Virology 157: 747-52.

ALVARENGA, M.A.R. \& COELHO, F.B. 2013. Valor nutricional. In: ALVARENGA, M.A.R. Tomate: produção em campo, casa de vegetação e hidroponia. $2^{\mathrm{a}}$ ed. Universidade de Lavras. Lavras. p. 23-29.

ALVARENGA, M.A.R. 2013. Origem, botânica e descrição da planta. In: ALVARENGA, M.A.R. Tomate: produção em campo, casa de vegetação e hidroponia. $2^{\mathrm{a}}$ ed. Universidade de Lavras. Lavras. p. 11-21.

ALVARENGA, M.A.R.; DE MELO, P.C.T. \& SHIRAHIGE, F.H. 2013b. Cultivares. In: ALVARENGA, M.A.R. Tomate: produção em campo, casa de vegetação e hidroponia. $2^{a}$ ed. Universidade de Lavras. Lavras. p. 39-62.

ARAMBURU, J.; GALIPIENSO, L.; SOLER, S. \& LÓPEZ, C. 2010. Characterization of Tomato spotted wilt virus isolates that overcome the $\mathrm{Sw}-5$ resistance gene in tomato and fitness assays. Phytopathology 49: 342-351.

ARRUABARRENA, A, RUBIO, L.; GONZÁLEZ-ARCOS, M.; MAESO, D.; SÁNCHEZCAMPOS, FONSECA M. E.N. \& BOITEUX L. S. 2015. First Report of Solanum sisymbriifolium and S. americanum as natural weed hosts of Tomato chlorosis virus (Genus Crinivirus) in South America. Plant disease 99 (6): 895. 
ARRUABARRENA, A.; RUBIO, L.; GONZÁlEZ-ARCOS, M.; MAESO, D.; SÁNCHEZCAMPOS, S.; FONSECA, M.E.N. \& BOITEUX, L.S. 2015. First report of Solanum sisymbriifolium and S. americanum as natural weed hosts of Tomato chlorosis virus (Genus Crinivirus) in South America. Plant Disease 99(6): 895.

BARBA, M.; CZOSNEK, H. \& HADIDI, A. 2014. Historical perspective, development and applications of next generation sequencing in plant virology. Viruses 6: 106-136.

BARBOSA, J.C.; COSTA, H.; GIORIA, R. \& REZENDE, J.A.M. 2011. Occurrence of Tomato chlorosis virus in tomato crops in five Brazilian states. Tropical Plant Pathology 36(4): 256-258.

BARBOSA, J.C.; HÉlCIO COSTA, H.; GIORIA, R. \&. REZENDE J.A.M. 2011. Occurrence of Tomato chlorosis virus in tomato crops in five Brazilian states. Tropical Plant Pathology 36 (4): 256-258.

BARBOSA, J.C.; TEIXEIRA, A.P.M.; MOREIRA, A.G.; CAMARGO, L.E.A.; FILHO, A.B.; KITAJIMA, E.W. \& REZENDE, J.A.M. 2008. First Report of Tomato chlorosis virus Infecting Tomato Crops in Brazil. Plant Disease 92: 1709-1709.

BARBOZA, E.A. 2014. Ocorrência e diversidade de Pythium e Phytophthora em fontes de água utilizada para irrigação na Região do Distrito Federal. Dissertação de Mestrado. Universidade de Brasília, Brasília, Brasil.

BARZON, L.; LAVEZZO, E.; MILITELLO, V.; TOPPO, S. \& PALÙ, G. 2011. Applications of next generation sequencing technologies to diagnostic virology. International Journal of Molecular Science 12: 7861-7884.

BEZERRA, I.C. DE O; RESENDE, R.; POZZER, L.; NAGATA, T.; KORMELINK, R. \& DE ÁVILA, A.C. 1999. Increase of tospoviral diversity in Brazil with the identification of two new tospovirus species, one from chrysanthemum and one from zucchini. Phytopathology 89(9): 823-830.

BLAIR, H. \& MACNEILL.1950. Studies in Septoria Lycopersici speg. Canadian Jounal of Research 28: 645-672.

BROADBENT, L. 1976. Epidemiology and control of tomato mosaic virus.Annual review of Phytopathology 14(1): 75-96.

BUENO, C.J.; AMBRÓSIO, M.M. DE Q. \& SOUZA, N.L. 2007. Produção e avaliação da sobrevivência de estruturas de resistência de fungos fitopatogênicos habitantes do solo. Summa Phytopathologica 33(1): 47-55.

CANDRESSE, T.; MARAIS, A. \& FAURE, C. 2013. First report of Southern tomato virus on tomatoes in Southwest France. Plant Disease 97, 1124. 
CARROLL, T.W. 1983. Certification schemes against barley stripe mosaic. Seed Science and Technology 11: 1033-1042.

CARVALHO, J.L. \& PAGLIUCA, L.G. 2007. Tomate - um mercado que não pára de crescer. Hortifruti Brasil 58: 6-14.

DA GRAÇA, A.J.P. 2013. Heterose e capacidade combinatória de linhagens de tomateiro (Solanum lycopersicum L.) prospectadas para dupla finalidade. Dissertação de Mestrado. Universidade Estadual do Norte Fluminense Darcy Ribeiro, Rio de Janeiro, Brasil.

DA SILVA, A.F.C.P. 2013. A fiscalização do comércio de sementes e mudas como ferramenta de prevenção e controle de pragas dos vegetais. Dissertação de Mestrado. Universidade Federal de Viçosa. Minas Gerais, Brasil.

DA SILVA, K.N. 2015. Caracterização molecular de Johnsongrass mosaic virus em plantas forrageiras dos gêneros Brachiaria, Panicum e Pennisetum. Dissertação de Mestrado. Universidade de Brasília. Brasília, Brasil.

DILDEY, O.D.F.; BARBIAN, J.M.; GONÇALVES, E.D.V.; BROETTO, L.; ETHUR, L.Z.; KUHN, O.J. \& BONETT, L.P. 2014. Inibição do crescimento in vitro de Sclerotinia sclerotiorum, causador de mofo branco, por isolados de Trichoderma spp. Revista Brasileira de Biociências 12(3): 132-136.

DO VALE, F.X.R.; LOPES, C.A. \& ALVARENGA, M.A.R. 2013. Doenças fúngicas, bacterianas e causadas por nematoides. In: ALVARENGA, M.A.R. Tomate: produção em campo, casa de vegetação e hidroponia. $2^{\mathrm{a}}$ ed. Universidade de Lavras. Lavras. p. 275-277.

DOS SANTOS, F.M.B. 2016. Análise do viroma em espécies arbóreas. Dissertação de Mestrado. Universidade de Brasília. Brasília, Brasil.

DUARTE, K.M.R.; GOMES, L.H.; ANDRINO, F.G.; LEAL JR, G.A.; SILVA, F.H.B.; PASCHOAL, J.A.R.; GIACOMELLI, A.M.B. \& TAVARES, F.C.A. 2002. Identificação do vírus do mosaico do tomateiro (ToMV) Tobamovirus, por meio de anticorpos monoclonais. Scientia Agrícola 59: 107-112.

ERLICH, H.A. 1989. Polymerase chain reaction. Journal of clinical immunology 9(6): 437447.

FAOSTAT. 2016. Database results. FAO. http://faostat3.fao.org/home/E. Acesso em 4 de agosto de 2016.

FERNANDES, F.R.; ALBUQUERQUE, L.C.; GIORDANO, L.B.; BOITEUX, L.S.; DE ÁVILA, A.C. \& INOUE-NAGATA, A.K. 2008. Diversity and prevalence of Brazilian 
bipartite begomovirus species associated to tomatoes. Virus Genes 36: 251-258.

FONSECA, M.E.N. ; BOITEUX, L.S. ; ABREU, N.H. \& PEREIRA-CARVALHO, R.C. 2013. Physalis angulata: a new natural host of Tomato chlorosis virus in Brazil. Plant disease (Disease Notes) 97 (5): 1027.

FORTES, I. M. \& NAVAS-CASTILLO, J. 2012. Potato, an experimental and natural host of the crinivirus Tomato chlorosis virus. European journal of plant pathology 134(1): 8186.

GARCÍA-CANO, E.; NAVAS-CASTILLO, J.; MORIONES, E. \& FERNÁNDEZ-MUÑOZ, R. 2010. Resistance to Tomato chlorosis virus in wild tomato species that impair virus accumulation and disease symptom expression. Phytopathology 100: 582-592.

GARCÍA-CANO, E.; RESENDE, R.O.; FERNANDEZ-MUÑOS, R. \& MORIONES, E. 2006. Synergistic interaction between Tomato chlorosis virus and Tomato spotted wilt virus results in breakdown of Resistance in tomato. Phytopathology 96: 1263-1269.

GHANIM, M. 2014. A review of the mechanisms and components that determine the transmission efficiency of Tomato yellow leaf curl virus (Geminiviridae; Begomovirus) by its whitefly vector. Virus Research 186: 47-54.

GROGAN, R.G. 1980. Control of lettuce mosaic with virus-free seed. Plant Disease 64: 446449.

HALL, T.J. 1980. Resistance at the Tm-2 locus in the tomato to Tomato mosaic virus. Euphytica 29:189-197.

HULL, R. 2002. Plant Virology. $4^{\mathrm{a}}$ edição. Academic Press. Estados Unidos da América.

IACONO, G; HERNANDEZ-LLOPIS, D.; ALFARO-FERNANDEZ, A.; DAVINO, M.; FONT, M.I.; PANNO, S.; GALIPIENSO, L.; RUBIO, L. \& DAVINO, S. 2015. First report of Southern tomato virus in tomato crops in Italy. New disease reports 32: 27.

IBGE. 2016. Levantamento sistemático da produção agrícola: pesquisa mensal de previsão e acompanhamento das safras agrícolas no ano civil. IBGE. ftp://ftp.ibge.gov.br/Producao_Agricola/Levantamento_Sistematico_da_Producao_Agric ola_\%5Bmensal\%5D/Fasciculo/lspa_201601.pdf. Acesso em 29 de julho de 2016.

INOUE-NAGATA, A.K. 2013. Doenças viróticas. In: ALVARENGA, M.A.R. Tomate: produção em campo, casa de vegetação e hidroponia. $2^{\mathrm{a}}$ ed. Universidade de Lavras. Lavras. p. 327-344.

JONES, J.B.; BOUZAR, H.; STALL, R.E.; ALMIRA, E.C.; ROBERTS, P.D.; BOWEN, B.W.; SUDBERRY, J.; STRICKLER, P.M. \& CHUN, J. 2000. Systematic analysis of xanthomonads (Xanthomonas ssp.) associated with pepper and tomato lesions. 
International Journal of Systematic Bacteriology 50:1211-1219.

JONES, J.B.; JONES, J.P.; STALL, R.E. \& ZITTER, T.A. 1991. Compendium of tomato diseases. American Phytopathological Society. Estados Unidos da América.

JONES, J.B.; LACY, G.H.; BOUZAR, H.; STALL, R.E. \& SCHAAD, N.W. 2004. Reclassification of the xanthomonads associated with bacterial spot disease of tomato and pepper. Systematic and Applied Microbiology 27: 755-762.

KEHOE, M.A.; COUTTS, B.A.; BUIRCHELL, B.J. \& JONES, R.A.C. 2014. Plant Virology and Next generation sequencing: Experiences with a Potyvirus. PLoS ONE 9: e104580.

KIMATI, H.; BERGAMIN FILHO, A.; AMORIM, L. 2011. Controle de doenças. In: AMORIM, L.; REZENDE, J.A.M. \& BERGAMIN FILHO, A. Manual de Fitopatologia: princípios e conceitos. $4^{\mathrm{a}}$ edição. Agronômica Ceres. São Paulo, SP. p. 306-323.

KUROZAWA, C. \& PAVAN, M.A. 2005. Doenças do tomateiro. In: KIMATI, H.; AMORIM, L.; REZENDE, J.A.M.; FILHO, A.B. \& CAMARGO, L.E.A. Manual de fitopatologia: doenças das plantas cultivadas. $4^{\mathrm{a}}$ ed. Agronômica Ceres. Piracicaba. p. 642-670.

LEGNANI, R.; SELASSIE, K.G.; WOMDIM, R.N.; GOGNALONS, P.; MORETTI, A.; LATERROT, H. \& MARCHOUX, G. 1995. Evaluation and inheritance of the Lycopersicon hirsutum resistance against Potato virus Y. Euphytica 86(3): 219-226.

LIMA, J.A.A.; NASCIMENTO, A.K.Q.; BARBOSA, G.S.; MAIA, L.M.; GOLÇALVES, M. F.B. \& DA SILVA, F.R. 2015. Virologia essencial e viroses em culturas tropicais. Edições UFC. Fortaleza, Ceará.

LOPES, C.A. \& REIS, A. 2011. Doenças do tomateiro cultivado em ambiente protegido. Corcórdia: Embrapa Hortaliças, Brasília - DF, 17 p. (Circular técnica, 100).

LOURENÇÃO, A.L.; ALVES, A.C.; FUGI, C.G.Q. \& MATOS, E.V.S. 2008. Outbreaks of Trialeurodes vaporariorum (West.) (Hemiptera:Aleyrodidae) under field conditions in the state of São Paulo, Brazil. Neotropical Entomology 37(1): 089-091.

LU, Y.; SHEN, Y.; WARREN, W. \& WALTER, R. 2016. Next generation sequencing in aquatic models. In: KULSKI, J.K. Next generation sequencing - advances, applications and challenges. InTech. p. 61-79.

MACIEL-ZAMBOLIM, E.; COSTA, H.; CAPUCHO, A.S.; ÁVILA, A.D.; INOUENAGATA, A.K. \& KITAJIMA, E.W. 2004. Surto epidemiológico do vírus do mosaico amarelo do pimentão em tomateiro na região serrana do Espírito Santo. Fitopatologia Brasileira 29(3): 325-327. 
MAPA. 2005. Instrução Normativa $n^{0}$ 06, de 16 de maio de 2005. BRASIL. http://sistemasweb.agricultura.gov.br/sislegis/action/detalhaAto.do?method=visualizarA toPortalMapa\&chave $=1123856005$. Acesso em 5 de agosto de 2016.

MELGAREJO, T.A.; KON, T.; ROJAS, M.R.; PAZ-CARRASCO, L.; ZERBINI, F.M. \& GILBERTSON, R.L. 2013. Characterization of a New World Monopartite Begomovirus Causing Leaf Curl Disease of Tomato in Ecuador and Peru Reveals a New Direction in Geminivirus Evolution. Journal of Virology. 87(10): 5397-5413.

METZKER, M.L. 2010. Sequencing technologies - the next generation. Nature Reviews Genetics 11: 31-46.

NAGATA, T.; ALMEIDA, A.C.L.; RESENDE, R.D.O. \& DE ÁVILA, A.C. 2004. The competence of four thrips species to transmit and replicate four tospoviruses. Plant Pathology 53(2): 136-140.

NAGATA, T.; RESENDE, R.D.O; KITAJIMA, E.W.; COSTA, H.; INOUE-NAGATA, A. K. \& DE ÁVILA, A.C. 1998. First report of natural occurrence of Zucchini lethal chlorosis tospovirus on cucumber and Chrysanthemum stem necrosis tospovirus on tomato in Brazil. Plant Disease 82(12): 1403-1403.

NASCIMENTO, A.R.; FERNANDES, P.M.; BORGES, L.C.; MOITA, A.W. \& QUEZADODUVAL, A.M. 2013. Controle químico da mancha-bacteriana do tomate para processamento industrial em campo. Horticultura Brasileira 31: 15-24.

NISHIGUSHI, F. \& MOTOYOSHI, F. 1987. Resistance mechanisms of Tobacco mosaic virus strains in tomato and tobacco. In: Plant resistance to viruses. EVERED, D.; S. HARNETT, S.; WILEY, J. \& SONS. Ciba Foundation. Inglaterra. p. 38-44.

NOGUEIRA, D.G.; MALUF, W.R.; NOGUEIRA, D.W.; MASCARENHAS, G.; VILELA, L. \& DOS REIS, A. 2011. Marcador microssatélite associado ao alelo Ty-1 de resistência a Begomovirus em tomateiro. Pesquisa Agropecuária Brasileira 46(4): 412-419.

PADMANABHAN, C.; ZHENG, Y.; LI, R.; FEI, Z. \& LING, K. 2015b. Complete genome sequence of Southern tomato virus naturally infecting tomatoes in Bangladesh. Genome Announcements 3(6): e01522-15.

PADMANABHAN, C.; ZHENG, Y.; LI, R.; SUN, S.; ZHANG, D.; LIU, Y.; FEI, Z. \& LING, K. 2015. Complete genome sequence of Southern tomato virus identified in China using next generation sequencing. Genome Announcements 3(5): e01226-15.

PAKKIANATHAN, B.C.; KONTSEDALOV, S.; LEBEDEV, G.; MAHADAV, A.; ZEIDAN, M.; CZOSNEK, H. \& GHANIM, M. 2015. Replication of Tomato yellow leaf curl virus in Its whitefly vector, Bemisia tabaci. Journal of virology 89(19): 9791-9803. 
PEREIRA, R.B.; CARVALHO, A. \& PINHEIRO, J. 2013. Recomendações para o manejo da septoriose em tomateiro. Concórdia: Embrapa Hortaliças, Brasília - DF, 4 p. (Comunicado técnico, 96).

PINHEIRO, J.B.; PEREIRA, R.B. \& SUINAGA, F.A. 2014. Manejo de nematoides na cultura do tomate. Concórdia: Embrapa Hortaliças, Brasília - DF, 12 p. (Circular técnica, 132).

POOJARI, S.; ALABI, O.J.; FOFANOV, V.Y. \& NAIDU, R.A. 2013. A leafhoppertransmissible DNA virus with novel evolutionary lineage in the family Geminiviridae implicated in Grapevine Redleaf Disease by next generation sequencing. PLoS ONE 8(6): e64194.

POWELL, G.; PIRONE, T. \& HARDIE, J. 1995. Aphid stylet activities during potyvirus acquisition from plants and anin vitro system that correlate with subsequent transmission. European journal of Plant pathology 101(4): 411-420.

QUAN, P.L.; BRIESE, T.; PALACIOS, G. \& LIPKIN, W.I. 2008. Rapid sequence-based diagnosis of viral infection. Antiviral research 79(1): 1-5.

QUEZADO-DUVAL A.M.; INOUE-NAGATA, A.K.; REIS, A.; PINHEIRO, J.B.; LOPES, C.A.; ARAÚJO, E.R.; FONTENELLE, M.R.; COSTA, J.R.; GUIMARÃES, C.M.N.; ROSSATO, M.; BECKER, W.F.; COSTA, H.; FERREIRA, M.A.S.V. \& DESTÉFANO, S.A.L. 2013. Levantamento de doenças e mosca-branca em tomateiro em regiões produtoras no Brasil. Concórdia: Embrapa Hortaliças, Brasília - DF, 36 p. (Boletim de Pesquisa e Desenvolvimento, 100).

QUEZADO-DUVAL, A.M. \& LOPES, C.A. 2010. Mancha bacteriana: uma atualização para o Sistema de Produção Integrada de Tomate Indústria. Concórdia: Embrapa Hortaliças, Brasília-DF, 24 p. (Circular técnica, 84).

REDDICK, D \& STEART, V.B. 1919. Transmission of virus of bean mosaic in seed and observation on thermal death-point of seed and virus. Phytopathology 9: 445-450.

REETZ, E.R.; KIST, B.B.; DOS SANTOS, C.E.; CARVALHO, C \& DRUM, M. 2014. Anuário brasileiro de hortaliças 2014. Editora Gazeta. http://www.grupogaz.com.br/tratadas/eo_edicao/6/2014/05/20140528_997424315/pdf/4 393_hortalicas_2014.pdf. Acesso em 29 de abril de 2015.

REIS, A. 2010. Requeima: doença destrutiva e comum ao tomateiro e à batateira. Concórdia: Embrapa Hortaliças, Brasília -DF, 7 p. (Comunicado técnico, 78).

REIS, A.; BOITEUX, L.S.; GIORDANO, L.B.; COSTA, H. \& LOPES, C.A. 2004. Ocorrência de Fusarium oxysporum f. sp. lycopersici raça 3 em tomate no Brasil e 
seleção de novas fontes de resistência ao patógeno. Concórdia: Embrapa Hortaliças, Brasília -DF, 36 p. (Boletim de Pesquisa e Desenvolvimento, 02).

RESENDE， R.D.O.; POZZER， L.; NAGATA， T.; BEZERRA， I.C.; LIMA， M.I.; GIORDANO, L.B.; KITAJIMA, E.W. \& DE ÁVILA, A.C. 1995. New tospoviruses found in Brazil. Tospoviruses and Thrips of Floral and Vegetable Crops 431: 78-89.

RODRIGUES, T.T. M. S.; BERBEE, M.L.; SIMMONS, E.G.; CARDOSO, C.R.; REIS, A; MAFFIA, L.A. \& MIZUBUTI, E.S.G. 2010. First report of Alternaria tomatophila and A. grandis causing early blight on tomato and potato in Brazil. New Disease Reports 22: 28.

SABANADZOVIC, S.; GHANEM-SABANADZOVIC, N.A. \& VALVERDE, R.A. 2010. A novel monopartite dsRNA virus from rhododendron. Archives of virology 155(11): 1859-1863.

SABANADZOVIC, S.; VALVERDE, R.A.; BROWN, J.K.; MARTIN, R.R.; TZANETAKIS, I.E. 2009. Southern tomato virus: the link between the families Totiviridae and Partitiviridae. Virus Research 140: 130-137.

SANCHES, M.M. \& KRAUSE-SAKATE, R. 2013. Análises para vírus, viroides e fitoplasmas em material vegetal importado. Concórdia: Embrapa Recursos Genéticos e Biotecnologia, Brasília - DF, 31 p. (Documentos, 344).

SOUZA, J.O. 2014. Análise da diversidade de begomovírus em tomateiros (Solanum lycopersicum) da região nordeste do brasil. Dissertação de Mestrado. Universidade de Brasília, Brasília, Brasil.

STANLEY, J.; BISARO, D.M.; BRIDDON, R.W.; BROWN, J.K.; FAUQUET, C.M.; HARRISON, B.D.; RYBICKI, E.P. \& STENGER, D.C. 2005. Family Geminiviridae. In: FAUQUET, C. M.; MAYO, A.; MANILOFF, J.; DESSELBERGER, U.; BALL, L. A. Virus Taxonomy: VIIIth Report of the International Committee on Taxonomy of Viruses. Elsevier/Academic Press. London. p. 789-792.

STEVENS, M.R.; SCOTT, S.J. \& GERGERICH, R.C. 1991. Inheritance of a gene for resistance to Tomato spotted wilt virus (TSWV) from Lycopersicon peruvianum Mill. Euphytica 59(1), 9-17.

SUASSUNA, N.D.; MAFFIA, L.A. \& MIZUBUTI, E.S.G. 2004. Aggressiveness and host specificity of Brazilian isolates of Phytophthora infestans. Plant Pathology 53(4): 405413.

TZANETAKIS, I.E. \& SABANADZOVIC, S. 2013. Establishment of the family Amalgaviridae, the genus Amalgavirus and inclusion of four species in the genus. 
ICTV. http://www.ictvonline.org/proposals/2013.005a-gP.A.v2.Amalgaviridae.pdf. Acesso em 25 de junho de 2016.

VERBEEK, M.; DULLEMANS, A.M.; ESPINO, A.; BOTELLA, M.; ALFAROFERNÁNDEZ, A. \& FONT, M.I. 2015. First report of Southern tomato virus in tomato in the Canary Islands, Spain. J Plant Pathol 97:392.

WANG, Z.; GERSTEIN, M. \& SNYDER, M. 2009. RNA-Seq: A revolutionary tool for transcriptomics. Nature Reviews Genetics 10: 57-63, 2009.

WEBER, H.; SCHULTZE, S. \& PFITZNER, A.J.P.1993. Two amino acid substitutions in the Tomato mosaic virus 30-kilodalton movement protein confer the ability to overcome the $\mathrm{Tm}-2^{2}$ resistance gene in the tomato. Journal of Virology 67(11): 6432-6438.

WIJKAMP, I.; ALMARZA, N.; GOLDBACH, R. \& PETERS, D. 1995. Distinct levels of specificity in thrips transmission of tospoviruses. Phytopathology 85(10): 1069-1074.

WINTERMANTEL, W.M. \& WISLER, G.C. 2006. Vector specificity, host range and genetic diversity of Tomato chlorosis virus. Plant Disease 90: 814-819.

WISLER, G. C.; DUFFUS, J. E.; LIU, H. Y. \& LI, R. H. 1998b. Ecology and epidemiology of whitefly-transmitted closteroviruses. Plant Disease 82(3): 270-280.

WISLER, G.C.; DUFFUS, J.E.; LIU, H.Y. \& LI, R.H. 1998. Ecology and epidemiology of whitefly-transmitted closteroviruses. Plant Disease 82 (3): 270-280.

WISLER, G.C.; LI, R.H.; LIU, H-Y. \& LOWRY, D.S. 1998. Tomato chlorosis virus: a new whitefly-transmitted, phloem-limited, bipartite closterovirus of tomato. Phytopathology 88: 402-409.

WU, Q.; DING, S.; ZHANG, Y \& ZHU, S. 2015. Identification of viruses and viroids by next generation sequencing and homology-dependent and homology-independent algorithms. Annual Review of Phytopathology 53: 425-444.

WYLIE, S.J.; LUO, H.; LI, H. \& JONES, M.G.K. 2012. Multiple polyadenylated RNA viruses detected in pooled cultivated and wild plant samples. Archives of Virology 157: 271-284. 


\section{CAPÍTULO 2}

Análise do viroma de tomateiro por sequenciamento de alto desempenho

\section{RESUMO}

O tomateiro é uma solanácea de importância mundial devido ao seu fruto, que possui compostos com propriedades antioxidantes e anticancerígenas. Em 2015, a produção brasileira ultrapassou três milhões de toneladas, com os estados de Goiás, Minas Gerais e São Paulo como maiores produtores. Essa cultura, no entanto, é alvo de diversos patógenos que podem prejudicar a produção. As viroses estão dentre as doenças de maior importância, pois os vírus estão amplamente disseminados nos campos de produção e são de difícil controle. A diagnose de vírus fitopatogênicos consiste na utilização de técnicas direcionadas a patógenos conhecidos ou variantes próximas, o que dificulta a detecção de vírus desconhecidos. A identificação de espécies virais não descritas normalmente requer a aplicação de uma grande variedade de técnicas tradicionais e modernas. Isso tornava o processo lento, demorado e difícil. Entretanto, o aperfeiçoamento de técnicas de sequenciamento em larga escala permitiu o lançamento de uma nova plataforma de sequenciamento conhecida como next generation sequencing-NGS, traduzido neste documento como sequenciamento de alto desempenho. $\mathrm{O}$ sequenciamento de alto desempenho sequencia massalmente toda a população de ácidos nucléicos contidos em uma amostra gerando sequências curtas conhecidas como reads, que são utilizados em análises de bioinformática para identificação e montagem de sequências de patógenos. Neste trabalho, cinco amostras compostas denominadas como BRAZ (BrazlândiaDF), AHOL, TOCA1 e TOCA2 (Campinas-SP) e CAM-RNY2 (Araguari-MG) foram submetidas ao processo de semi-purificação de partículas virais e extração de RNA, e implementou-se a técnica de sequenciamento de alto desempenho para detectar e identificar patógenos virais presentes em amostras de tomateiro e obter genomas virais completos ou parciais utilizando ferramentas da bioinformática. Diversos vírus de ocorrência comum nos campos de produção de tomate no Brasil foram detectados nas bibliotecas, como aqueles dos gêneros: Tospovirus, Begomovirus, Tymovirus, Crinivirus, Tobravirus, Potexvirus e Amalgavirus. Adicionalmente, a detecção e a montagem de dois genomas parciais de Southern tomato virus, um vírus ainda não relatado no Brasil, foi realizada utilizando ferramentas de bioinformática. Os genomas obtidos, STV-DF e STV-MG, cobriram respectivamente 3.418 e 3.415 nucleotídeos de um genoma total com 3.437 nucleotídeos (acesso NC_011591). O sequenciamento de alto desempenho constitui-se em uma ferramenta 
útil para detecção de vírus conhecidos ou desconhecidos e para obtenção de genomas completos, sendo o seu uso cada vez mais comum para a determinação de sequências genômicas de forma rápida e eficiente.

Palavras-chave: Amalgavirus, Sequenciamento de alto desempenho, Southern tomato virus, tomateiro. 


\section{Tomato virome analysis by next generation sequencing}

\section{ABSTRACT}

Tomato is a solanaceous plant that produces fruits containing compounds with antioxidant and anticancer properties. In 2015, the Brazilian production exceeded three million tonnes, being Goiás, Minas Gerais and São Paulo the biggest producers. This crop is targeted by several pathogens that can limit its production. The viruses cause some of the most important diseases, due to its wide spread in production fields and difficulty in its control. Diagnosis of phytopathogenic virus is usually performed by using techniques directed to known pathogens or to close variants, hence identification of unknown viruses is complex. The identification of undescribed viral species generally requires the application of a large selection of traditional and modern techniques. This process is, in general, slow and difficult. However, the improvement of large-scale sequencing techniques enabled the development of a new tool known as next generation sequencing-NGS. NGS has the property of sequencing all nucleic acids present in a sample producing lots of short sequences (reads), which are analyzed by bioinformatic tools for identification and assembly of complete sequences. In this work, five composite samples referred as BRAZ (Brazlândia-DF), AHOL, TOCA1, TOCA2 (Campinas$\mathrm{SP}$ ) and CAM-RNY2 (Araguari-MG) were submitted to semi-purification of viral particles and RNA extraction, and then to NGS for detection and identification of viral phytopathogens in tomato samples to get partial genomes by using bioinformatic tools. Several viruses commonly found in tomato fields in Brazil were detected in the composite samples, such as those of the genus: Tospovirus, Begomovirus, Tymovirus, Crinivirus, Tobravirus, Potexvirus and Amalgavirus. In addition, it enabled the detection and assembly of two semi-complete genomes of Southern tomato virus, a virus not reported in Brazil. The obtained genomes, STV DF and STV MG, covered, respectively, 3.418 and 3.415 nucleotides from a total of 3.437 nucleotides of the STV genome (NC_011591). The NGS is a useful tool for detection of known viruses or identification of unknown viruses, and to obtain their complete genomes. Its use is becoming common for a quick and efficient determination of genomic sequences.

Key-words: Amalgavirus, Next generation sequencing, Southern tomato virus, tomato. 


\section{INTRODUÇÃO}

O tomateiro é uma solanácea originária da América do Sul, atualmente cultivado em várias partes do mundo. Seu fruto possui altos teores de vitamina A e C, além de ser rico em licopeno, que possui propriedades antioxidantes e anticancerígenas (Makishima, 2011; Da Graça, 2013). A sua produção global duplicou nos últimos 20 anos, por conta do crescimento do consumo, que foi de $14 \mathrm{~kg}$ por pessoa por ano para $19 \mathrm{~kg}$. O crescente consumo também está relacionado com a sua consolidação nas redes de fast food (Carvalho \& Pagliuca, 2007). Em 2015, a safra brasileira de tomate foi de 3.686.816 toneladas, com 56.880 hectares plantados, sendo que os maiores estados produtores foram: Goiás, Minas Gerais e São Paulo (IBGE, 2016).

Esta cultura está sujeita a várias doenças que podem limitar sua produção. As viroses estão dentre as doenças de maior importância, pois diversos vírus têm sido descritos e estão amplamente disseminados nos campos de produção. Além disso, as doenças de etiologia viral são de difícil controle e não existem produtos anti-virais disponíveis no mercado (Kurozawa \& Pavan, 2005). Os principais gêneros virais com espécies responsáveis por perdas consideráveis nesta cultura no Brasil são Begomovirus, Crinivirus, Tospovirus, Tobamovirus e Potyvirus (Inoue-Nagata, 2013).

A detecção e identificação de vírus fitopatogênicos é realizada através de diversas técnicas baseadas em testes biológicos, sorológicos e moleculares que oferecem um diagnóstico confiável (Lima et al., 2015). Já o processo de identificação de vírus ainda não descritos ou de maneira não direcionada pode se constituir em uma tarefa difícil (Quan et al., 2008; Adams et al., 2009; Barba et al., 2014; Wu et al., 2015). A maior limitação para a diagnose de novas doenças causadas por vírus são as técnicas utilizadas que comumente são baseadas em testes diagnósticos direcionados a patógenos conhecidos, alvos da reação ou a 
variantes próximas, o que inviabiliza a detecção de vírus desconhecidos, para os quais ferramentas de detecção não estão disponíveis (Adams et al., 2009).

Nos últimos anos têm ocorrido avanços significativos no diagnóstico molecular de vírus em plantas. Com o aperfeiçoamento das técnicas de sequenciamento e das novas técnicas moleculares de diagnóstico viral é possível ampliar o conhecimento acerca do viroma (população viral) de diversas culturas de importância econômica.

O sequenciamento de alto desempenho determina a sequência de nucleotídeos massalmente de toda a população de ácidos nucleicos contidos em uma amostra, de modo a obter elevado rendimento de sequências curtas, conhecidas como reads (leituras). Os reads gerados são utilizados em análises de bioinformática para identificação e montagem de sequências de patógenos (Wang et al., 2009).

Essa técnica foi um marcante avanço na identificação e descoberta de vírus e está rapidamente se tornando um método comum, utilizado nas bancadas de laboratórios do mundo inteiro, principalmente para a obtenção de genomas completos de vírus de plantas em um período de tempo relativamente curto, ou de um enorme volume de informações sobre o genoma de forma rápida e precisa (Barba et al., 2014; Kehoe et al., 2014).

O sequenciamento de alto desempenho pode ser implementado no tomateiro para a detecção de vírus ainda não relatados na cultura ou no país. Na Espanha, por exemplo, a utilização dessa tecnologia em tomateiros resultou na detecção do Southern tomato virus STV em amostras coletadas no ano de 2006 (Verbeek et al., 2015).

O Southern tomato virus (STV), espécie-tipo do gênero Amalgavirus, foi descrito em 2009 na América do Norte (isolados dos Estados Unidos e do México) com suspeitas de associação com uma nova desordem em tomateiro. Esse vírus possui genoma composto de um RNA fita dupla com aproximadamente 3,5 Kb e duas fases de leitura aberta sobrepostas, que codificam a capa proteíca e a RNA polimerase (Sabanadzovic et al., 2009). STV foi relatado 
também na França, na Espanha, na China, em Bangladesh e na Itália, porém sempre detectado em co-infecção com outros vírus, o que dificulta o entendimento da sua sintomatologia (Verbeek et al., 2012; Candresse et al., 2013; Padmanabhan et al., 2015; Padmanabhan et al., 2015b; Iacono et al., 2015). A não transmissão por enxertia ou inoculação mecânica, e a incapacidade de purificação de virions de tomateiros infectados também complicam as análises realizadas com esse vírus (Sabanadzovic et al., 2009). Sua alta taxa de transmissão vertical e a expansão de sua distribuição gerou preocupações para a indústria do tomate, gerando uma demanda de pesquisas voltadas à caracterização biológica e aos efeitos da sua presença em sementes comerciais de diversas variedades (Sabanadzovic et al., 2009; Candresse et al., 2013).

O objetivo deste capítulo foi implementar a técnica de sequenciamento de alto desempenho para detectar e identificar patógenos virais presentes em amostras de tomateiro e obter genomas virais completos ou parciais através de ferramentas da bioinformática.

\section{MATERIAIS E MÉTODOS}

\section{Coletas}

As coletas foram realizadas em Brazlândia, no Distrito Federal, em Campinas, no estado de São Paulo e em Araguari no estado de Minas Gerais. As amostras de tomateiro apresentavam sintomas típicos de infecções virais, como clorose, manchas cloróticas, mosaico, distorção foliar, necrose, bolhosidade, rugosidade, dentre outros (Figura 5).

Em Brazlândia, amostras de sete plantas pertencentes as cultivares BRS Zamir e Serato foram coletadas em julho de 2015, na chácara Belmonte. A cultivar BRS Zamir (Agrocinco) apresenta níveis moderados de tolerância à infecção por begomovírus e a cultivar Serato (Agristar) possui resistência ao tospovírus Tomato spotted wilt virus e ao tobamovírus Tomato mosaic virus. Para a semi-purificação e o sequenciamento, as sete plantas foram agrupadas em uma amostra nomeada BRAZ. 
Em Campinas, a coleta foi realizada em novembro de 2014. As diversas plantas coletadas foram divididas em três grupos: AHOL, TOCA1, TOCA2.

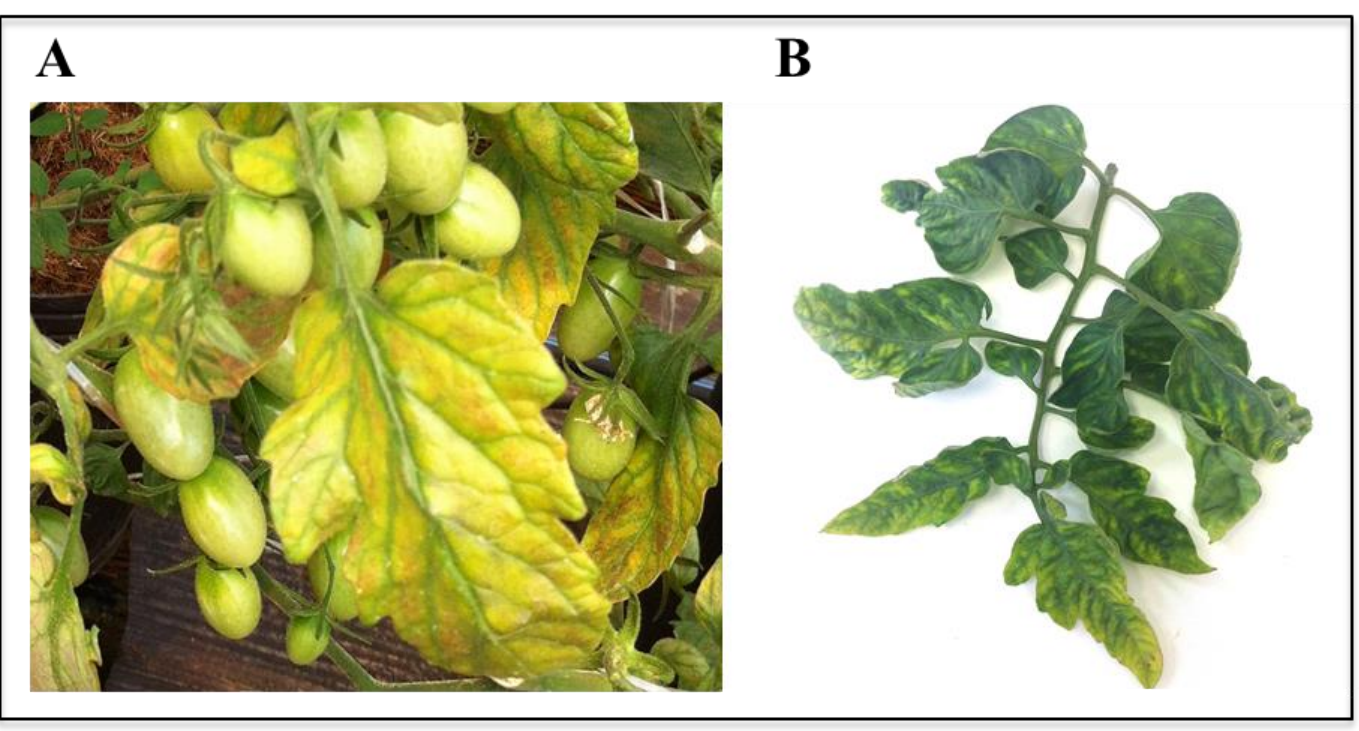

Figura 5: Tomateiros coletados em Brazlândia com sintomas típicos de infecções virais como clorose (A) e manchas cloróticas, bolhosidade e rugosidade (B).

O grupo AHOL foi coletado em Holambra e foi composto de tomateiros da cultivar Aguamiel (Vilmorin), relatada como resistente a ToMV, TSWV e begomovírus. Essas plantas apresentavam sintomas típicos de infecção por crinivírus e begomovírus.

O grupo TOCA1 foi composto de tomateiros da cultivar Giuliana (Sakata), suscetíveis à infecção por begomovírus. Enquanto a amostra composta TOCA2 continha plantas da cultivar Aguamiel (Vilmorim), resistentes a begomovírus, ToMV e TSWV. Ambos os grupos foram coletados na mesma área, diferindo apenas a cultivar.

O grupo CAM-RNY2 foi coletado em Araguari, Minas Geriais. É composto por plantas da cultivar Dominador (Agristar), coletadas em novembro de 2013, com sintoma de faixas necróticas e necrose em anel nas folhas. 


\section{Sequenciamento}

Os grupos de amostras BRAZ, AHOL, TOCA1, TOCA2 e CAM-RNY2 foram submetidas ao processo de semi-purificação de partículas virais. Aproximadamente 30 gramas de material foliar foram triturados em nitrogênio líquido (Figura 6A). Imediatamente após a pulverização do tecido foliar, foram adicionados $350 \mathrm{~mL}$ de tampão de semi-purificação, $\mathrm{pH} 8$ (EDTA 0,001 M, tampão fosfato $0,1 \mathrm{M}$ e $0,2 \%$ de $\beta$-mercaptoetanol, adicionado no momento do procedimento). Posteriormente o extrato foi filtrado em gaze (Figura 6B), e centrifugado a $3.900 \mathrm{~g}$ por 20 minutos. O sobrenadante foi centrifugado sob colchão de sacarose a $20 \%$ a 33.000 rotações por minuto (rotor Ti-45) por duas horas, para a precipitação das partículas virais (Figura 6C). O precipitado (Figura 6D) foi submetido a extração de RNA utilizando RNeasy ${ }^{\circledR}$ Minikit (Qiagen), conforme as recomendações do fabricante.
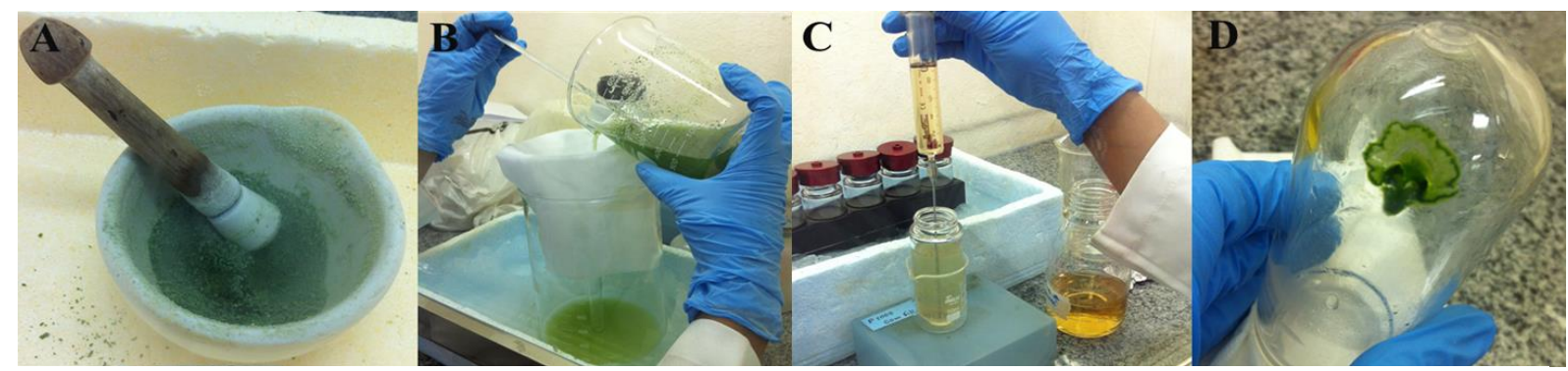

Figura 6: Etapas do processo de semi-purificação de partículas virais. (A) material foliar no almofariz após trituração em nitrogênio líquido; (B) extrato contendo o material foliar triturado e o tampão de purificação sendo filtrado em gaze; (C) aplicação de solução de sacarose a $20 \%$ no fundo do tubo contendo sobrenadante obtido após centrifugação; (D) precipitado formado no fundo do tubo após ultra-centrifugação a $33.000 \mathrm{rpm}$ (rotor Ti-45).

As amostras foram quantificadas e enviadas para sequenciamento na plataforma Illumina HiSeq2000, na Macrogen (Coréia do Sul).

\section{Análise de dados do sequenciamento}

Os adaptadores e reads com baixa qualidade (Phred<33) foram removidos das sequências obtidas utilizando Trimmomatic 0.35 (Bolger et al., 2014) e os contigs foram 
construídos com o algoritmo Velvet Assembler (Zerbino \& Birney, 2008) utilizando o comprimento de 29 kmer. Os contigs gerados foram transferidos para o programa Geneious 9.0.5 (Biomatters), onde foram submetidos à análise por MegaBLAST, contra sequências referência (RefSeq) do banco de dados. A análise determinou a sequência com maior identidade com o contig, número de acesso dessa sequência, porcentagem de identidade entre esse contig e a sequência e E-value. Adicionalmente, foi feita análise por tBLASTx dos contigs para comparação dos resultados.

\section{Montagem de genomas de STV}

Foram montadas duas sequências consenso de Southern tomato virus. Ambas foram montadas utilizando a ferramenta de mapeamento do Geneious, que permite a montagem de um genoma consenso utilizando os reads obtidos no sequenciamento e uma sequência referência como molde. A primeira foi nomeada como STV-DF e montada através do mapeamento dos reads da amostra BRAZ. A segunda foi montada com os reads da amostra CAM-RNY2 e nomeada como STV-MG. Essas bibliotecas foram escolhidas devido a maior cobertura da sequência-molde que apresentaram. A sequência-molde utilizada para montagem de ambos pertence a um isolado proveniente do México, depositado como sequência referência do STV (acesso NC_011591).

Após a montagem, as sequências-consenso foram alinhadas e comparadas a outras sequências de STV do banco de dados, utilizando SDT (Muhire et al., 2014) e Evolview v2 (Zhang et al., 2012). Todas as cinco sequências completas disponíveis de SDT, México (acesso NC_011591), Bangladesh (acesso KT634055), Carolina do Norte - EUA (acesso KT852573), Mississipi - EUA (acesso EU413670) e China (acesso KT438549), foram utilizadas. 


\section{Clonagem}

A clonagem foi feita de um fragmento de 440 pares de bases amplificado a partir da amostra BRAZ utilizando os primers STV3 (R) e STV3 (F) (Sabanadzovic et al., 2009). Para a clonagem foi utilizado o plasmídeo pGEM-T Easy (Promega) com 3.012 pares de bases. O inserto foi ligado ao plasmídeo através de reação contendo: $5 \mu \mathrm{L}$ de $2 \mathrm{X}$ rapid ligation buffer; $1 \mu \mathrm{L}$ de pGEM-T Easy (50 ng/ $\mu \mathrm{L}) ; 1 \mu \mathrm{L}$ de T4 DNA ligase $(3 \mathrm{U} / \mu \mathrm{L}$, Promega) e $3 \mu \mathrm{L}$ de inserto (aproximadamente $50 \mathrm{ng} / \mu \mathrm{L}$ ), incubado a $16^{\circ} \mathrm{C}$, por toda a noite. A ligação foi dialisada por 30 minutos utilizando membrana de diálise (Merck Millipore) em água ultrapura, para a retirada dos sais e $5 \mu \mathrm{L}$ foram utilizados para o processo de eletroporação em células competentes de Escherichia coli (cepa DH5 $\alpha$ ). Após a eletroporação, $500 \mu \mathrm{L}$ de meio LB líquido foram adicionados e a reação foi incubada a $37^{\circ} \mathrm{C}$ por uma hora.

Para o crescimento das bactérias, foram preparadas placas contendo aproximadamente $20 \mathrm{~mL}$ de meio LB-ágar com ampicilina a uma concentração de $100 \mu \mathrm{g} / \mu \mathrm{L}$. Após a solidificação completa do meio, foram acrescentados $100 \mu \mathrm{L}$ de IPTG 0,1 M (Isopropyl $\beta$-D1-thiogalactopyranoside) e $50 \mu \mathrm{L}$ de $\mathrm{X}$-gal $(20 \mathrm{mg} / \mathrm{mL})$ por placa. As placas foram vedadas e incubadas a $37{ }^{\circ} \mathrm{C}$ overnight para o crescimento das colônias. Foram selecionadas dez colônias que cresceram a $37^{\circ} \mathrm{C}$ durante toda a noite, em tubos de $15 \mathrm{~mL}$ contendo $5 \mathrm{~mL}$ de LB líquido. Após o crescimento foi realizada a extração do DNA plasmidial (miniprep) das bactérias, utilizando illustra plasmidPrep Mini Spin Kit (GE Healthcare), conforme as recomendações do fabricante.

Para a confirmação da clonagem, o DNA plasmidial extraído foi digerido com a enzima EcoRI, em reação que continha 5,8 $\mu \mathrm{L}$ de água milli-Q; $1 \mu \mathrm{L}$ de tampão; $0,2 \mu \mathrm{L}$ da enzima (20U/ $\mu \mathrm{L})$ e $3 \mu \mathrm{L}$ de DNA plasmidial. A reação foi incubada a $37{ }^{\circ} \mathrm{C}$ por 3 horas, a $65{ }^{\circ} \mathrm{C}$ por 15 minutos (inativação da enzima) e aplicada em gel de agarose 1\%. Para visualização das bandas foi utilizada solução de brometo de etídio e luz UV. O inserto do clone obtido, 
nomeado como pGEM-T Easy-STV 440 DF, foi sequenciado por sequenciador automático pela empresa Macrogen (Coréia do Sul).

\section{RESULTADOS}

\section{Sequenciamento de alto desempenho}

O sequenciamento de alto desempenho gerou um total de 8.802 .678 reads para a amostra BRAZ, 11.092.586 reads para a amostra AHOL, 7.837.442 reads para TOCA1, 11.225.386 para TOCA2 e 9.451.038 reads para CAM-RNY2. Os reads com índice de qualidade Phred maior que 20 (Q20) e que 30 (Q30) apresentaram uma taxa de aproximadamente 97 e 96\%, respectivamente, para todas as amostras, indicando sequências de ótima qualidade. Após a utilização do algoritmo Velvet Assembler foram obtidos 223.749 contigs da amostra BRAZ, 29.326 contigs da amostra AHOL, 25.144 contigs da amostra TOCA1, 49.016 contigs da amostra TOCA2 e 146.951 da amostra CAM-RNY2 (Tabela 2).

Tabela 2: Características dos reads obtidos pelo sequenciamento de alto desempenho.

\begin{tabular}{ccccc}
\hline Amostra & Total de reads & Reads $\mathbf{Q 2 0}(\%)^{\mathbf{1}}$ & Reads $_{\mathbf{~ Q 3 0}(\%)^{\mathbf{2}}}$ & $\mathbf{N}^{\mathbf{0}}$ de contigs $^{\mathbf{3}}$ \\
\hline BRAZ & 8.802 .678 & 97,7 & 96,2 & 223.749 \\
AHOL & 11.092 .586 & 97,8 & 96,2 & 29.326 \\
TOCA1 & 7.837 .442 & 97,9 & 96,3 & 25.144 \\
TOCA2 & 11.225 .386 & 97,9 & 96,3 & 49.016 \\
CAM-RNY2 & 9.451 .038 & 98,0 & 96,6 & 146.951 \\
\hline
\end{tabular}

${ }^{\mathrm{T}} \mathrm{Q} 20(\%)$ : proporção de reads com índice de qualidade Phred maior que 20;

${ }^{2} \mathrm{Q} 30(\%)$ : proporção de reads com índice de qualidade Phred maior que 30;

${ }^{3}$ Número de contigs obtidos através do Velvet Assembler.

\section{Vírus detectados por Next generation sequencing}

Após análise dos contigs por MegaBLAST e tBLASTx no programa Geneious, foram detectados hits que apresentavam identidade de nucleotídeos com as espécies virais superior a 77\%, incluindo representantes dos gêneros Tospovirus (Groundnut ringspot virus - GRSV e Tomato spotted wilt virus - TSWV), Potyvirus (Pepper yellow mosaic virus - PepYMV e 
Potato virus Y - PVY), Begomovirus (Sida micrantha mosaic virus - SiMMV, Tomato mottle leaf curl virus - ToMoLCV e Tomato severe rugose virus - ToSRV), Tymovirus (Tomato blistering mosaic virus - ToBMV), Crinivirus (Tomato chlorosis virus - ToCV), Ilarvirus (Parietaria mottle virus - PMoV e Ageratum latent virus - AgLV), Tobamovirus (Pepper mild mottle virus - PMMoV), Tobravirus (Pepper ringspot virus - PepRSV), Potexvirus (Potato virus X - PVX) e Amalgavirus (Southern tomato virus - STV) (Tabela 3).

Tabela 3: Análise por Megablast dos contigs obtidos em cada biblioteca.

\begin{tabular}{|c|c|c|c|c|c|c|}
\hline & $\begin{array}{l}\text { Compon. } \\
\text { genômico }\end{array}$ & $\begin{array}{c}\text { Comp. } \\
\text { do } \\
\text { maior } \\
\text { contig } \\
\text { (nt) } \\
\end{array}$ & $\begin{array}{c}\% \\
\text { de id. }\end{array}$ & $\begin{array}{c}\text { Cober- } \\
\text { tura } \\
(\%)\end{array}$ & E-value ${ }^{1}$ & $\begin{array}{l}\text { Acesso da } \\
\text { seq. usada } \\
\text { no BLAST }\end{array}$ \\
\hline \multicolumn{7}{|l|}{ BRAZ } \\
\hline Ageratum latent virus $-\mathrm{AgLV}^{3}$ & RNA1 & 1.309 & 77,3 & 67,8 & 0 & NC_022127 \\
\hline \multirow{3}{*}{ Groundnut ringspot virus - GRSV ${ }^{4}$} & RNA L & 341 & 98,2 & 100 & $3.02 \mathrm{e}-169$ & NC_015469 \\
\hline & RNA M & 377 & 96,8 & 100 & $9.26 \mathrm{e}-180$ & NC_015468 \\
\hline & RNA S & 504 & 99,0 & 99,4 & 0 & NC_015467 \\
\hline Parietaria mottle virus $-\mathrm{PMoV}^{4}$ & RNA2 & 1.495 & 79,1 & 76,9 & 0 & NC_005849 \\
\hline Pepper mild mottle virus - $\mathrm{PMMoV}^{3}$ & RNA & 153 & 99,3 & 100 & $5.07 \mathrm{e}-74$ & NC_003630 \\
\hline \multirow{2}{*}{ Pepper ringspot virus - PepRSV ${ }^{4}$} & RNA1 & 1.325 & 99,0 & 100 & 0 & NC_003669 \\
\hline & RNA2 & 310 & 97,8 & 100 & $6.04 \mathrm{e}-151$ & NC_003670 \\
\hline Sida micrantha mosaic virus $-\mathrm{SimMV}^{4}$ & DNA-A & 137 & 97,1 & 92,5 & $3.85 \mathrm{e}-60$ & NC_005330 \\
\hline Southern tomato virus $-\mathrm{STV}^{4}$ & RNA & 1.120 & 100 & 100 & 0 & NC_011591 \\
\hline Tomato blistering mosaic virus $-\mathrm{ToBMV}^{4}$ & RNA & 113 & 100 & 100 & $1.30 \mathrm{e}-53$ & NC_021851 \\
\hline \multirow{2}{*}{ Tomato chlorosis virus - ToCV ${ }^{4}$} & RNA1 & 659 & 99,2 & 100 & 0 & NC_007340 \\
\hline & RNA2 & 651 & 99,4 & 100 & 0 & NC_007341 \\
\hline Tomato mottle leaf curl virus - ToMoLCV ${ }^{2}$ & DNA-A & 464 & 98,7 & 97,6 & 0 & KC_706615 \\
\hline \multirow{2}{*}{ Tomato severe rugose virus - ToSRV ${ }^{4}$} & DNA-A & 415 & 99,0 & 100 & 0 & NC_009607 \\
\hline & DNA-B & 498 & 99,0 & 100 & 0 & NC_002556 \\
\hline \multicolumn{7}{|l|}{ AHOL } \\
\hline Southern tomato virus - $\mathrm{STV}^{4}$ & RNA & 382 & 99,7 & 100 & 0 & NC_011591 \\
\hline \multirow{2}{*}{ Tomato chlorosis virus - ToCV ${ }^{4}$} & RNA1 & 1.501 & 98,8 & 100 & 0 & NC_007340 \\
\hline & RNA2 & 1.658 & 99,1 & 100 & 0 & NC_007341 \\
\hline \multicolumn{7}{|l|}{ TOCA1 } \\
\hline Groundnut ringspot virus - GRSV ${ }^{4}$ & RNA S & 112 & 100 & 100 & $4.64 \mathrm{e}-53$ & NC_015467 \\
\hline Pepper yellow mosaic virus - PepYMV & RNA & 539 & 88,9 & 100 & 0 & NC_014327 \\
\hline Potato virus $\mathrm{Y}-\mathrm{PVY}^{4}$ & RNA & 4.062 & 89,5 & 99,9 & 0 & NC_001616 \\
\hline Southern tomato virus $-\mathrm{STV}^{4}$ & RNA & 441 & 100 & 100 & 0 & NC_011591 \\
\hline
\end{tabular}




\begin{tabular}{|c|c|c|c|c|c|c|}
\hline \multirow{2}{*}{ Tomato chlorosis virus - ToCV ${ }^{4}$} & RNA1 & 298 & 99,3 & 100 & $1.24 \mathrm{e}-152$ & NC_007340 \\
\hline & RNA2 & 1.102 & 98,8 & 100 & 0 & NC_007341 \\
\hline Tomato sereve rugose virus - ToSRV 3 & DNA-A & 132 & 100 & 100 & $4.30 \mathrm{e}-64$ & NC_009607 \\
\hline \multirow{3}{*}{ Tomato spotted wilt virus - $\mathrm{TSWV}^{4}$} & RNA L & 1.116 & 96,1 & 100 & 0 & NC_002052 \\
\hline & RNA M & 974 & 98,5 & 100 & 0 & NC_002050 \\
\hline & RNA S & 563 & 97,5 & 98,2 & 0 & NC_002051 \\
\hline \multicolumn{7}{|l|}{ TOCA2 } \\
\hline \multirow{2}{*}{ Pepper ringspot virus - PepRSV ${ }^{4}$} & RNA1 & 410 & 99,3 & 100 & 0 & NC_003669 \\
\hline & RNA2 & 546 & 98,7 & 100 & 0 & NC_003670 \\
\hline Southern tomato virus - $\mathrm{STV}^{4}$ & RNA & 262 & 100 & 100 & $5.15 \mathrm{e}-136$ & NC_011591 \\
\hline \multirow{2}{*}{ Tomato chlorosis virus - ToCV ${ }^{4}$} & RNA1 & 1.675 & 99,3 & 89,4 & 0 & NC_007340 \\
\hline & RNA2 & 1.853 & 99,2 & 100 & 0 & NC_007341 \\
\hline Tomato sereve rugose virus - ToSRV ${ }^{3}$ & DNA-A & 121 & 97,5 & 100 & $5.11 \mathrm{e}-53$ & NC_009607 \\
\hline \multicolumn{7}{|l|}{ CAM-RNY2 } \\
\hline \multirow{3}{*}{ Groundnut ringspot virus - GRSV ${ }^{4}$} & RNA L & 240 & 96,7 & 99,5 & $1.75 \mathrm{e}-110$ & NC_015469 \\
\hline & RNA M & 164 & 98,2 & 99,3 & $9.21 \mathrm{e}-77$ & NC_015468 \\
\hline & RNA S & 185 & 100 & 100 & $2.22 \mathrm{e}-93$ & NC_015467 \\
\hline Pepper mild mottle virus - $\mathrm{PMMoV}^{4}$ & RNA & 310 & 99,7 & 100 & $5.96 \mathrm{e}-161$ & NC_003630 \\
\hline Pepper ringspot virus - PepRSV ${ }^{4}$ & RNA2 & 150 & 98 & 100 & $4.99 e-69$ & NC_003670 \\
\hline Potato virus $\mathrm{X}-\mathrm{PVX}^{4}$ & RNA & 163 & 96,3 & 99,3 & $3.31 \mathrm{e}-71$ & NC_011620 \\
\hline Potato virus $\mathrm{Y}-\mathrm{PVY}^{5}$ & RNA & 129 & 100 & 97,7 & $2.59 \mathrm{e}-23$ & NC_001616 \\
\hline Southern tomato virus $-\mathrm{STV}^{4}$ & RNA & 1.077 & 100 & 100 & 0 & NC_011591 \\
\hline Tomato blistering mosaic virus $-\mathrm{ToBMV}^{4}$ & RNA & 236 & 100 & 100 & $1.30 \mathrm{e}-121$ & NC_021851 \\
\hline \multirow{2}{*}{ Tomato chlorosis virus - ToCV } & RNA1 & 1.495 & 99,3 & 100 & 0 & NC_007340 \\
\hline & RNA2 & 5.442 & 99 & 100 & 0 & NC_007341 \\
\hline
\end{tabular}

${ }^{1}$ Corresponde à probabilidade de se obter, com outra seqüência aleatória de mesmo tamanho e composição de letras, outro alinhamento com score igual ou superior (de Sousa \& Lifschitz, 2007);

${ }^{2} \mathrm{~A}$ análise para esse vírus foi realizada por Megablast usando nucleotide collection apenas de geminivírus;

${ }^{3}$ Detectado apenas por análise Megablast;

${ }^{4}$ Detectado por análises Megablast e Blastx;

${ }^{5}$ Detectado apenas por análise Blastx.

A maioria dessas sequências tem uma alta identidade de nucleotídeos com vírus conhecidos, exceto a sequência que demonstrou $77,3 \%$ de identidade com Ageratum latent virus - AgLV e aquela que demonstrou $79,1 \%$ de identidade com Parietaria mottle virus PMoV. 
Os vírus ToCV e STV foram encontrados em todas as bibliotecas, PMMoV e ToBMV foram detectados nas bibliotecas BRAZ e CAM-RNY2, ToSRV nas bibliotecas BRAZ, TOCA1 e TOCA2 e PepRSV nas bibliotecas BRAZ, TOCA2 e CAM-RNY2. Os vírus similares a AgLV, PMoV, SiMMV e ToMoLCV foram encontrados somente em Brazlândia. Os tospovírus TSWV e GRSV foram detectados na biblioteca TOCA1 de Campinas, enquanto nas bibliotecas BRAZ e CAM-RNY2 só foi encontrado o GRSV. O PVY foi encontrado na amostra TOCA1 e o PVX, na amostra CAM-RNY2.

\section{O genoma de STV}

O STV foi encontrado em todas as amostras e selecionado para uma caracterização detalhada focando as sequências obtidas das amostras BRAZ e CAM-RNY2, por apresentarem as maiores coberturas do genoma.

O genoma STV da biblioteca BRAZ obtido por sequenciamento de alto desempenho cobriu 3.418 nucleotídeos de um genoma total com 3.437 nucleotídeos (acesso NC_011591), faltando os doze primeiros e os sete últimos nucleotídeos, nas regiões 5' UTR e 3' UTR, respectivamente (Figura 9A). O fragmento que se inicia no nucleotídeo 1.139 ao nucleotídeo 1.324 não apresentou cobertura dos reads, mas foi obtido por amplificação da região por RTPCR, utilizando primers descritos por Sabanadozovic et al. (2009), clonagem e sequenciamento.

A clonagem do fragmento obtido a partir da amostra BRAZ com o par de primers STV3 foi realizada para complementação da sequência genômica do STV-DF. A digestão do plasmídeo pGEM-T Easy-STV 440 DF 1 com Eco RI resultou na visualização de duas bandas em gel de agarose a 1\%, uma de 3.000 bp e outra de aproximadamente 500 bp (Figura 7), confirmando a clonagem do fragmento amplificado anteriormente. O clone foi então enviado para sequenciamento na Macrogen (Coréia do Sul). 


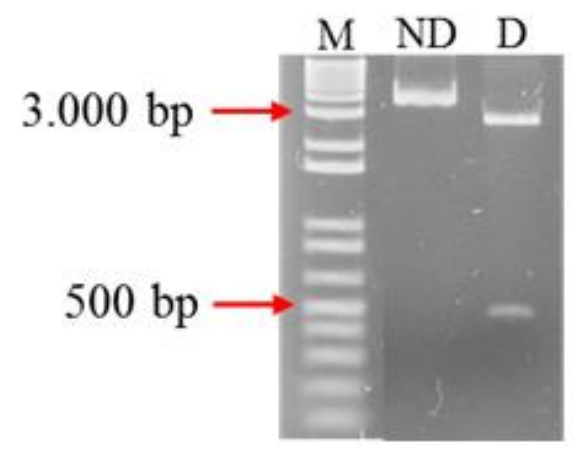

Figura 7: Gel de agarose mostrando plasmídeo p-GEM-T Easy-STV 440 DF 1 não digerido (ND) e plasmídeo p-GEM-T Easy-STV 440 DF 1 digerido com a enzima EcoRI (D). Marcador utilizado: $1 \mathrm{~Kb}$ Plus (Invitrogen).

Após o sequenciamento do plasmídeo pGEM-T easy-STV 440 DF 1, a sequência resultante foi alinhada a sequência do genoma STV-DF (Figura 8). Os nucleotídeos da sequência STV-DF que não foram cobertos pelos reads na análise por sequenciamento de alto desempenho, do nucleotídeo 1.139 ao 1.324 , foram então obtidos. O fragmento amplificado compreendeu a região do nucleotídeo 1.139 ao 1.324 do genoma do STV. Dois clones foram obtidos e a sequência do clone 1 foi utilizada para a montagem do genoma semi-completo, faltando apenas as extremidades 5' e 3' do genoma denominado STV-DF.

O genoma STV da biblioteca CAM-RNY2 iniciou-se no nucleotídeo 13 até o nucleotídeo 3.415, cobrindo 3.403 nucleotídeos de um genoma total com 3.437 nucleotídeos (acesso NC_011591) e foi denominado STV-MG. Os doze primeiros e os 22 últimos nucleotídeos nas regiões 5' UTR e 3' UTR, respectivamente, não foram cobertos pelos reads obtidos no sequenciamento (Figura 9B). Não foram realizados mais experimentos para completar a sequência. 


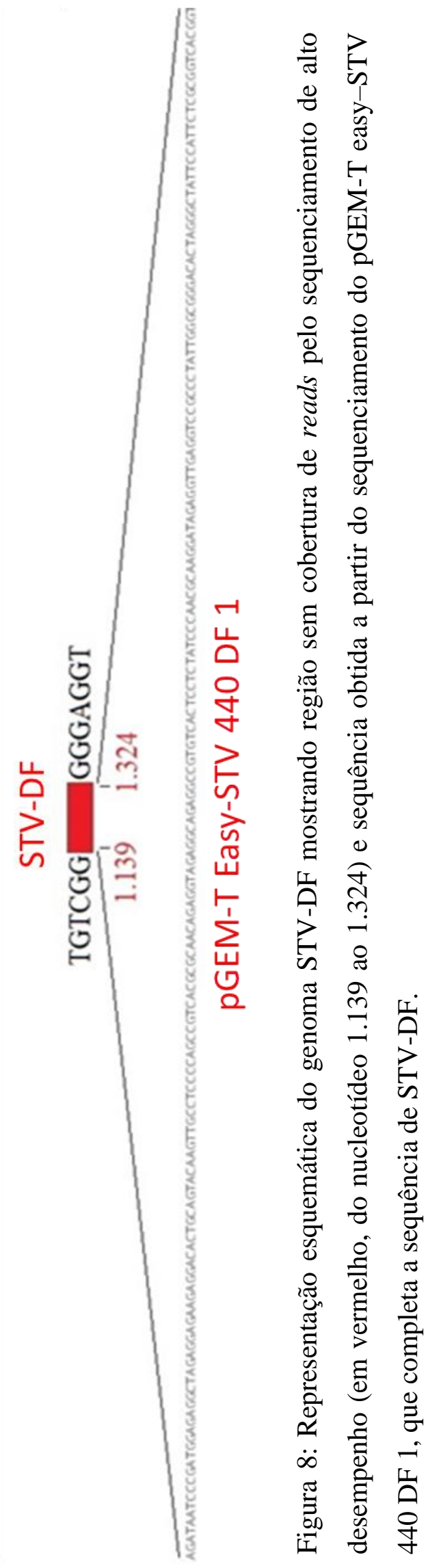




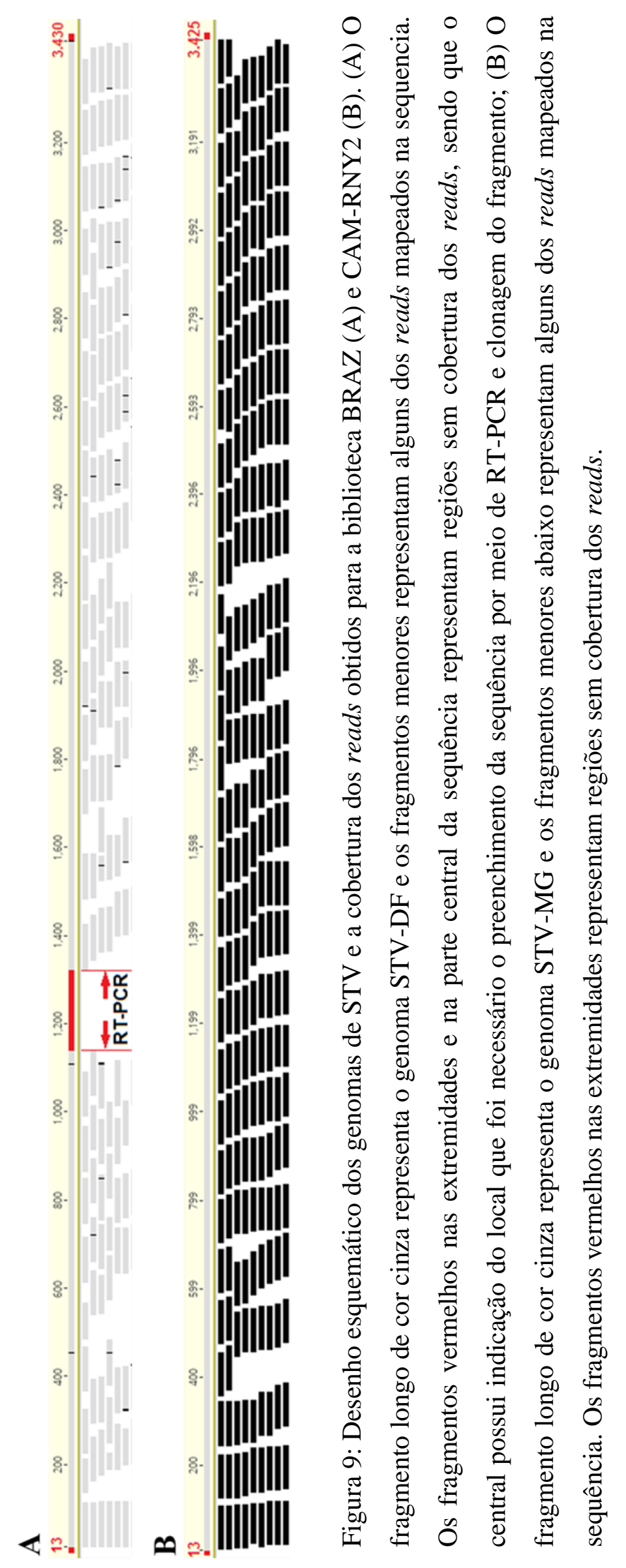


A cobertura dos genomas foi de 432 reads para STV-DF e de 1.249 reads para STVMG. Os genomas de STV (STV-DF e STV-MG) foram comparados com outras sequências de STV disponíveis em banco de dados públicos de sequências. A sequência de STV-DF e STVMG compartilham entre si $99,9 \%$ de identidade de nucleotídeos pelo programa SDT. A comparação feita entre o genoma de STV-DF e STV-MG revelou identidade de nucleotídeos entre 99,1 a 100,0\% entre todas as sequências disponíveis de STV (Figura 10). Isso indicou uma alta uniformidade de sequência entre eles.

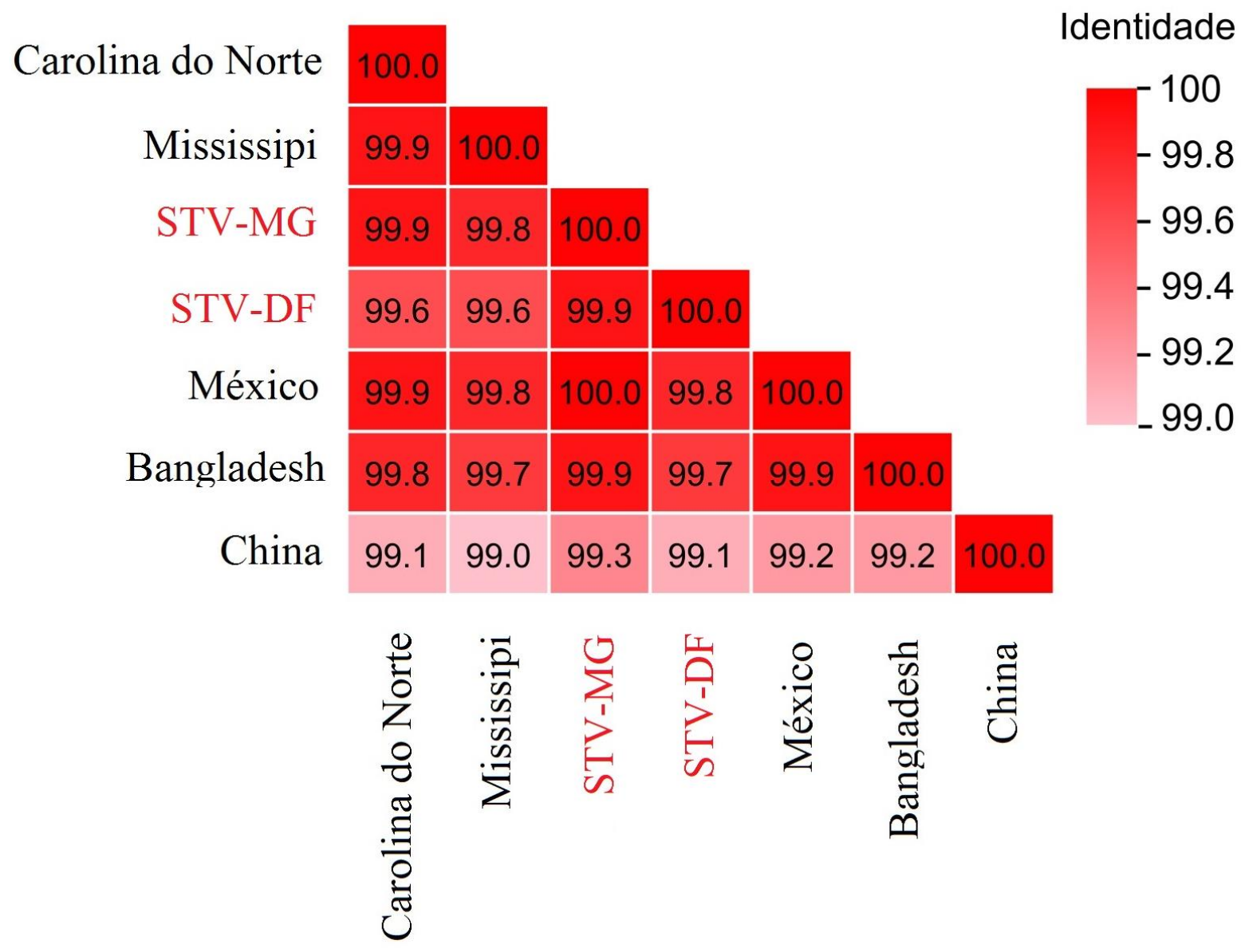

Figura 10: Matriz de comparação em cores e com porcentagem, entre os isolados de STV do Brasil (DF e MG) e todas as sequências de STV disponíveis em bancos de dados: Carolina do Norte (acesso KT852573), Mississipi (acesso EU413670), México (acesso NC_011591), Bangladesh (acesso KT634055) e China (acesso KT438549). 


\section{DISCUSSÃO}

O sequenciamento de alto de desempenho foi eficiente para a detecção de vírus frequentemente relatados em tomateiro. Diversos vírus encontrados na análise são relatados no país e encontrados comumente em campos de produção de tomate. A detecção de vírus como GRSV, TSWV, PepRSV, ToCV, SiMMV, ToSRV, ToBMV, PepYMV e PVY era esperada devido aos relatos de sua ocorrência em estudos anteriores, que será melhor detalhada a seguir.

Os dois tospovírus (TSWV e GRSV) detectados em Campinas (TOCA1) são relatados entre os quatro vírus causadores da doença conhecida como "vira-cabeça do tomateiro" (Nagata et al., 1998; Bezerra et al., 1999). Isolados das espécies TSWV e GRSV são os mais frequentemente relatados no Brasil e causam prejuízos em tomateiros e pimenteiras (Resende et al., 1996; Bezerra et al., 1999; Inoue-Nagata, 2013).

O GRSV, detectado em Brazlândia, Campinas (TOCA1) e Minas Gerais, ocorre em poucos países e, no Brasil, é considerado o tospovírus predominante (Nagata et al., 1995; Resende et al., 1996; Lima et al., 2000, Bertran et al., 2011). Estudos de sua distribuição geográfica no início da década de 1990 demonstraram a grande expansão desse vírus do Nordeste para a região central do Brasil, explicada pela alta eficiência de transmissão pela espécie Frankliniella schultzei (de Ávila et al., 1996; Lima et al., 2000; Nagata et al., 2004).

Os demais tospovírus causadores do "vira-cabeça do tomateiro", TCSV e CSNV, já foram relatados nos campos de produção de tomate no Brasil, inclusive em São Paulo (Resende et al., 1996; Duarte et al., 1996), porém nessa análise não foram encontrados. A ausência de sequências correspondentes ao TCSV e CSNV sugere que TSWV e GRSV são os tospovírus mais encontrados na região. Sequências de tospovírus foram encontradas em bibliotecas produzidas a partir de tomateiro de cultivares suscetíveis a tospovírus, como 
BRAZ (Zamir), TOCA1 (Giuliana) e CAM-RYN2 (Dominador), sugerindo uma boa eficiência da expressão da resistência na cultivar Aguamiel.

O tobravírus PepRSV foi detectado em Brazlândia, Minas Gerais e Campinas (TOCA2). Esse vírus foi descrito no Brasil infectando pimentão (Kitajima \& Costa, 1969), pimenta, fumo (Kitajima \& Costa, 1969b) e tomateiro (Costa \& Kitajima, 1968). É um vírus pouco estudado e naturalmente transmitido por nematoides (Rodrigues et al., 2015). Sua ocorrência é restrita ao país até o momento (MacFarlane, 1999; Rodrigues et al., 2015), sendo que os resultados aqui relatados sugerem uma ampla distribuição do vírus nas principais regiões de produção no DF, MG e SP.

O crinivírus Tomato chlorosis virus foi encontrado em todas as bibliotecas. No Brasil, a presença do ToCV foi relatada pela primeira vez por Barbosa et al. (2008) na região de Sumaré, estado de São Paulo. Em 2011 foi relatado em outros estados, incluindo o Distrito Federal (Barbosa et al., 2011; Nogueira et al., 2011; Quezado-Duval et al, 2013). De acordo com Macêdo et al. (2014), esse vírus tem sido frequentemente detectado nas regiões produtoras do DF, o que tem aumentado sua importância. Devido à semelhança dos sintomas provocados por ToCV em tomateiro com os sintomas induzidos por begomovirose e potyvirose, a presença desse vírus nos campos de produção de tomate do Brasil provavelmente passou despercebida por muitos anos, porém, observações realizadas nas lavouras de regiões produtoras de Goiás, São Paulo e Espírito Santo demonstram que essa virose está em expansão (Inoue-Nagata, 2013).

Em Brazlândia e Minas Gerais, foi encontrado o Tomato blistering mosaic virus (ToBMV). Essa espécie de tymovírus foi descrita a poucos anos infectando tomateiros no estado de Santa Catarina (de Oliveira et al., 2013) e pouco se sabe sobre sua distribuição geográfica, mas esse relato demonstra que ele pode estar mais largamente distribuído do que 
se imagina. Recentemente, esse vírus foi relatado infectando tomateiros na Argentina (Ferrand et al., 2016) e Solanum violaefolium no Brasil (Blawid et al., 2016).

Estudos adicionais com a detecção do ToBMV em tomateiros de Campinas e Brazlândia são necessários para confirmar a sua ampla distribuição nas regiões produtoras do Sudeste e do Centro-Oeste. Por ser um vírus de relato recente, há uma demanda por estudos relacionados à biologia desse vírus, pois características como sua forma de transmissão, epidemiologia e possíveis métodos de controle não são conhecidos (Inoue-Nagata, 2013).

O potyvírus PVY foi encontrado nas amostras TOCA1 de Campinas e CAM-RNY2 de Minas Gerais, enquanto PepYMV foi encontrado apenas na amostra TOCA1. O PVY apresenta distribuição mundial, porém o uso de cultivares resistentes no Brasil, desde a década de 90, reduziu a importância desses vírus nas lavouras (de Oliveira, 2014).

Uma nova estirpe de PVY capaz de superar a resistência em pimentão foi relatada (Nagai, 1983). Posteriormente, Inoue-Nagata et al. (2002) denominaram essa estirpe como uma nova espécie: Pepper yellow mosaic virus, com base em análises filogenéticas que revelaram baixa relação deste com isolados típicos de PVY (de Oliveira, 2014). Em 2004, foram relatadas perdas de até $100 \%$ em cultivos de tomateiro em regiões produtoras do Espírito Santo causadas pelo PepYMV (Maciel-Zambolim et al., 2004) e em 2008, foi registrada uma alta incidência desse vírus em Taquara, no Distrito Federal (Dianese et al., 2008). Regiões produtoras de São Paulo e Goiás também foram relatadas com a presença desse vírus em 2014 (Quezado-Duval et al., 2014). A detecção do PepYMV era esperada, devido ao crescimento de sua incidência observado nos últimos anos. Acredita-se que o PVY teve sua importância diminuida após a introdução das variedades resistentes e a ocupação de seu nicho pelo PepYMV (Dianese et al., 2008). Esses potyvírus parecem ocorrer normalmente nas lavouras e eventualmente podem se tornar um problema. 
O PVX foi encontrado apenas em Minas Gerais. Esse potexvírus encontra-se disseminado no mundo inteiro, porém possui uma gama de hospedeiras restrita dentro da família Solanaceae, causando danos em batata, como a diminuição no tamanho e na quantidade de tubérculos (Silva et al., 2005). Apesar dessa detecção, o PVX não é um vírus considerado importante para a cultura do tomateiro.

O Pepper mild mottle virus (PMMoV) é um vírus pertencente ao subgrupo 1 do gênero Tobamovirus. Esse vírus ocorre mundialmente e é considerado um dos patógenos mais importantes de culturas de pimenta (Oka et al., 2008). No Brasil, é relatado infectando plantas de pimenta e pimentão desde 2001, com sintomas de amarelecimento foliar suave, deformações dos frutos e subdesenvolvimento das plantas (Cezar et al., 2009; de Almeida, 2013). O vírus foi detectado em Brazlândia e na amostra CAM-RNY2 de Campinas, um resultado inesperado, pois em casos de ocorrência de tobamovirose em tomateiro, invariavelmente o ToMV é encontrado (Inoue-Nagata, 2013). Mais estudos devem ser conduzidos com o objetivo de confirmar a presença desse vírus nessas amostras, pois seria o primeiro relato do PMMoV em tomateiro. Um fato interessante é a presença desse vírus em amostras com plantas com resistência a ToMV como na biblioteca de Brazlândia (BRS Zamir e Serato) e CAM-RYN2 (Dominador).

Os begomovírus pertencem à família Geminiviridae e possuem genoma composto por um ou dois segmentos de DNA circular fita simples e são transmitidos por moscas-brancas (Stanley et al., 2005; Melgarejo et al., 2013). Os begomovírus detectados neste estudo foram ToSRV (detectado em Brazlândia e Campinas), SiMMV e ToMoLCV (detectados apenas em Brazlândia). A detecção do ToSRV e do ToMoLCV são frequentes em diversos trabalhos realizados no Brasil, sendo que o ToSRV representa uma das espécies mais importantes para a tomaticultura (Ribeiro et al., 2003; Fernandes et al., 2008; Albuquerque et al., 2012). Já detecção do SiMMV não era esperada devido à prevalência dos begomovírus citados 
anteriormente. A detecção do ToMoLCV foi realizada a partir de análise Megablast contra o banco de dados apenas com sequências de geminivírus realizada devido à inexistência de uma sequência referência desse vírus no banco de dados. Esse vírus foi relatado no Distrito Federal por diversos autores (Fernandes et al., 2008; Albuquerque et al., 2012; Rêgo, 2016). Apesar de begomovírus já terem sido relatados no estado de Minas Gerais por Fernandes et al. (2008), neste trabalho não foram encontrados na biblioteca CAM-RNY2. Os begomovírus Tomato golden vein virus (TGVV) e o Tomato chlorotic mottle virus (ToCMoV) com ocorrência registrada na região do Distrito Federal (Albuquerque et al., 2012), não foram encontrados nessa análise.

A detecção de vírus com componente genômico de DNA pela análise de sequênciamento de alto desempenho de RNA é possível porque a extração do RNA das amostras também possibilita a análise do transcriptoma, ou seja, do conjunto de transcritos contidos em uma célula (Wang et al., 2009). Isso constitui outra vantagem do sequenciamento de alto desempenho, a detecção de vírus com genomas constituidos de RNA e DNA através do sequenciamento somente de RNA.

Alguns dos vírus encontrados não haviam sido relatados no país até o momento, como o Ageratum latent virus (AgLV), o Parietaria mottle virus (PMoV) e o Southern tomato virus (STV). A detecção dos primeiros dois vírus, que são ilarvírus, levantaram fortes suspeitas da existência de uma nova espécie viral desse gênero. O contig de 1.309 nucleotídeos com 77,3\% de identidade de nucleotídeos com o RNA1 do ilarvírus Ageratum latent virus e o contig de 1.495 nucleotídeos com 79,1\% de identidade com o RNA2 do ilarvírus Parietaria mottle virus. Essa porcentagem de identidade de nucleotídeos com os ilarvírus conhecidos foi considerada baixa, apesar do critério de demarcação de espécies do gênero Ilarvirus a partir da similaridade das sequências não ter uma definição. 
O gênero Ilarvirus pertence à família Bromoviridae. Esses vírus possuem genoma composto por três RNAs fita simples senso positivo e são transmitidos mecanicamente por tripes que se alimentam dos graõs de pólen contendo o vírus ou simplesmente pela dispersão desses grãos de pólen contaminados pelo vento (Bujarski et al., 2011). Os ilarvírus infectam predominantemente plantas lenhosas e causam doenças de importância econômica em plantas dos gêneros Citrus, Humulus, Malus, Prunus, Rosa e Rubus. A busca de mais informações sobre esses vírus enfrenta dificuldades em seu manuseio e na manipulação, pois são vírus de difícil isolamento de seus hospedeiros lenhosos e sua transmissão mecânica não é fácil (Untiveros et al., 2010). Suspeita-se que esses dois contigs pertençam a RNAs de uma possível espécie nova do gênero Ilarvirus. Mais estudos relacionados à sorologia, a gama de hospedeiras e a sequência de nucleotídeos desse isolado serão conduzidos para confirmar a presença de um ilarvirus já existente ou uma nova espécie.

O amalgavírus Southern tomato virus não foi até o momento relatado no país, porém a partir do sequenciamento de alto desempenho foi encontrado em todas as bibliotecas. Os genomas de STV montados (STV-DF e STV-MG) mostraram alta identidade de nucleotídeos entre eles e com os demais isolados de STV do mundo, indicando que os isolados encontrados no Brasil são muito parecidos entre si e com outros isolados de STV relatados no mundo. O STV gerou preocupações devido à sua frequente detecção em sementes comerciais e sua alta taxa de transmissão vertical, que pode variar entre 70 e $90 \%$ dependendo da cultivar (Sabanadzovic et al., 2009; Candresse et al., 2013). Mais pesquisas envolvendo a biologia e as características moleculares desse vírus devem ser conduzidas para investigar o efeito da sua presença e definir uma resposta final para sua sintomatologia (Iacono et al., 2015). Estudos adicionais foram realizados e relatados no Capítulo 3.

Diversas vantagens podem ser citadas para o uso do sequenciamento de alto desempenho neste trabalho. $\mathrm{O}$ aperfeiçoamento dos métodos de sequenciamento genético 
através dessa tecnologia tem possibilitado grandes avanços na identificação de novos agentes virais. Ela permite a identificação de todo o viroma (genomas virais) presente em uma determinada hospedeira, incluindo populações virais altamente divergentes, as quais seriam difíceis de serem detectadas com base nas técnicas moleculares comumente utilizadas (Metzker, 2010; Radford et al., 2012).

Dentre as vantagens de sua utilização neste trabalho, destaca-se a detecção de um vírus de tomateiro considerado até o momento como assintomático, o STV. A identificação de diversos vírus no campo começa com a observação dos sintomas, logo, sem a realização do sequenciamento de alto desempenho, poderiam se passar anos até que houvesse suspeitas da presença desse vírus em sementes comerciais plantadas no país. A técnica também nos dá a oportunidade de obtenção de genomas completos ou quase completos de vírus de plantas, devido ao tamanho relativamente curto desses genomas (Kehoe et al., 2014). Este trabalho resultou na montagem de dois genomas semi-completos do vírus STV, com aproximadamente 3.400 pares de bases, utilizando as ferramentas de bioinformática.

Outro resultado da utilização dessa técnica foi a detecção de um potencial novo ilarvírus em tomateiro. Apesar da existência de primers degenerados que podem ajudar na detecção de uma nova espécie, os estudos com ilarvírus são escassos e a identificação de uma nova espécie exigiria mais tempo e uma análise mais aprofundada se realizada apenas por métodos tradicionais (Untiveros et al., 2010; Wu et al., 2015).

O ToMV e o CMV, frequentemente relatados nas lavouras do Brasil, inclusive no DF e em MG (Quezado-Duval et al., 2013), não foram encontrados nesse estudo. Assim como vírus que são considerados emergentes para essa cultura e são relatados em outros locais do mundo, como Tomato infectious chlorosis virus, Pepino mosaic virus, Tomato torrado virus e o Tomato yellow leaf curl virus (Hanssen et al., 2010), não foram relatados nas regiões analisadas. 
A utilização do sequenciamento de alto desempenho entre os virologistas vegetais está aumentando à medida que o custo associado a ele diminui. Os desafios agora consistem na utilização correta da enorme quantidade de dados gerada através das ferramentas de bioinformática disponíveis (Kehoe et al., 2014). 


\section{CONCLUSÕES}

Vírus comumente encontrados em lavouras de tomateiro brasileiras como GRSV, TSWV, ToCV, ToSRV, PepYMV e PVY puderam ser detectadas em tomateiros de Brazlândia, Campinas e Minas Gerais.

A detecção do PMMoV em amostras de tomateiro foi um resultado inesperado, devido aos casos de ocorrência de tobamovirose em tomateiro serem invariavelmente causados por ToMV.

A baixa identidade de nucleotídeos de dois contigs da amostra BRAZ com dois vírus do gênero Ilarvirus, Ageratum latent virus e Parietaria mottle virus, levantou uma forte suspeita da existência de uma nova espécie desse gênero infectando o tomateiro.

A primeira detecção do STV em tomateiro no Brasil foi realizada.

A montagem de dois genomas de STV, um de Brazlândia e um de Minas Gerais, foi possível a partir do uso do sequenciamento de alto desempenho e da bioinformática.

O sequenciamento de alto desempenho detecta vírus de DNA e RNA concomitantemente, pois a extração do RNA das amostras possibilita a análise do transcriptoma.

O sequenciamento de alto desempenho é uma ferramenta útil para a detecção de espécies virais conhecidas ou não, e para a obtenção de genomas parciais/completos de vírus em tomateiro. 


\section{LITERATURA CITADA}

ADAMS, I.P.; GLOVER, R.H.; MONGER, W.A.; MUMFORD, R.; JACKEVICIENE, E.; NAVALINSKIENE, M.; SAMUITIENE, M. \& BOONHAM, N. 2009. Next generation sequencing and metagenomic analysis: a universal diagnostic tool in plant virology. Molecular Plant Pathology 10: 537-545.

ALBUQUERQUE, L.C.; VARSANI, A.; FERNANDES, F.R.; PINHEIRO, B.; MARTIN, D.P.; FERREIRA P.T.O.; LEMOS, T.O. \& INOUE-NAGATA, A.K. 2012. Further characterization of tomato-infecting begomoviruses in Brazil. Archives of Virology 157: 747-52.

ALBUQUERQUE, L.C.; VARSANI, A.; FERNANDES, F.R.; PINHEIRO, B.; MARTIN, D.P.; FERREIRA, P.T.O.; LEMOS, T.O. \& INOUE-NAGATA, A.K. 2012. Further characterization of tomato-infecting begomoviruses in Brazil. Archives of Virology 157: 747-752.

BARBA, M.; CZOSNEK, H. \& HADIDI, A. 2014. Historical perspective, development and applications of next generation sequencing in plant virology. Viruses 6: 106-136.

BARBOSA, J.C.; COSTA, H.; GIORIA, R. \& REZENDE, J.A.M. 2011. Occurrence of Tomato chlorosis virus in tomato crops in five Brazilian states. Tropical Plant Pathology 36(4): 256-258.

BARBOSA, J.C.; TEIXEIRA, A.P.M.; MOREIRA, A.G.; CAMARGO, L.E.A.; FILHO, A.B.; KITAJIMA, E.W. \& REZENDE, J.A.M. 2008. First report of Tomato chlorosis virus infecting tomato crops in Brazil. Plant Disease 92(2): 1709.

BERTRAN, A.G.M.; OLIVEIRA, A.S.; NAGATA, T. \& RESENDE, R.O. 2011. Molecular characterization of the RNA-dependent RNA polymerase from Groundnut ringspot virus (genus Tospovirus, family Bunyaviridae). Archives of virology 156(8): 14251429 .

BEZERRA, I.C.O.; RESENDE, R.; POZZER, L.; NAGATA, T.; KORMELINK, R. \& DE ÁVILA, A.C. 1999. Increase of tospoviral diversity in Brazil with the identification of two new tospovirus species, one from chrysanthemum and one from zucchini. Phytopathology 89(9): 823-830.

BLAWID, R.; HAYASHI, E.A.I.; REZENDE, J.A.M.; KITAJIMA, E.W. \& NAGATA, T. 2016. A highly divergent isolate of tomato blistering mosaic virus from Solanum violaefolium. Virus genes 52(2): 294-298.

BOLGER, A.M.; LOHSE, M. \& USADEL, B. 2014. Trimmomatic: a flexible trimmer for 
illumina sequence data. Bioinformatics 5: 2114-2120.

BUJARSKI, J.; FIGLEROWICZ, M.; GALLITELLI, D.; ROOSSINCK, M.J. \& SCOTT, S.W. 2011. Genus Ilarvirus. In: KING, A.; LEFKOWITZ, E.; ADAMS, M. J.; CARSTENS, E.B. Virus Taxonomy: Ninth Report of the International Committee on Taxonomy of Viruses. Elsevier Academic Press, San Diego, Califórnia. p. 972-975.

CANDRESSE, T.; MARAIS, A. \& FAURE, C. 2013. First report of Southern tomato virus on tomatoes in Southwest France. Plant Disease 97, 1124.

CARVALHO, J.L. \& PAGLIUCA, L.G. 2007. Tomate - um mercado que não pára de crescer. Hortifruti Brasil 58: 6-14.

CASTILLO-URQUIZA, G.P.; BESERRA JR, J.E.A.; BRUCKNER, F.P.; LIMA, A.T.; VARSANI, A.; ALFENAS-ZERBINI, P. \& ZERBINI, F.M. 2008. Six novel begomoviruses infecting tomato and associated weeds in Southeastern Brazil. Archives of virology 153(10): 1985-1989.

CASTILLO-URQUIZA, G.P.; BESERRA-JR, J.E.A.; BRUCKNER, F.P.; LIMA, A.T.; VARSANI, A.; ALFENAS-ZERBINI, P. \& ZERBINI, F.M. 2008. Six novel begomoviruses infecting tomato and associated weeds in Southeastern Brazil. Archives of Virology 153: 1985-9.

CEZAR, M.A.; KRAUSE-SAKATE, R.; PAVAN, M.A. \& COSTA, C.P.D. 2009. Avaliação da resistência a tobamovirus em acessos de Capsicum spp. Summa Phytopathologica 35(1): 39-43.

COSTA, A. S. \& KITAJIMA, E. W. 1968. Transmissão do virus do anel do pimentão através da semente do tomate. Revista da Sociedade Brasileira de Fitopatologia 2: 25.

COSTA, A.S. \& KITAJIMA, E.W. 1968. Transmissão do virus do anel do pimentão através da semente do tomate. Revista da Sociedade Brasileira de Fitopatologia 2: 25.

DA GRAÇA, A.J.P. 2013. Heterose e capacidade combinatória de linhagens de tomateiro (Solanum lycopersicum L.) prospectadas para dupla finalidade. Dissertação de Mestrado. Universidade Estadual do Norte Fluminense Darcy Ribeiro, Rio de Janeiro, Brasil.

DE ALMEIDA, J.E.M.D. 2013. Detecção e transmissibilidade de vírus em sementes de abóbora, pimentão e tomate. Tese de doutorado. Universidade Federal de Lavras. Minas Gerais, Brasil.

DE ÁVILA, A.C.; LIMA, M.F.; RESENDE, R.O.; POZZER, L.; FERRAZ, E.; MARANHÃO, E.A.A.; CANDEIA, J.A. \& COSTA, N.D. 1996. Identificação de tospovírus em hortaliças no submedio São Francisco utilizando DAS-ELISA e Dot- 
ELISA. Fitopatologia Brasileira 21: 503-508.

DE OLIVEIRA, R.M. 2014. Análises da resistência genética à Tospovirus e Potyvirus em acessos de Solanum (secção Lycopersicon). Dissertação de Mestrado. Universidade Federal de Goiás, Goiás, Brasil.

DE OLIVEIRA, V.C.; NAGATA, T.; GUIMARÃES, F. C.; FERREIRA, F. A.; KITAJIMA, E. W.; NICOLINI, C. \& INOUE-NAGATA, A. K. 2013. Characterization of a novel tymovirus on tomato plants in Brazil. Virus genes 46(1): 190-194.

DE SOUSA, D. X. \& LIFSCHITZ, S. 2007. Avaliação do E-value para Execução do BLAST sobre Bases de Dados Fragmentadas. Monografia em Ciências da Computação. Pontifícia Universidade Católica do Rio de Janeiro. Rio de Janeiro, Brasil.

DIANESE, E. C.; RESENDE, R. O. \& INOUE-NAGATA, A. K. 2008. Alta incidência de Pepper yellow mosaic virus em tomateiro em região produtora no Distrito Federal. Tropical Plant Pathology 33: 67-68.

DUARTE, K. M. R.; GOMES, L. H.; ANDRINO, F. G.; LEAL JR, G. A.; SILVA, F. H. B.; PASCHOAL, J. A. R.; GIACOMELli, A. M. B. \& TAVARES, F. C. A. 2002. Identificação do vírus do mosaico do tomateiro (ToMV) tobamovírus, por meio de anticorpos monoclonais. Scientia Agrícola 59: 107-112.

FELSENSTEIN, J. 1985. Confidence limits on phylogenies: An approach using the bootstrap. Evolution 39: 783-791.

FERNANDES, F.R.; ALBUQUERQUE, L.C.; GIORDANO, L.B.; BOITEUX, L.S.; DE ÁVILA, A.C. \& INOUE-NAGATA, A.K. 2008. Diversity and prevalence of brazilian bipartite begomovirus species associated to tomatoes. Virus Genes 36: 251-258.

FERRAND, L.; NOME, C.; ORÍLIO, A. F.; GARCÍA, M. L.; NAGATA, T.; RONCO, L. B. \& DAL BÓ, E. 2016. First report of Tomato blistering mosaic virus infecting tomato in Argentina. Plant Disease 100(5): 1026.

HANSSEN, I. M.; LAPIDOT, M. \& THOMMA, B. P. (2010). Emerging viral diseases of tomato crops. Molecular plant-microbe interactions 23(5): 539-548.

HASEGAWA, M.; KISHINO, H. \& YANO, T. 1985. Dating of the human-ape splitting by a molecular clock of mitochondrial DNA. Journal of Molecular Evolution 22: 160-174.

IACONO, G; HERNANDEZ-LLOPIS, D.; ALFARO-FERNANDEZ, A.; DAVINO, M.; FONT, M.I.; PANNO, S.; GALIPIENSO, L.; RUBIO, L. \& DAVINO, S. 2015. First report of Southern tomato virus in tomato crops in Italy. New disease reports 32: 27.

IBGE. 2016. Levantamento sistemático da produção agrícola: pesquisa mensal da previsão e acompanhamento das safras agrícolas no ano civil. IBGE. 
ftp://ftp.ibge.gov.br/Producao_Agricola/Levantamento_Sistematico_da_Producao_Agri cola_[mensal]/Fasciculo/lspa_201602.pdf. Acesso em 29 de julho de 2016.

INOUE-NAGATA, A. K.; FONSECA, M. E. N.; RESENDE, R. O.; BOITEUX, L. S.; MONTE, D. C.; DUSI, A. N. \& VAN DER VLUGT, R. A. A. 2002. Pepper yellow mosaic virus, a new potyvirus in sweetpepper, Capsicum annuum. Archives of virology 147(4): 849-855.

INOUE-NAGATA, A.K. 2012. Doenças causadas por vírus. In: CLEMENTE, F.M.V.T \& BOITEUX, L.S. Produção de tomate para processamento industrial. Emprapa. Brasília. p. 223-239.

INOUE-NAGATA, A.K. 2013. Doenças viróticas. In: ALVARENGA, M.A.R. Tomate: produção em campo, casa de vegetação e hidroponia. $2^{\mathrm{a}}$ ed. Universidade de Lavras. Lavras. p. 327-344.

KEHOE, M. A.; COUTTS, B. A.; BUIRCHELL, B. J. \& JONES, R. A. C. 2014. Plant Virology and Next generation sequencing: Experiences with a Potyvirus. PLoS ONE 9: e104580.

KITAJIMA, E.W. \& COSTA, A.S. 1969. Association of Pepper ringspot virus (Brazilian Tobacco rattle virus) and host cell mitochondria. Journal of General Virology 4(2): 177181.

KUROZAWA, C. \& PAVAN, M.A. 2005. Doenças do tomateiro. In: KIMATI, H.; AMORIM, L.; REZENDE, J.A.M.; FILHO, A.B. \& CAMARGO, L.E.A. Manual de fitopatologia: doenças das plantas cultivadas. $4^{\mathrm{a}}$ ed. Agronômica Ceres. Piracicaba. p. 642-670.

LIMA, J.A.A.; NASCIMENTO, A.K.Q.; BARBOSA, G.S.; MAIA, L.M.; GOLÇALVES, M.F.B. \& DA SILVA, F.R. 2015. Virologia essencial e viroses em culturas tropicais. Edições UFC. Fortaleza, Ceará.

MACEDO, M.A.; BARRETO, S.S.; HALWASS, M. \& INOUE-NAGATA A.K. 2014. High incidence of Tomato chlorosis virus alone and in mixed infection with begomoviruses in two tomato fields in the Federal Distric and Goiás state, Brazil. Tropical Plant Pathology 39(6): 449-452.

MACFARLANE, S.A. 2010. Tobraviruses: plant pathogens and tools for biotechnology. Molecular plant pathology 11(4): 577-583.

MACIEL-ZAMBOLIM, E.; COSTA, H.; CAPUCHO, A.S.; ÁVILA, A.D.; INOUENAGATA, A.K. \& KITAJIMA, E.W. 2004. Surto epidemiológico do vírus do mosaico amarelo do pimentão em tomateiro na região serrana do Espírito Santo. Fitopatologia 
Brasileira 29(3): 325-327.

MAKISHIMA, N. 2011. O tomateiro - 50 anos da Associação Brasileira de Horticultura. In: $51^{\circ}$ CONGRESSO BRASILEIRO DE OLERICULTURA. Viçosa, MG. Julho de 2011. Associação Brasileiro de Horticultura, Vitória da Conquista, Bahia. p. 5969-5975.

MELGAREJO, T.A.; KON, T.; ROJAS, M.R.; PAZ-CARRASCO, L.; ZERBINI, F.M. \& GILBERTSON, R.L. 2013. Characterization of a New World Monopartite Begomovirus Causing Leaf Curl Disease of Tomato in Ecuador and Peru Reveals a New Direction in Geminivirus Evolution. Journal of Virology 87(10): 5397-5413.

METZKER, M.L. 2010. Sequencing technologies - the next generation. Nature Reviews Genetics 11: 31-46.

MUHIRE, B.M.; VARSANI, A. \& MARTIN, D.P. 2014. SDT: a virus classification tool based on pairwise sequence alignment and identity calculation. PloS one 9(9): e108277.

NAGAI, H. 1983. Melhoramento do pimentão (Capsicum annuum L.) visando resistência ao vírus Y. Horticultura Brasileira 1: 3-9.

NAGATA, T.; ALMEIDA, A.C.L.; RESENDE, R.D.O. \& DE AVILA, A.C. 2004. The competence of four thrips species to transmit and replicate four tospoviruses. Plant Pathology 53(2): 136-140.

NAGATA, T.; DE ÁVILA, A.C.; TAVARES, P.; BARBOSA, C.; JULIATTI, F. \& KITAJIMA, E.W.1995. Occurence of different Tospovírus in six states of Brazil. Fitopatologia Brasileira 20: 90-95.

NAGATA, T.; RESENDE, R.D.O.; KITAJIMA, E.W.; COSTA, H.; INOUE-NAGATA, A.K. \& DE ÁVILA, A.C. 1998. First report of natural occurrence of Zucchini lethal chlorosis tospovirus on cucumber and Chrysanthemum stem necrosis tospovirus on tomato in Brazil. Plant Disease 82(12): 1403-1403.

NOGUEIRA, L.; VIEIRA, B.G.; PEREIRA-CARVALHO, R.C.; DIANESE, E.C.; RESENDE, R.O.; BOITEUX, L.S. \& FONSECA, M.E.N. 2011. Detecção de Tomato chlorosis virus (Crinivirus, Closterovidae) em tomateiro no Distrito Federal. In: Anais XLIV CONGRESSO BRASILEIRO DE FITOPATOLOGIA. Bento Gonçalvez, RS. Agosto de 2011. Sociedade Brasileira de Fitopatologia. Brasília, DF. p. 1414.

OKA, N.; OHKI, T.; HONDA, Y.; NAGAOKA, K. \& TAKENAKA, M. 2008. Inhibition of Pepper mild mottle virus with commercial cellulases. Journal of phytopathology 156(2): 65-67.

PADMANABHAN, C.; ZHENG, Y.; LI, R.; FEI, Z. \& LING, K. 2015b. Complete genome sequence of Southern tomato virus naturally infecting tomatoes in Bangladesh. Genome 
Announcements 3(6): e01522-15.

PADMANABHAN, C.; ZHENG, Y.; LI, R.; SUN, S.; ZHANG, D.; LIU, Y.; FEI, Z. \& LING, K. 2015. Complete genome sequence of Southern tomato virus identified in China using next generation sequencing. Genome Announcements 3(5): e01226-15.

QUAN, P. L.; BRIESE, T.; PALACIOS, G. \& LIPKIN, W. I. 2008. Rapid sequence-based diagnosis of viral infection. Antiviral research 79(1): 1-5.

QUEZADO-DUVAL A.M.; INOUE-NAGATA, A.K.; REIS, A.; PINHEIRO, J.B.; LOPES, C.A.; ARAÚJO, E.R.; FONTENELLE, M.R.; COSTA, J.R.; GUIMARÃES, C.M.N.; ROSSATO, M.; BECKER, W.F.; COSTA, H.; FERREIRA, M.A.S.V. \& DESTÉFANO, S.A.L. 2013. Levantamento de doenças e mosca-branca em tomateiro em regiões produtoras no Brasil. Concórdia: Embrapa Hortaliças, Brasília - DF, 36 p. (Boletim de Pesquisa e Desenvolvimento, 100).

QUEZADO-DUVAL, A.M.; NASCIMENTO, A.R.; PONTES, N.C.; MOITA, A.W.; ASSUNÇÃO, A.; GOLYNSKI, A.; INOUE-NAGATA, A.K.; OLIVEIRA, R.T.; CASTRO, Y.O. \& MELO, B.J. 2014. Desempenho de híbridos de tomate para processamento industrial em pressão de begomovirose e de manchabacteriana. Horticultura Brasileira 32: 446-452.

RADFORD, A.D.; CHAPMAN, D.; DIXON, L.; CHANTREY, J.; DARBY, A.C. \& HALL, N. 2012. Application of next generation sequencing technologies in virology. Journal of General Virology 93: 1853-68.

RÊGO, C.M. 2016. Diversidade genômica de begomovírus em tomateiros resistente (BRS SENA) e susceptível (H-9553). Dissertação de Mestrado. Universidade de Brasília, Brasília, Brasil.

RESENDE, R.D.O.; POZZER, L.; NAGATA, T.; BEZERRA, I.C.; LIMA, M.I.; DE BRITO GIORDANO, L. \& DE ÁVILA, A.C. 1996. New tospoviruses found in Brazil. Tospoviruses and Thrips of Floral and Vegetable Crops. 431: 78-89.

RIBEIRO, S.G.; AMBROZEVICIUS, L.P.; DE ÁVILA, A.C.; BEZERRA, I.C.; CALEGARIO, R.F.; FERNANDES, J.J.; LIMA, M.F.; DE MELLO, R.N.; ROCHA, H. \& ZERBINI, F.M. 2003. Distribution and genetic diversity of tomato-infecting begomoviruses in Brazil. Archives of Virology 148(2): 281-295.

RODRIGUES, K.B.; ORÍlIO, A.F.; BLAWID, R.; MELO, F.L. \& NAGATA, T. 2015. Subcellular localization of $\mathrm{p} 29$, a putative movement protein of Pepper ringspot virus. Archives of virology 160(1): 359-364.

SABANADZOVIC, S.; VALVERDE, R.A.; BROWN, J.K.; MARTIN, R.R.; TZANETAKIS, 
I.E. 2009. Southern tomato virus: the link between the families Totiviridae and Partitiviridae. Virus Research 140: 130-137.

SANCHES, M.M. \& KRAUSE-SAKATE, R. 2013. Análises para vírus, viroides e fitoplasmas em material vegetal importado. Concórdia: Embrapa Recursos Genéticos e Biotecnologia, Brasília - DF, 31 p. (Documentos, 344).

SILVA, O.D.A.; FIGUEIRA, A.D.R.; BOARI, A.D.J.; PINTO, C.A.B.P. \& BONI, R.R. 2005. Biological characterization of the PVX isolates (Potato virus X) from Brazil. Ciência e Agrotecnologia 29(3): 521-527.

STANLEY, J.; BISARO, D.M.; BRIDDON, R.W.; BROWN, J.K.; FAUQUET, C.M.; HARRISON, B.D.; RYBICKI, E.P. \& STENGER, D.C. 2005. Family Geminiviridae. In: FAUQUET, C. M.; MAYO, A.; MANILOFF, J.; DESSELBERGER, U.; BALL, L. A. Virus Taxonomy: VIIIth Report of the International Committee on Taxonomy of Viruses. Elsevier/Academic Press. London. p. 789-792.

TZANETAKIS, I.E. \& SABANADZOVIC, S. 2013. Establishment of the family Amalgaviridae, the genus Amalgavirus and inclusion of four species in the genus. ICTV. http://www.ictvonline.org/proposals/2013.005a-gP.A.v2.Amalgaviridae.pdf. Acesso em 25 de junho de 2016.

UNTIVEROS, M.; PEREZ-EGUSQUIZA, Z. \& CLOVER, G. 2010. PCR assays for the detection of members of the genus Ilarvirus and family Bromoviridae. Journal of virological methods 165(1): 97-104.

VERBEEK, M.; DULlEMANS, A.M.; ESPINO, A.; BOTELlA, M.; ALFAROFERNÁNDEZ, A. \& FONT, M.I. 2015. First report of Southern tomato virus in tomato in the Canary Islands, Spain. J Plant Pathol 97:392.

WANG, Z.; GERSTEIN, M. \& SNYDER, M. 2009. RNA-Seq: A revolutionary tool for transcriptomics. Nature Reviews Genetics 10: 57-63.

WU, Q.; DING, S.; ZHANG, Y \& ZHU, S. 2015. Identification of viruses and viroids by next generation sequencing and homology-dependent and homology-independent algorithms. Annual Review of Phytopathology 53: 425-444.

ZERBINO, D.R. \& BIRNEY, E. 2008. Velvet: Algorithms for de novo short read assembly using de Bruijn graphs. Genome Research 18(5): 821-829.

ZHANG, H.; GAO, S.; LERCHER, M.J.; HU, S. \& CHEN, W.H. 2012. Evolview, an online tool for visualizing, annotating and managing phylogenetic trees. Nucleic acids research 40(1): 569-572. 


\section{CAPÍTULO 3}

\section{Análise do Southern tomato virus (STV) detectado no Brasil}

\section{RESUMO}

As doenças virais representam um grande desafio para produtores de tomate. Não estão disponíveis no mercado produtos químicos que restabeleçam a sanidade da planta após uma infecção viral, logo, as estratégias de controle mais efetivas são baseadas no princípio da exclusão, com a prevenção da entrada do vírus na lavoura. As medidas de controle baseadas nesse princípio são basicamente praticadas através de medidas quarentenárias. No Brasil, o Ministério da Agricultura, Pecúaria e Abastecimento é responsável por regulamentar a importação de diferentes espécies vegetais, porém as facilidades dos meios de transporte modernos e o aumento do trânsito e intercâmbio internacional tornam as medidas de exclusão utilizadas cada vez mais vulneráveis. A preocupação com a entrada de patógenos no país levou à regulamentação da importação de sementes e mudas, através de uma instrução normativa que estabeleceu a prévia avaliação da veiculação de pragas nos materiais importados. Após a análise da população viral presente em tomateiros de Araguari, MG, Campinas, SP, e Brazlândia, DF, por sequenciamento de alto desempenho, o vírus Southern tomato virus (STV), não relatado no Brasil, foi detectado em todas as bibliotecas (BRAZ, AHOL, TOCA1, TOCA2 e CAM-RNY2). Dois genomas parciais foram obtidos através da utilização de ferramentas de bioinformática: STV DF e STV MG. O STV é um amalgavírus capaz de ser transmitido por sementes a taxas elevadas, que variam de acordo com a cultivar. Nos últimos anos, os relatos desse vírus têm aumentado em diversos países, porém sua presença em plantas assintomáticas, ausência em plantas sintomáticas e a constante diagnose em co-infecção com outros vírus dificultam o estudo de sua sintomatologia e os efeitos de sua presença em lotes comerciais de diversas variedades de tomateiros ainda são desconhecidos. Com o objetivo de analisar o STV encontrado no Brasil, estudos filogenéticos foram conduzidos e levantamentos de sua presença foram realizados em plantas coletadas no campo e em plântulas de sementes comercializadas de tomateiro. Inicialmente, o vírus foi detectado nas amostras originais analisadas por NGS (BRAZ, AHOL, TOCA1, TOCA2) por RT-PCR. $\mathrm{Na}$ análise filogenética realizada pelo método da máxima verossimilhança, os genomas semicompletos de Brazlândia e Araguari agruparam-se com outras sequências de STV disponíveis em bancos de dados, confirmando alta proximidade com vários desses isolados provenientes de outros locais do mundo. O agrupamento formado pelos isolados de STV e outros membros 
da família Amalgaviridae mostrou-se mais próximo dos vírus da família Partitiviridae que do vírus pertencente à família Totiviridae, apesar da semelhança na organização genômica entre os totivírus e os amalgavírus. O STV também foi detectado em amostras de plantas de tomateiros coletadas em Brazlândia, São José do Rio Preto, Morrinhos, Taquara, Goianápolis, Corumbá de Goiás e Paraná, A incidência variou de $23 \%$ nas nove amostras provenientes de São José do Rio Preto, a 100\% nas três amostras coletadas em Morrinhos. O vírus foi detectado em plântulas recém-germinadas das cultivares: H-9553, Santa Clara, H-9992 e Predador, com incidência que variou de 9\% na cultivar H-9553 a 100\% na cultivar Predador. A detecção em plantas coletadas em diversos campos de produção de tomate e em plântulas de sementes comerciais sugere sua extensa distribuição nas lavouras do país e em sementes comerciais comumente utilizadas pelo produtor. A análise filogenética demonstrando alta proximidade com isolados de outros países confirma a provável introdução desse vírus no Brasil através de material importado. Apesar da existência de normas que exijam a realização de análise de risco de pragas (ARP), a grande quantidade de importadores interessados levou o governo a liberar, em 2005, a importação de produtos que já foram importados pelo menos uma vez desde 12 de agosto de 1997, sem a necessidade do cumprimento da ARP. A espécie Solanum lycopersicum é a que possui mais origens autorizadas: quatorze países exportam sementes de tomate para o Brasil sem ARP. Embora essa ampla distribuição de STV não pareça ser alarmante por conta da provável ausência de sintomas e de mecanismos de transmissão horizontal que possam levar a evolução de estirpes virais patogênicas, a fragilidade a qual está submetido o controle do material vegetal importado pelo país fica em evidência. Algumas espécies virais transmitidas verticalmente em tomateiro estão presentes em países autorizados a exportar sementes para o Brasil sem a realização da ARP, logo, embora a importação de sementes seja essencial para a economia brasileira, a não realização de medidas fitossanitárias que avaliem esses materiais pode trazer consequências desastrosas para a agricultura brasileira.

Palavras-chave: quarentena, sementes, STV, sequenciamento de alto desempenho, tomateiro. 


\section{Southern tomato virus (STV) in Brazil}

\section{ABSTRACT}

Viral diseases are a big challenge for the tomato growers. There are no commercially available products that restore the sanity of a plant after a viral infection, Therefore the most effective control strategies are based on the principle of exclusion. The control measures based on this principle are fundamentally implemented through quarantine procedures. In Brazil, the Ministry of Agriculture is responsible for regulating the import of different plant species, but the facility brought by the modern transportation system and heavy international traffic transformed the control by exclusion a vulnerable process. The concerns on the entry of pathogens into the country have led to the establishment of a regulation of the import of seeds and seedlings through a normative instruction requiring a previous evaluation on the presence of pests in the imported materials. In this study, after analyzing the viral population present in tomato plants from Araguari, MG, Campinas, SP, and Brazlândia, DF, by NGS, the virus Southern tomato virus (STV), not reported in Brazil, was detected in all libraries (BRAZ, AHOL, TOCA1, TOCA2 and CAM-RNY2). Two semi-complete genomes were obtained through the use of bioinformatics tools: STV-DF and STV-MG. STV is an amalgavírus that can be transmitted by seed at high rates, varying according to the plant cultivar. In the last years, reports of this virus have increased in many countries, but their presence in asymptomatic plants and the constant detection in co-infection with other viruses made the study on symptoms difficult to be implemented. With the aim to analyze the STV isolates found in Brazil, phylogenetic studies were conducted and surveys of their presence on tomato plants collected in the field and tomato seedlings of commercialized seeds were performed. Initially, the virus was detected in the following original samples analyzed by NGS using RTPCR: BRAZ, AHOL, TOCA1, TOCA2. In a phylogenetic study performed by the maximum likelihood method, the STV sequences of Brazlândia and Araguari clustered with other STV sequences available in databases, which confirmed the close relationship with several of these isolates from other locations in the world. The grouping formed by the STV isolates and other members of Amalgaviridae family has shown that they are closer to the viruses of family Partitiviridae than to the viruses of Totiviridae, despite the similarity in the genomic organization of totivíruses and amalgavíruses. STV-specific fragments were detected in tomato plants collected in Brazlândia, São José do Rio Preto, Morrinhos, Taquara, Goianápolis, Corumbá de Goiás and Paraná. The incidence ranged from $23 \%$ in nine samples 
from São José do Rio Preto to $100 \%$ in the the samples collected in Morrinhos. The virus was detected in newly germinated seedlings of cultivars: H-9553, Santa Clara, H-9992 and Predator, with an incidence ranging from $9 \%$ in $\mathrm{H}-9553$ to $100 \%$ in Predator. The detection of STV in tomato plants from several production fields and seedlings of commercial seeds demonstrated its extensive distribution in the tomato crop of the country and in commercial seeds commonly planted by the grower. The phylogenetic study that showed a high proximity with isolates from other countries confirms the possible introduction of this virus in Brazil by imported material. Despite the rules requiring a pest risk analysis (PRA), in 2005, a large number of importers were authorized from the government to import products that have already been imported at least once since August 12, 1997, without requiring the PRA. Solanum lycopersicum is the plant species with the highest release rate: fourteen countries export tomato seeds to Brazil without PRA. Although this broad distribution of STV does not seem to be alarming, due the probable lack of symptoms and absence of horizontal transmission mechanisms that can lead to evolution of pathogenic viral strains, the fragile system on the control of plant material imports by the country became evident. Some vertically transmitted viral species in tomato were already reported in countries that export seeds to Brazil without the requirement of PRA. It means that although seed importation is likely essential for the Brazilian tomato production chain, the failure on the conduction of an appropriate phytosanitary control system to evaluate the sanity of the materials can bring disastrous consequences for the Brazilian agriculture.

Key-words: quarentine, seeds, STV, next generation sequencing, tomato. 


\section{INTRODUÇÃO}

Após a análise da população viral presente em tomateiros de Campinas-SP, AraguariMG e Brazlândia-DF, o vírus Southern tomato virus (STV), nunca relatado no Brasil, foi detectado em todas as amostras testadas e dois genomas parciais foram obtidos através da utilização de ferramentas de bioinformática (Capítulo 2).

O STV não é transmitido por enxertia ou mecanicamente, porém as taxas de transmissão vertical são elevadas, a depender da variedade testada (Sabanadzovic et al., 2009). Esse vírus foi descrito em 2009 na América do Norte (isolados dos Estados Unidos e do México), com suspeitas de associação com uma nova desordem no tomateiro (Sabanadzovic et al., 2009).

STV pertence à família Amalgaviridae e ao gênero Amalgavírus, estabelecidos em 2011 para abrigar as espécies Blueberry latent virus, Rhododendron virus A, Vicia cryptic virus $\mathrm{M}$ e Southern tomato virus (Tzanetakis \& Sabanadzovic, 2013). Seu genoma consiste em um RNA fita dupla (dsRNA) de aproximadamente 3,5 Kbp, composto de duas fases de leitura abertas (ORFs) sobrepostas que codificam a capa proteica (CP) e a RNA polimerase (RdRp) (Sabanadzovic et al., 2009).

Os amalgavírus possuem organização genômica semelhante a dos vírus da família Totiviridae, composta por único segmento contendo duas ORFs sobrepostas parcialmente, com o mesmo mecanismo de expressão da RNA polimerase (frameshifting ribossomal) (Tzanetakis \& Sabanadzovic, 2013). Filogeneticamente, o gênero Amalgavirus encontra-se mais próximo à família Partitiviridae, apesar desta incluir vírus de RNA fita dupla composto por dois segmentos, que codificam a RNA polimerase (dsRNA1) e a proteína de revestimento (dsRNA2) (Sabanadzovic et al., 2009; Sabanadzovic et al., 2010; Ghabrial et al., 2011; Martin et al., 2011). 
Nos últimos anos, os relatos desse vírus têm aumentado, sendo sua detecção em tomateiros relatada na França (Candresse et al., 2013), na Espanha (Verbeek et al., 2012), na China (Padmanabhan et al., 2015), em Bangladesh (Padmanabhan et al., 2015b) e na Itália (Iacono et al., 2015).

Amostras de plantas sintomáticas negativas em testes de detecção de STV e a ausência de sintomas em plantas infectadas causaram dúvidas a respeito de sua patogenicidade (Sabanadzovic et al., 2009). A alta taxa de transmissão vertical sugere que a sua distribuição pode ser mais ampla do que é atualmente conhecida (Candresse et al., 2013). Tal distribuição mais ampla gerou preocupações para a indústria do tomate (Sabanadzovic et al., 2009; Candresse et al., 2013).

A detecção em co-infecção com outros vírus dificulta o estudo de sua sintomatologia e os efeitos de sua presença em lotes de sementes comerciais de diversas variedades (Sabanadzovic et al., 2009). Estudos que visem a caracterização de suas propriedades biológicas e moleculares são necessários para uma resposta final e conclusiva quanto ao seu potencial de patogenicidade (Iacono et al., 2015).

Com o objetivo de analisar o isolado de STV encontrado no Brasil, estudos filogenéticos foram conduzidos. Além disso, plantas coletadas no campo e plântulas de sementes comerciais de tomateiro foram testadas para o vírus.

\section{MATERIAL E MÉTODOS}

\section{Coleta}

As amostras originais das bibliotecas BRAZ, AHOL, TOCA1 e TOCA2 foram utilizadas para detecção por RT-PCR com os pares de primers STV3 e STVm, descritos à frente. Em março de 2016 foi realizada coleta de amostras de tomateiro na chácara Belmonte em Brazlândia para avaliar a incidência do STV na região. Foram coletadas aleatoriamente 20 amostras de plantas assintomáticas da cultivar BRS Zamir e 20 da cultivar Serato. 
Testes adicionais de detecção de STV foram realizados em amostras coletadas em 2015: 14 amostras coletadas em Patos de Minas, MG; 24 em Taquara, DF, das cultivares Trucker (9), Júpiter (6) e Marguerita (9); seis em Corumbá de Goiás, oito em Goianápolis e três em Morrinhos, no estado de GO; nove das cultivares cultivar Ravena (4) e Tyna (5) em São José do Rio Preto, em São Paulo; e 23 amostras em Reserva, no estado de Paraná.

\section{Análise filogenética da sequência genômica de Southern tomato virus}

As duas novas sequências STV-DF e STV-MG (Capítulo 2), com 3.418 e 3.403 nucleotídeos respectivamente, foram analisadas com a ferramenta ORF Finder (NCBI) para a identificação das fases de leitura em potencial. Posteriormente, as sequências de nucleotídeos da RNA polimerase (RdRp) foram alinhadas com as sequências de outros isolados utilizando o método Muscle no programa Mega 7 (Kumar et al., 2016). Para esse alinhamento foram utilizadas todas as sequências de STV do banco de dados: México (NC_011591); Bangladesh (KT634055); Carolina do Norte (KT852573); Mississipi (EU413670); China (KT438549); isolados de outros amalgavírus conhecidos: Blueberry latent vírus - BILV (NC_014593) e Rhododendron virus A - RhVA (NC_014481); isolados de espécies pertencentes à família Partitiviridae: White clover cryptic virus 1 - WCCV-1 (NC_006275), Rose cryptic virus 1 RCV-1 (NC_010346), Vicia cryptic virus - VCV (NC_007241) e Fig cryptic virus - FCV (NC_015494); e um isolado pertencente à família Totiviridae: Giardia lamblia virus - GLV (NC_003555).

A partir do alinhamento foi realizada análise filogenética através do método da máximaverossimilhança baseado em modelo de substituição escolhido de acordo com o valor do critério de informação de akaike (AIC). A árvore filogenética inicial para a busca heurística foi obtida pela aplicação do método de Neighbor-Joining, com 4.000 repetições de bootstrap (Felsenstein, 1985) no programa Mega 7. 


\section{Germinação de plântulas de tomateiro}

Sementes comerciais das cultivares BRS Sena, Predador, Santa Clara, H-9992, H-9553 foram germinadas sob papel filtro umedecido com água destilada colocado em recipiente plástico transparente. Com aproximadamente 10 dias foi feita a extração do RNA das plântulas, utilizando o método Trizol (Invitrogen). Foi extraído RNA de uma planta sadia de tomateiro cv. Santa Clara, que foi utilizado como controle negativo.

A detecção do STV nessas plântulas foi realizada por meio de RT-PCR, utilizando o par de primers STVm, descritos à frente.

\section{Extração de RNA}

A extração de RNA foi realizada utilizando Trizol (Invitrogen). Aproximadamente 100 mg de material foliar foram macerados dentro de um microtubo de 1,5 mL com o auxílio de pistilo e imediatamente foi adicionado $1 \mathrm{~mL}$ de Trizol. Após cinco minutos de incubação a temperatura ambiente, foram acrescentados $200 \mu \mathrm{L}$ de clorofórmio. Posteriormente o macerado foi vortexado por 30 segundos e foi realizada centrifugação em centrífuga refrigerada a $4{ }^{\circ} \mathrm{C}$ por 15 minutos a $12.000 \mathrm{rpm}$.

Após a centrifugação, cerca de $500 \mu \mathrm{L}$ de sobrenadante foram retirados por pipetagem e transferidos para um novo tubo contendo $250 \mu \mathrm{L}$ de cloreto de sódio $1,2 \mathrm{M}$ e $250 \mu \mathrm{L}$ de isopropanol. O tubo foi vertido cinco vezes para homogeneização, incubado por 10 minutos a temperatura ambiente e centrifugado novamente a $12.000 \mathrm{rpm}$ por 10 minutos para a formação do pellet. O sobrenadante foi descartado e adicionou-se $1 \mathrm{~mL}$ de etanol $75 \%$ gelado para a lavagem do pellet. $O$ tubo foi submetido a nova centrifugação por 5 minutos a 10.000 rpm, o sobrenadante foi novamente descartado e o tubo permaneceu aberto por até uma hora (sob observação) para a secagem do pellet. Após a secagem foram adicionados $40 \mu \mathrm{L}$ de água Milli-Q tratada com DEPC, seguida de incubação por 15 minutos a $55{ }^{\circ} \mathrm{C}$ para a ressuspensão do pellet. O RNA total foi armazenado em frezzer $-80{ }^{\circ} \mathrm{C}$ para posterior utilização. 


\section{RT-PCR}

Foram utilizados dois pares de primers iniciadores: STVm-F (AAGGAGATG ACCCCTTGCAG) e STVm-R (ACCTTACGGACTCCCACCTC), desenhado a partir da sequência obtida no sequenciamento de alto desempenho; e STV3-F (CGTTATCTTAGG CGTCAGCT) e STV3-R (GGAGTTTGATTGCATCAGCG) (Sabanadzovic et al., 2009). Ambos os pares amplificam região de sobreposição entre os genes da capa proteica e da RNA polimerase do vírus, resultando em fragmentos de 240 e 440 pares de bases, respectivamente Coréia do Sul), para confirmar a amplificação do genoma de STV.

Tabela 4).

Para a obtenção do cDNA, $1 \mu \mathrm{L}$ do RNA extraído foi adicionado a uma reação contendo 4,5 $\mu \mathrm{L}$ de água milli-Q; $0,1 \mu \mathrm{L}$ do oligonucleotídeo iniciador a $10 \mu \mathrm{M}$ e $0,1 \mu \mathrm{L}$ de desoxinucleotídeos trifosfato $2,5 \mathrm{mM}(\mathrm{dNTP})$. A reação foi aquecida a $94^{\circ} \mathrm{C}$ por 10 minutos para desnaturação do RNA dupla fita e imediatamente colocada em gelo. Em seguida foram adicionados $0,5 \mu \mathrm{L}$ de DTT $(0,1 \mathrm{M}) ; 2 \mu \mathrm{L}$ de tampão First Strand M-MLV 5x;0,5 $\mu \mathrm{L}$ da enzima transcriptase reversa M-MLV (200U/ $\mu \mathrm{L}$, Invitrogen) e $0,5 \mu \mathrm{L}$ de RNaseOUT (40 $\mathrm{U} / \mu \mathrm{L}$, Invitrogen). A reação foi incubada a $37^{\circ} \mathrm{C}$ por 50 minutos e a $70^{\circ} \mathrm{C}$ por 15 minutos.

O cDNA sintetizado foi utilizado na reação em cadeia da polimerase (PCR) utilizando: $1 \mu \mathrm{L}$ de tampão 10x (Invitrogen); 0,8 $\mu \mathrm{L}$ de cloreto de magnésio (50 mM - Invitrogen); 2,5 $\mu \mathrm{L}$ de dNTP's $(2,5 \mathrm{mM}) ; 0,1 \mu \mathrm{L}$ de cada primer a $10 \mu \mathrm{M} ; 0,1 \mu \mathrm{L}$ da enzima Taq DNA polymerase (5U/ $\mu \mathrm{L}$ - Invitrogen), $1 \mu \mathrm{L}$ de cDNA e $6,5 \mu \mathrm{L}$ de água milli-Q, completando o volume da reação para $10 \mu \mathrm{L}$. A reação foi então submetida ao seguinte programa em termociclador: $94^{\circ} \mathrm{C}$ por 2 minutos; 40 ciclos a $94^{\circ} \mathrm{C}$ por 30 segundos; $53^{\circ} \mathrm{C}$ por 30 segundos (com primers $\mathrm{STV} 3$ ) ou $50^{\circ} \mathrm{C}$ por 30 segundos (com primers $\mathrm{STVm}$ ) e $72^{\circ} \mathrm{C}$ por 45 segundos; e $72^{\circ} \mathrm{C}$ por 10 minutos. A reação foi então submetida ao seguinte programa em 
termociclador: $94^{\circ} \mathrm{C}$ por 2 minutos; 40 ciclos a $94^{\circ} \mathrm{C}$ por 30 segundos, $53^{\circ} \mathrm{C}$ por 30 segundos e $72^{\circ} \mathrm{C}$ por 45 segundos; e com $72^{\circ} \mathrm{C}$ por 10 minutos.

O produto amplificado aplicado em gel de agarose 1\%, corado com brometo de etídeo e visualizado sob luz ultravioleta. Os fragmentos gerados partir da RT-PCR com a amostra original BRAZ utilizando os dois pares de primers foram purificados utilizando o kit Invisorb Fragment CleanUp (Stratec Molecular) e enviados para sequenciamento pelo método de Sanger na Macrogen (Coréia do Sul), para confirmar a amplificação do genoma de STV.

Tabela 4: Oligonucleotídeos iniciadores (primers) utilizados para a detecção de Southern tomato virus (STV) em plântulas de diferentes cultivares de tomateiro e em amostras de plantas coletadas em campo.

\begin{tabular}{ccccc}
\hline $\begin{array}{c}\text { Nome do } \\
\text { par }\end{array}$ & Primers & Sequência & $\begin{array}{c}\text { Tamanho do } \\
\text { fragmento } \\
\text { (bp.) }\end{array}$ & Referência \\
\hline STV3 & $\begin{array}{c}\text { STV3-F } \\
\text { STV3-R }\end{array}$ & $\begin{array}{c}\text { CGTTATCTTAGGCGTCAGCT } \\
\text { GGAGTTTGATTGCATCAGCG }\end{array}$ & 440 & $\begin{array}{c}\text { Sabanadzovic } \\
\text { et al., 2009 }\end{array}$ \\
\hline \multirow{2}{*}{ STVm } & $\begin{array}{c}\text { STVm-F } \\
\text { STVm-R }\end{array}$ & $\begin{array}{c}\text { AAGGAGATGACCCCTTGCAG } \\
\text { ACCTTACGGACTCCCACCTC }\end{array}$ & 240 & - ----- \\
\hline
\end{tabular}

\section{RESULTADOS}

Após a detecção de STV nas amostras enviadas para sequenciamento de alto desempenho (Capítulo 2), inicialmente os pares de primers STV3 e STVm foram utilizados para a detecção do vírus nas amostras originais enviadas para sequenciamento (alíquotas de RNA de cada amostra retiradas antes do envio para a Macrogen e guardadas a $-80^{\circ} \mathrm{C}$ ). As amostras testadas foram BRAZ, AHOL, TOCA1 e TOCA2. Todas as amostras testadas apresentaram amplificação de fragmento por RT-PCR conforme tamanho esperado (Figura $11)$. 

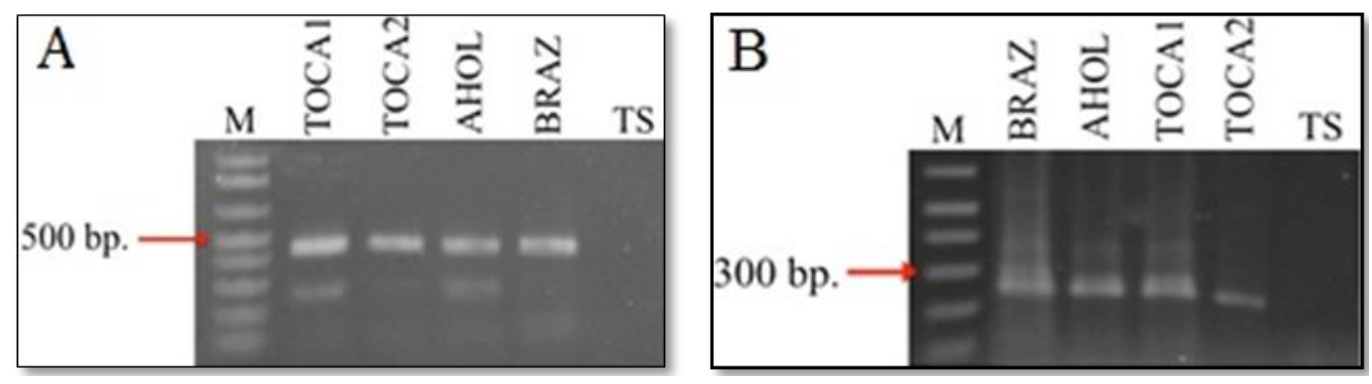

Figura 11: (A) Gel de agarose a 1\% mostrando fragmento de 440 pares de bases amplificado por RT-PCR utilizando os primers STV3-F e STV3-R com as amotras originais das bibliotecas TOCA1, TOCA2, AHOL e BRAZ e o tomateiro sadio (TS) como controle negativo; (B) Gel de agarose a 1\% mostrando fragmento de 240 pares de bases amplificado a partir de RT-PCR utilizando primers STVm-F e STVm-R nas mesmas bibliotecas. $\mathrm{M}=1 \mathrm{~kb}$ plus (Invitrogen).

A análise blast das sequências obtidas por sequenciamento dos fragmentos amplificados a partir da amostra BRAZ com os dois pares de primers contra o banco de dados confirmou a amplificação do genoma de STV.

\section{Análise filogenética do genoma de STV}

Para avaliar a relação filogenética entre os isolados de STV brasileiros e de outros descritos no mundo, as duas sequências genômicas obtidas por sequenciamento de alto desempenho de amostras de Brazlândia e Minas (capítulo 2) foram utilizadas para análise filogenética. Foi utilizado o método da máxima verossimilhança, baseado no modelo de Tâmura 3 parâmetros. A árvore de maior probabilidade foi desenhada em escala, com o comprimento dos ramos medidos de acordo com o número de substituições por sítio (Figura 12). 


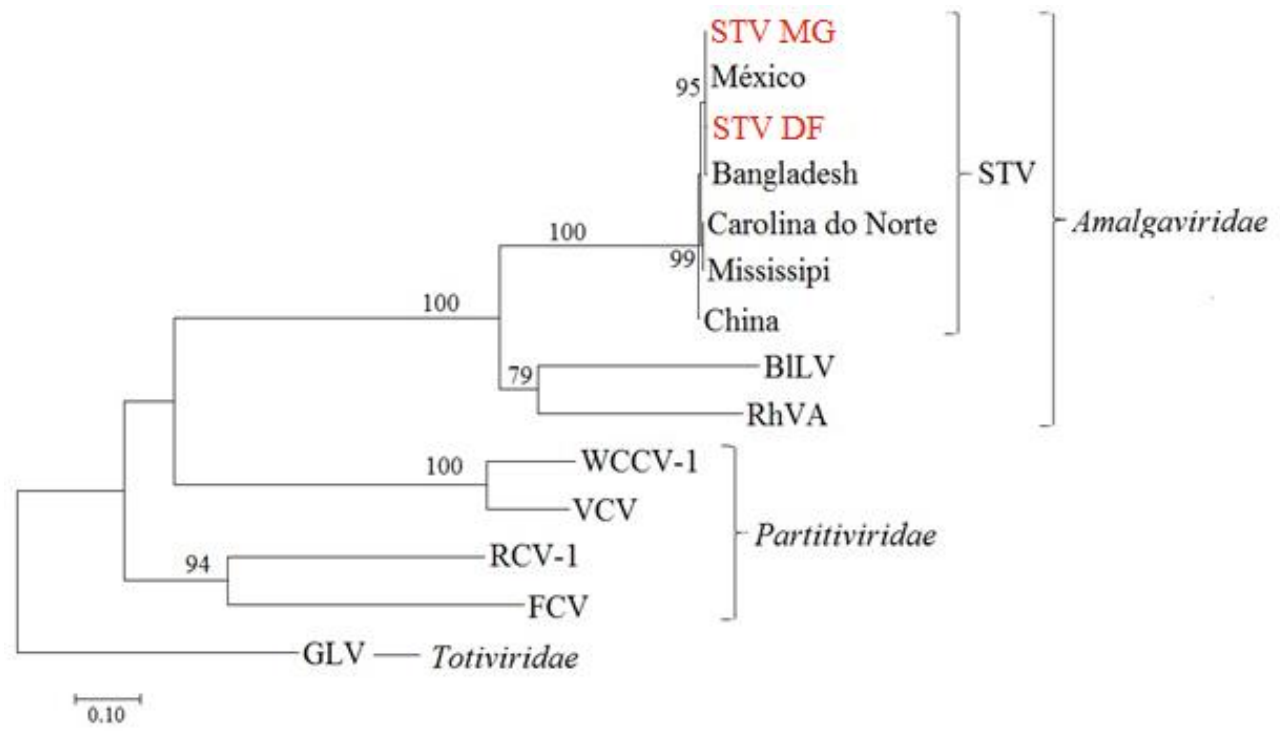

Figura 12: Árvore filogenética obtida pelo método da máxima verossimilhança. A análise envolveu sequências de nucleotídeos da RNA polimerase de quatorze isolados: STV-DF e STV MG (em vermelho); México (NC_011591); Bangladesh (KT634055); Carolina do Norte (KT852573); Mississipi (EU413670); China (KT438549); Blueberry latent vírus - BlLV (NC_014593); Rhododendron virus A - RhVA (NC_014481); White clover cryptic virus 1 WCCV-1 (NC_006275), Rose cryptic virus 1 - RCV-1 (NC_010346), Vicia cryptic virus VCV (NC_007241); Fig cryptic virus - FCV (NC_015494) e Giardia lamblia virus - GLV (NC_003555). A barra indica número de substituições por sítio.

$\mathrm{Na}$ análise filogenética da RNA polimerase (RdRp), os isolados de Brazlândia (STVDF) e de Minas Gerais (STV-MG) formaram um agrupamento com os outros isolados de STV do banco de dados, demonstrando uma grande proximidade entre eles. Esse agrupamento também se mostrou próximo a outros vírus pertencentes à família Amalgaviridae (BILV e RhVA). Observou-se também que o grupo dos amalgavírus mostrou maior proximidade com os vírus da família Partitiviridae (WCCV-1, VCV, RCV-1 e FCV) que com os vírus pertencentes à família Totiviridae (GLV) (Figura 12).

\section{Detecção em amostras do campo}

A detecção nas amostras de campo foi realizada para verificar a distribuição desse vírus nos campos de produção de tomate em algumas regiões do Brasil. 
O RNA de um tomateiro sadio e água Milli-Q tratada com DEPC foram utilizados como controle negativo e o clone p-GEM-T Easy-STV 440 DF, descrito no Capítulo 2, foi utilizado como controle positivo.

O STV foi detectado em amostras de plantas coletadas em Brazlândia, Patos de Minas, São José do Rio Preto, Morrinhos, Taquara, Goianápolis, Corumbá de Goiás e Paraná utilizando o par de primers STV3. Dentre as amostras de Brazlândia, todas as amostras da cultivar Serato e dezenove das vinte amostras testadas da cultivar BRS Zamir estavam infectadas (Figura 13). A incidência do STV foi de 98\% na lavoura de Brazlândia (Tabela 5). Não houve amplificação nos controles negativos.

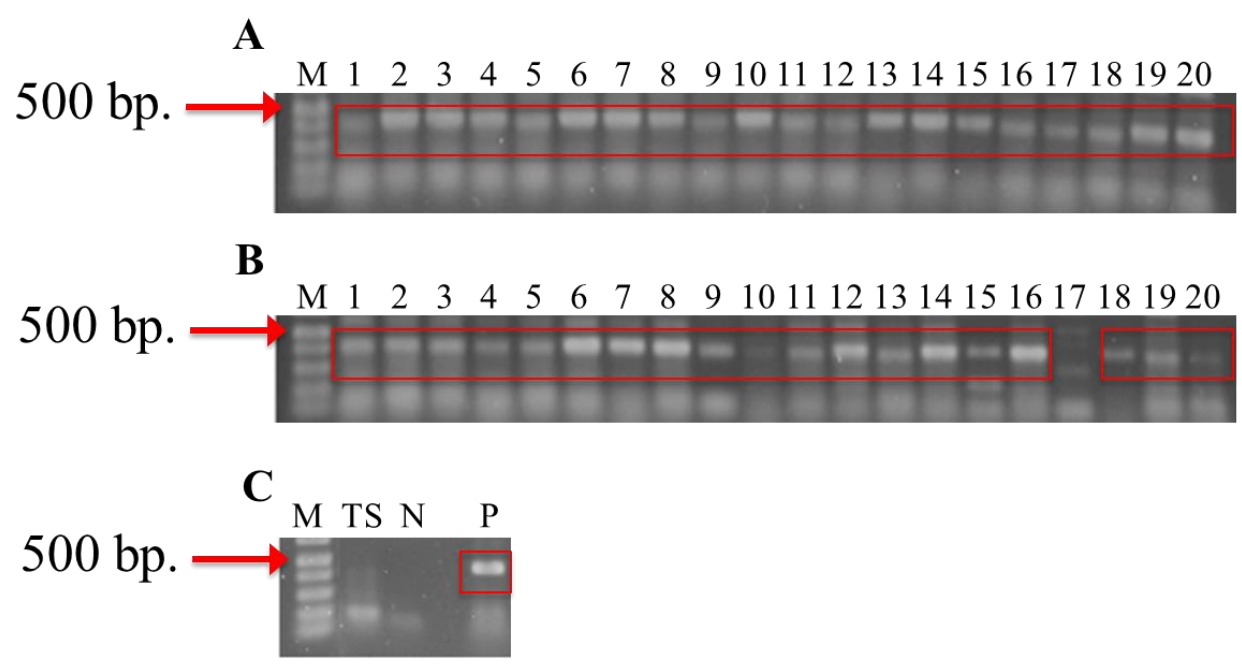

Figura 13: Géis de agarose a 1\% mostrando resultados de RT-PCR com o par de primers STV3 para amostras de tomateiro coletadas em Brazlândia. (A) amostras da cultivar Serato; (B) amostras da cultivar BRS Zamir; e (C) tomate sadio - TS, negativo - N e positivo - P. Os fragmentos esperados foram de 440 pares de bases e estão marcados dentro de caixas vermelhas. $\mathrm{M}=1 \mathrm{~Kb}$ plus (Invitrogen).

A menor incidência por região foi de zero por cento, nas quatorze amostras de Patos de Minas, e a maior foi de $100 \%$ nas três amostras de Morrinhos. As amostras de São José do Rio Preto, de Reserva, de Corumbá de Goiás, Taquara e Goianápolis exibiram incidências de 
$23 \%, 48 \%, 67 \%, 75 \%$ e $75 \%$, respectivamente (Tabela 5). Não houve amplificação nos controles negativos.

Tabela 5: Resultados obtidos na detecção de STV por RT-PCR com os pares de primers STVm e STV3, para as amostras de tomateiro coletadas em diferentes campos de produção, mostrando a quantidade de amostras positivas e amostras testadas, a incidência do vírus no local de origem e a(s) cultivar(es) coletadas.

\begin{tabular}{|c|c|c|c|c|c|}
\hline Origem & Cultivar(es) & $\begin{array}{c}\text { Pos./test. } \\
\text { por } \\
\text { cultivar }\end{array}$ & $\begin{array}{c}\text { Incid. por } \\
\text { cultivar } \\
(\%)\end{array}$ & $\begin{array}{c}\text { Pos./test. } \\
\text { por } \\
\text { região }\end{array}$ & $\begin{array}{c}\text { Incid. } \\
\text { por } \\
\text { região } \\
(\%)\end{array}$ \\
\hline Patos de Minas (MG) & Desconhecida & - & - & $0 / 14$ & 0 \\
\hline \multirow{2}{*}{ São José do Rio Preto (SP) } & Ravena & $1 / 4$ & 25 & \multirow{2}{*}{$2 / 9$} & \multirow{2}{*}{23} \\
\hline & Tyna & $1 / 5$ & 20 & & \\
\hline Reserva (PR) & Desconhecida & - & - & $11 / 23$ & 48 \\
\hline \multirow{2}{*}{ Corumbá de Goiás (GO) } & Itaipava & $1 / 3$ & 67 & \multirow{2}{*}{$4 / 6$} & \multirow{2}{*}{67} \\
\hline & Compac & $3 / 3$ & 100 & & \\
\hline \multirow{3}{*}{ Taquara (DF) } & Trucker & $6 / 9$ & 67 & \multirow{3}{*}{$18 / 24$} & \multirow{3}{*}{75} \\
\hline & Júpiter & $5 / 6$ & 84 & & \\
\hline & Marguerita & $7 / 9$ & 78 & & \\
\hline Goianápolis (GO) & Desconhecida & - & - & $6 / 8$ & 75 \\
\hline \multirow{2}{*}{ Brazlândia (DF) } & Serato & $20 / 20$ & 100 & \multirow{2}{*}{$39 / 40$} & \multirow{2}{*}{98} \\
\hline & BRS Zamir & $19 / 20$ & 98 & & \\
\hline Morrinhos (GO) & Desconhecida & - & - & $3 / 3$ & 100 \\
\hline
\end{tabular}

Dentre as amostras nas quais a cultivar foi registrada, Tyna (São José do Rio Preto) apresentou a menor incidência de STV (20\%), enquanto as cultivares Compac e Serato coletadas em Corumbá de Goiás e Brazlândia, respectivamente, apresentaram 100\% de incidência. As demais cultivares: Ravena, Itaipava, Trucker, Júpiter, Marguerita e BRS Zamir apresentaram $25 \%, 67 \%, 67 \%, 84 \%, 78 \%$ e $98 \%$ de plantas infectadas respectivamente. 


\section{Detecção de STV em plântulas}

As plântulas de tomateiro das cultivares BRS Sena, Santa Clara, Predador, H-9553 e H9992 foram coletadas com 10 dias de idade para extração de RNA e detecção de STV por RTPCR (Figura 1). O par de primers STVm foi utilizado para a diagnose do STV neste ensaio. Tomateiro sadio, àgua Milli-Q tratada com DEPC e o clone p-GEM-T Easy-STV 440 DF foram utilizados como controles.
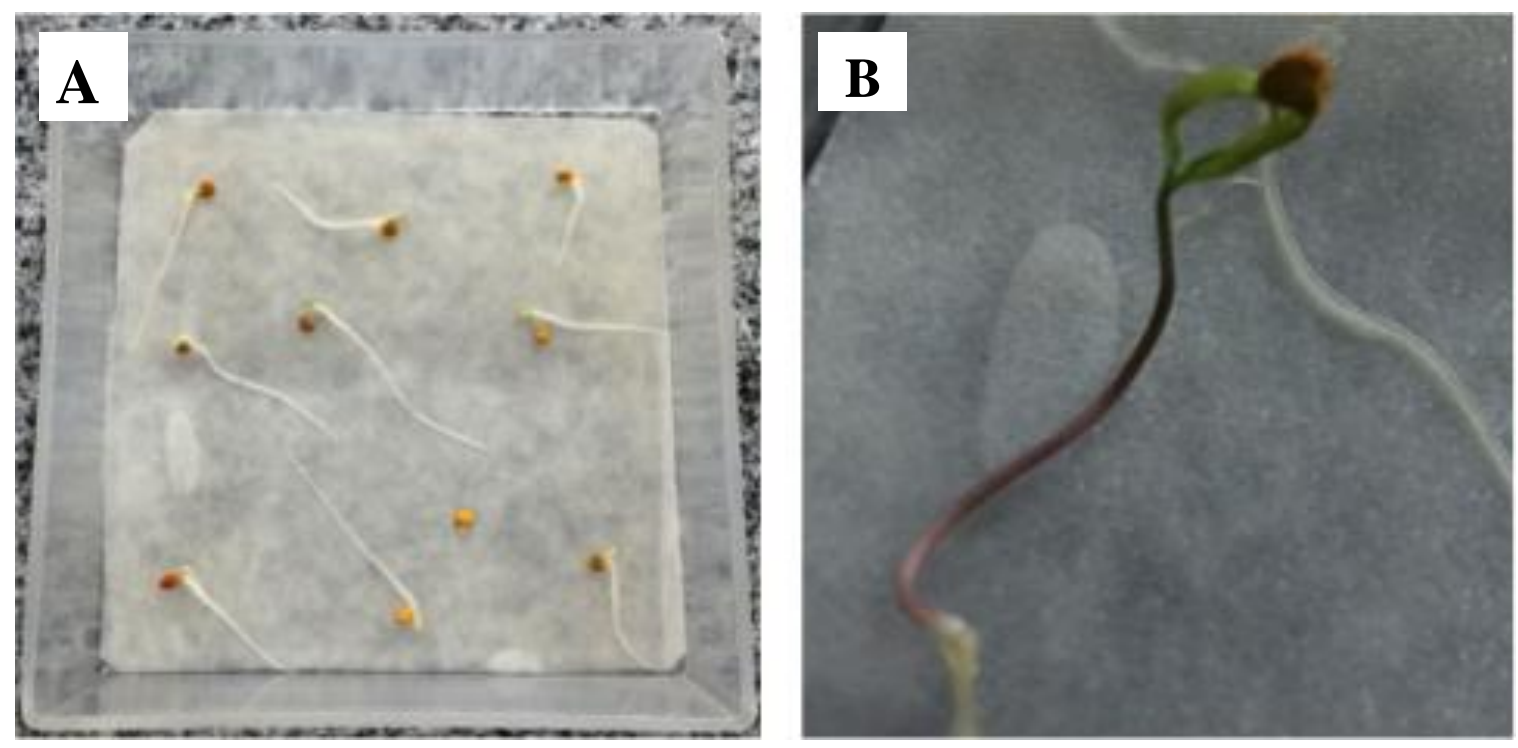

Figura 14: (A) Foto de plântulas da cultivar BRS Sena com quatro dias de idade, sob papel filtro umedecido com água destilada, em recipiente plástico transparente; (B) Foto de plântula da cultivar BRS Sena com 10 dias de idade.

A cultivar BRS Sena não apresentou plântulas positivas para detecção de STV, enquanto a cultivar Predador apresentou todas as plântulas testadas infectadas com o vírus. A incidência nas cultivares H-9553, H-9992 e Santa Clara foi de 9\%, 44\% e 18\% respectivamente (Tabela 6). A detecção do STV nas plântulas confirmou a presença do vírus em sementes de tomateiro comercializados no Brasil e no mundo. 
Tabela 6: Resultados obtidos na detecção de STV por RT-PCR com par de primers STVm para as cultivares BRS Sena, H-9553, H-9992, Santa Clara.

\begin{tabular}{ccc}
\hline Cultivar & Positivas/testadas & $\begin{array}{c}\text { Taxa de } \\
\text { detecção }(\%)\end{array}$ \\
\hline BRS Sena & $0 / 23$ & 0 \\
H-9553 & $2 / 23$ & 9 \\
Santa Clara & $3 / 17$ & 18 \\
H-9992 & $7 / 16$ & 44 \\
Predador & $11 / 11$ & 100 \\
\hline
\end{tabular}

\section{DISCUSSÃO}

As doenças representam o maior desafio enfrentado pelos produtores de tomate, pois são responsáveis por significativas perdas na produção (do Vale et al., 2013). Os vírus provocam inúmeras dessas doenças, sendo que normalmente uma alta incidência de viroses é registrada em épocas propícias à disseminação dos vetores. Não existem produtos químicos com capacidade de restabelecer a sanidade de uma planta após a infecção viral, logo, as estratégias mais efetivas de controle são baseadas no princípio da exclusão, com a prevenção da entrada do vírus na lavoura (Kimati et al., 2011).

O princípio da exclusão foi estabelecido por Whetzel em 1925 e as medidas de controle baseadas nesse princípio são praticadas através de medidas quarentenárias, consolidadas em legislações fitossanitárias promulgadas por órgãos governamentais, nacionais e internacionais. No Brasil, embora o Ministério da Agricultura, Pecúaria e Abastecimento (MAPA) publique portarias para disciplinar a importação de diferentes espécies vegetais, as facilidades dos meios de transporte modernos e o aumento de trânsito e intercâmbio internacional tornam as medidas de exclusão cada vez mais vulneráveis (Marinho et al., 2007; Kimati et al., 2011).

Considerando os riscos de entrada de patógenos, a importação de sementes e mudas é regulamentada pela Instrução Normativa $n^{0} 06$, de 16 de maio de 2005, que estabelece a prévia avaliação da veiculação de pragas dos materiais importados destinados à multiplicação 
ou propagação vegetal, por laboratórios de diagnóstico fitossanitário ou quarentena (MAPA, 2005; da Silva, 2013).

A detecção de STV por RT-PCR nas amostras originais analisadas por NGS e em amostras coletadas em outros estados confirmaram a presença do STV no Brasil. A organização genômica do STV é semelhante a dos totivírus, composta por único segmento contendo duas ORFs sobrepostas parcialmente e com mesmo mecanismo de expressão da RNA polimerase (frameshifting ribossomal) (Tzanetakis \& Sabanadzovic, 2013). A família Partitiviridae inclui vírus de RNA fita dupla que infectam fungos e plantas. Seu genoma é composto por dois segmentos, que codificam a RNA polimerase (dsRNA1) e a proteína de revestimento (dsRNA2) (Ghabrial et al., 2011). Contudo, as análises filogenéticas desse trabalho e de trabalhos anteriores indicam que os amalgavírus estão mais próximos dos partitivírus que dos totivírus (Figura 12) (Sabanadzovic et al., 2009; Sabanadzovic et al., 2010; Martin et al., 2011).

A análise filogenética de STV também confirmou a alta proximidade filogenética entre os isolados encontrados com diversos isolados de outros países. As sequências desse vírus são muito próximas, de forma que impossibilita a verificação de qualquer diferença evolutiva entre eles. Essa proximidade e a prevalência da transmissão por sementes nessa espécie indicam uma provável introdução do vírus no país através de sementes importadas.

A transmissão por sementes é um meio eficaz de introdução de vírus em um cultivo em fase inicial, pois se formam diversos focos de infecção primária em todo o plantio. Quando outro tipo de transmissão dissemina o vírus na cultura em desenvolvimento, a transmissão por semente torna-se de importância econômica (Hull, 2002). Cerca de um sétimo dos vírus vegetais conhecidos são transmitidos por sementes de pelo menos uma espécie vegetal que ele infecta. A persistência desses vírus nas sementes por longos períodos favorece sua disseminação a longas distâncias (Hull, 2002; Sanches \& Krause-Sakate, 2013). 
A possibilidade de existência de vírus no material vegetal introduzido no país por sementes é menor em comparação às demais unidades de propagação vegetativa como tubérculos, bulbos e plântulas, porém a extensão da transmissão do vírus pela semente depende da estirpe viral, do vírus e da planta hospedeira (Wang \& Maule, 1994; Johanse et al., 1994; Sanches \& Krause-Sakate, 2013). No caso do STV, a taxa de transmissão vertical em tomateiro é comumente alta, variando de acordo com a cultivar (Sabanadzovic et al., 2009).

Na importação de vegetais e suas partes, a Análise de Risco de Pragas (ARP) apresentase como a primeira linha de defesa para a segurança fitossanitária nacional, porém, a grande quantidade de importadores interessados provoca a incapacidade operacional do governo em realizar as ARPs com a celeridade necessária (da Silva, 2013). Em 2005, a Instrução Normativa.$^{\circ}$ 06, de 16 de maio, liberou os produtos que já haviam sido importados pelo menos uma vez desde 12 de agosto de 1997 da realização da ARP (MAPA, 2005). Essa medida deu origem a seção destinada à consulta de Produtos Vegetais de Importação Autorizada (PVIA), mantida pelo MAPA em sua página na web (da Silva, 2013).

Cerca de 50\% das autorizações que constam na lista de PVIA referem-se a sementes de diversas espécies e origens, sendo que a espécie Solanum lycopersicum é a que tem mais origens autorizadas. Quatorze países exportam sementes de tomate para o Brasil sem ARP: China, França, Alemanha, Itália, dentre outros (da Silva, 2013).

A intensificação do comércio internacional e a desatenção com as medidas fitossanitárias aumentam o risco de trânsito de pragas e patógenos entre as nações (de Almeida, 2013). Alguns exemplos de vírus transmitidos por sementes de tomate, ausentes no país e presentes em países que exportam sementes para o Brasil sem a realização da ARP são: o Pepino mosaic virus - PepMV, o Pelargonium zonate spot virus - PZSV e o Tobacco rattle virus - TRV (da Silva, 2013). Esses vírus estão na lista de pragas quarentenárias do MAPA, 
ou seja, são vírus não relatados no país até o momento, que tem o potencial de causar danos significativos às espécies agrícolas cultivadas caso sejam introduzidos (MAPA, 2007). Além disso, o PepMV e o PZSV são espécies virais consideradas emergentes para a cultura do tomate por serem vírus originários de outras culturas que mudaram de nicho e passaram a infectar o tomateiro, e sua incidência registrada nesse novo nicho vem aumentando a cada dia (Hanssen et al., 2010).

Infecções mistas e a impossibilidade de transmissão mecânica ou por vetores inviabilizaram o estudo da sintomatologia do STV. O vírus foi detectado em tomateiros assintomáticos de Brazlândia (Cultivares Serato e BRS Zamir) em alta incidência (100\% e 98\%, respectivamente). Sua detecção em plantas assintomáticas sugere uma infecção latente. A principal motivação para o estudo dos vírus vegetais é a patogênese causada nas plantas, logo, o sucesso das pesquisas com vírus que causam doenças em culturas ofuscam o fato de que as infecções virais de plantas frequentemente são assintomáticas (Fraile \& García-Arenal, 2016). O modo de transmissão de um vírus é um dos fatores que favorecem ou prejudicam a evolução de genótipos patogênicos. A aptidão de vírus transmitidos verticalmente depende do potencial reprodutivo do hospedeiro, que gera novos indivíduos para serem infectados. Sendo assim, esses vírus evoluem no sentido de menor virulência para maximizar sua própria aptidão (Fraile \& García-Arenal, 2016).

Embora os estudos sobre a relação entre a virulência e o modo de transmissão sejam escassos, a correlação negativa entre a virulência e a transmissão vertical foi demonstrada em alguns trabalhos (Fraile \& García-Arenal, 2016). Um exemplo foi o experimento realizado com Cucumber mosaic virus - CMV em Arabdopsis thaliana, que demonstrou a associação entre o aumento das taxas de transmissão vertical e a redução da virulência (Pagán et al., 2014). 
A evolução da virulência pode ser determinada pelas taxas relativas de transmissão vertical e horizontal (Fraile \& García-Arenal, 2016). No caso do STV, a prevalência do modo de transmissão vertical em altas taxas e a inexistência de um modo de transmissão horizontal podem ter contribuido para a evolução de um genótipo de baixa virulência e assintomático.

A proporção de progênie infectada por vírus (taxa de transmissão vertical) normalmente apresenta-se baixa (Lima, 2015), porém o STV foi relatado com elevadas taxas de transmissão vertical (Sabanadzovic et al., 2009). Neste trabalho, a taxa de detecção do vírus a partir de plântulas de sementes variou de acordo com a cultivar testada, porém mesmo a menor taxa (9\% na cultivar H-9553) é considerada elevada.

A presença do STV em tomateiros coletados em diversos campos de produção do país e em plântulas de sementes de variedades comerciais mostra a extensa distribuição desse vírus principalmente nas regiões Sudeste e Centro-Oeste que foram aqui avaliadas, e nas sementes comerciais frequentemente utilizadas pelo produtor brasileiro. Até o momento, esse quadro não se mostra preocupante devido à provável ausência de sintomas e de mecanismos de transmissão horizontal que possam levar a evolução de estirpes virais patogênicas, porém, isso demonstra a fragilidade à qual está submetido o controle do material vegetal importado pelo país. Embora a importação de sementes seja essencial para a economia brasileira, esses materiais exigem maior atenção das autoridades fitossanitárias, pois o não cumprimento de medidas fitossanitárias realizadas para autorizar a entrada desses materiais pode trazer consequências devastadoras para a agricultura do país. 


\section{CONCLUSÕES}

A presença do STV em diversos campos de produção de tomate do país e em plântulas de sementes de variedades comerciais mostra a extensa distribuição desse vírus nas lavouras do país e nas sementes comerciais comumente utilizadas pelo produtor.

A prevalência da transmissão vertical em altas taxas e a inexistência de um modo de transmissão horizontal podem ter contribuido para a evolução de genótipos assintomáticos de STV. A detecção do vírus em amostras assintomáticas reforça a hipótese da sua condição latente em tomateiro.

As análises filogenéticas demonstraram a alta proximidade das sequências dos isolados brasileiros com isolados provenientes de outros países, o que impossibilita a verificação de qualquer diferença evolutiva entre eles.

As altas taxas de transmissão vertical de STV sugerem a sua introdução no país a partir da importação de sementes. A extensa distribuição do STV não se mostra preocupante até o momento devido à provável ausência de sintomas e de mecanismos de transmissão horizontal que possam levar à evolução de estirpes virais patogênicas. O relato de sua presença no país demonstra a fragilidade à qual está submetido o controle do material vegetal importado.

O não cumprimento de medidas fitossanitárias que visem à análise das sementes autorizadas a importação pode trazer consequências desastrosas para o agronegócio. 


\section{LITERATURA CITADA}

BATISTA, M.F. \& MARINHO, V.L. A. 2002. Vírus e Viróides Transmitidos por Sementes. $1^{a}$ edição. Embrapa Recursos Genéticos e Biotecnologia. Brasília, DF.

CANDRESSE, T.; MARAIS, A. \& FAURE, C. 2013. First report of Southern tomato virus on tomatoes in Southwest France. Plant Disease 97: 1124.

DA SILVA, A.F.C.P. 2013. A fiscalização do comércio de sementes e mudas como ferramenta de prevenção e controle de pragas dos vegetais. Dissertação de Mestrado. Universidade Federal de Viçosa. Minas Gerais, Brasil.

DO VALE, F.X.R.; LOPES, C.A. \& ALVARENGA, M.A.R. 2013. Doenças fúngicas, bacterianas e causadas por nematoides. In: ALVARENGA, M.A.R. Tomate: produção em campo, casa de vegetação e hidroponia. $2^{\text {a }}$ ed. Universidade de Lavras. Lavras. p. 275-277.

FELSENSTEIN, J. 1985. Confidence limits on phylogenies: An approach using the bootstrap. Evolution 39: 783-791.

FRAILE, A. \& GARCÍA-ARENAL, F. 2016. Environment and evolution modulate plant virus pathogenesis. Current opinion in virology 17: 50-56.

GHABRIAL, S.A.; NIBERT, M.L.; MAISS, E.; LESKER, T.; BAKER, T.S. \& TAO, Y.J. 2005. Family Partitiviridae. In: KING, A.; LEFKOWITZ, E.; ADAMS, M. J.; CARSTENS, E. B. Virus Taxonomy: Ninth Report of the International Committee on Taxonomy of Viruses. Elsevier Academic Press, San Diego, Califórnia. p. 523-534.

HANSSEN, I.M.; LAPIDOT, M., \& THOMMA, B.P. 2010. Emerging viral diseases of tomato crops. Molecular plant-microbe interactions 23(5): 539-548.

IACONO, G; HERNANDEZ-LLOPIS, D.; ALFARO-FERNANDEZ, A.; DAVINO, M.; FONT, M.I.; PANNO, S.; GALIPIENSO, L.; RUBIO, L. \& DAVINO, S. 2015. First report of Southern tomato virus in tomato crops in Italy. New disease reports 32: 27.

INOUE-NAGATA, A.K. 2013. Doenças viróticas. In: ALVARENGA, M.A.R. Tomate: produção em campo, casa de vegetação e hidroponia. $2^{\mathrm{a}}$ ed. Universidade de Lavras. Lavras. p. 327-344.

JOHANSEN, E.; EDWARDS, M.C. \& HAMPTON, R.O. 1994. Seed Transmission of Viruses: Current Perspectives. Annual Review of Phytopathology 32: 363-386

KIMATI, H.; BERGAMIN FILHO, A.; AMORIM, L. 2011. Controle de doenças. In: AMORIM, L.; REZENDE, J.A.M. \& BERGAMIN FILHO, A. Manual de Fitopatologia: princípios e conceitos. $4^{\mathrm{a}}$ edição. Agronômica Ceres. São Paulo, SP. p. 
306-323.

KUMAR S.; STECHER G. \& TAMURA K. 2016. MEGA7: Molecular Evolutionary Genetics Analysis version 7.0 for bigger datasets. Molecular Biology and Evolution 33: 1870-1874.

MAPA. 2005. Instrução Normativa $n^{0}$ 06, de 16 de maio de 2005. BRASIL. http://sistemasweb.agricultura.gov.br/sislegis/action/detalhaAto.do?method=visualizarA toPortalMapa\&chave $=1123856005$. Acesso em 5 de agosto de 2016 .

MAPA. 2007. Instrução Normativa $n^{\circ}$ 52, de 20 de novembro de 2007. BRASIL. http://extranet.agricultura.gov.br/sislegis-consulta/consultarLegislacao.do?operacao=vi sualizar\&id=18212. Acesso em 5 de agosto de 2016.

MARINHO, V.L.A.; MENDES, M.A.S.; CARLOS, M. \& TENENTE, R.C.V. 2007. Intercâmbio e quarentena de germoplasma vegetal no período de 2004 à 2007. Concórdia: Embrapa Recursos Genéticos e Biotecnologia, 8 p. (Comunicado técnico, 158).

MARTIN, R.R.; ZHOU, J. \& TZANETAKIS, I.E. 2011. Blueberry latent virus: an amalgam of the Partitiviridae and Totiviridae. Virus research 155(1): 175-180.

NCBI. 2016. Open reading frame finder. NCBI. https://www.ncbi.nlm.nih.gov/orffinder/. Acesso em fevereiro de 2016.

PADMANABHAN, C.; ZHENG, Y.; LI, R.; FEI, Z. \& LING, K. 2015b. Complete genome sequence of Southern tomato virus naturally infecting tomatoes in Bangladesh. Genome Announcements 3(6): e01522-15.

PADMANABHAN, C.; ZHENG, Y.; LI, R.; SUN, S.; ZHANG, D.; LIU, Y.; FEI, Z. \& LING, K. 2015. Complete genome sequence of Southern tomato virus identified in China using next generation sequencing. Genome Announcements 3(5): e01226-15.

PAGÁN, I.; MONTES, N.; MILGROOM, M.G. \& GARCÍA-ARENAL, F. 2014. Vertical transmission selects for reduced virulence in a plant virus and for increased resistance in the host. PLoS Pathogens 10(7): e1004293.

SABANADZOVIC, S.; GHANEM-SABANADZOVIC, N.A. \& VALVERDE, R.A. 2010. A novel monopartite dsRNA virus from rhododendron. Archives of virology 155(11): 1859-1863.

SABANADZOVIC, S.; VALVERDE, R.A.; BROWN, J.K.; MARTIN, R.R.; TZANETAKIS, I.E. 2009. Southern tomato virus: the link between the families Totiviridae and Partitiviridae. Virus Research 140: 130-137.

SANCHES, M.M.; KRAUSE-SAKATE, R. 2013. Análises para vírus, viroides e fitoplasmas 
em material vegetal importado. Concórdia: Embrapa Recursos Genéticos e Biotecnologia, Brasília - DF, 31 p. (Documentos, 344).

TAMURA K. 1992. Estimation of the number of nucleotide substitutions when there are strong transition-transversion and $\mathrm{G}+\mathrm{C}$-content biases. Molecular Biology and Evolution 9: 678-687.

TZANETAKIS, I.E. \& SABANADZOVIC, S. 2013. Establishment of the family Amalgaviridae, the genus Amalgavirus and inclusion of four species in the genus. ICTV. http://www.ictvonline.org/proposals/2013.005a-gP.A.v2.Amalgaviridae.pdf. Acesso em 25 de junho de 2016.

VERBEEK, M.; DULLEMANS, A.M.; ESPINO, A.; BOTELLA, M.; ALFAROFERNÁNDEZ, A. \& FONT, M.I. 2015. First report of Southern tomato virus in tomato in the Canary Islands, Spain. J Plant Pathol 97:392.

WANG, W.; MAULE, A. 1994. A Model for Seed Transmission of a Plant Virus: Genetic and Structural Analyses of Pea Embryo lnvasion by Pea Seed-Borne Mosaic Virus. The Plant Cell 6: 777-787.

WANG, Z.; GERSTEIN, M. \& SNYDER, M. 2009. RNA-Seq: A revolutionary tool for transcriptomics. Nature Reviews Genetics 10: 57-63, 2009. 


\section{CONCLUSÕES GERAIS}

O sequenciamento de alto desempenho mostrou-se uma ferramenta útil para a detecção de vírus de RNA e DNA que comumente são encontrados em lavouras de tomateiro brasileiras. Adicionalmente, essa técnica permitiu a detecção de um vírus ainda não relatado em tomateiro, o PMMoV, e dois vírus do gênero Ilarvirus: Ageratum latent virus e Parietaria mottle virus, que levantaram suspeitas de existência de uma nova espécie. Foi possível também a primeira detecção do STV em tomateiro no Brasil e a montagem de dois genomas de STV, um de Brazlândia e um de Minas Gerais. As sequências genômicas dos isolados de STV brasileiros compartilham de alta identidade de nucleotídeos com as demais sequências de STV disponíveis. Foi possível confirmar a presença de STV em tomateiros de lavouras das regiões Sudeste e Centro-Oeste, e em sementes comerciais. As altas taxas de transmissão vertical sugerem a introdução desse vírus no país através da importação de sementes. Até o momento, a presença do vírus não parece ser preocupante devido à provável ausência de sintomas e de mecanismos de transmissão horizontal que possam levar a evolução de estirpes virais patogênicas. A detecção do STV em tomateiro demonstra a fragilidade à qual está submetido o controle do material vegetal importado pelo país e a necessidade de medidas fitossanitárias rigorosas que visem à análise das sementes autorizadas à importação, para evitar futuras consequências desastrosas para a agricultura nacional. 